\title{
Integrated Solid Waste Management in Japan
}

CSI Resource Systems, Incorporated

Boston, Massachusetts

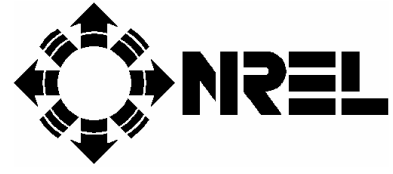

National Renewable Energy Laboratory 1617 Cole Boulevard

Golden, Colorado 80401-3393

Operated by Midwest Research Institute for the U.S. Department of Energy

Under contract No. DE-AC02-83CH10093 


\section{Integrated Solid Waste Management in Japan}

CSI Resource Systems, Incorporated

Boston, Massachusetts

NREL Technical Monitor: Philip B. Shepherd

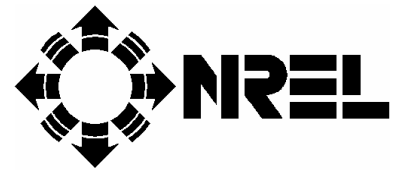

National Renewable Energy Laboratory 1617 Cole Boulevard Golden, Colorado 80401-3393

A national laboratory operated by Midwest Research Institute for the U.S. Department of Energy under contract No. DE-AC02-83CH10093

Prepared under Subcontract No. HZ-2-12028-3

October 1993 


\section{NOTICE}

NOTICE: This report was prepared as an account of work sponsored by an agency of the United States government. Neither the United States government nor any agency thereof, nor any of their employees, makes any warranty, express or implied, or assumes any legal liability or responsibility for the accuracy. completeness, or usefulness of any information, apparatus, product, or process disclosed, or represents that its use would not iniringe privately owned rights. Reference herein to any specific commercial product. process. or service by trade name, trademark. manufacturer, or othenwise does not necessarily constitute or imply its endorsement, recommendation, or favoring by the United States government or any agency thereof. The views and opinions of authors expressed herein do not necessarily state or retlect those of the United States government or any agency thereof.

Printed in the United States of America

Avaitable from:

National Technical Information Service

U.S. Department of Commerce

5285 Port Royal Road

Spring field, VA $2216 t$

Price: Microfiche A01

Printed Copy A07

Codes are used for pricing all publications. The code is determined by the number of pages in the publication. Information pertaining to the pricing codes can be lound in the current issue of the following publications which are generally available in most libraries: Energy Research Abstracts (ERA); Government Reponts Announcements and index (GRA and I); Scientific and Technical Abstract Reports (STAR); and publication NTIS-PR-360 available from NTIS at the above address. 


\section{ACKNOWLEDGEMENTS}

A study of this nature could not have been conducted without the participation of a large number of individuals and organizations. To those listed below, CSI Resource Systems, Incorporated extends its sincere thanks and appreciation.

We are especially grateful to Dr. James Abert for assisting us in making arrangements for the trip to Japan and for accompanying CSI's Dr. Alan Cohen on the trip. The many contacts and friends Dr. Abert had made in Japan while a Fulbright Research Scholar were particularly useful to us in performing this study. Recommendations for the trip itinerary were also made by Mr. Atsuhiko Sano of the Community Policy Institute of Yokaham, Japan, and by Mr. Kunihiro Nakazato of Takuma Co., Ltd., of Osaka, Japan. $\mathrm{Mr}$. Nakazato, based in New York City, and his company were particularly helpful in arranging for plant tours and numerous meetings in osaka, Fukuoka, and Omiya.

Interpretation services were provided in Japan by Ms. Myumi Yorizumi and Ms. Takato of the Community Policy Institute, and by Mr. Takaichi of Takuma Co., Ltd. We are especially grateful for the hospitality extended to Dr. Cohen by Mr. Takaichi and Takuma Co. Translation services were provided by Mr. Carl Kay, Ms. Laura Silverman, Ms. Chiharu Nobeoka, and Ms. Karen Yahara of the Japanese Language Service of Boston. These services were invaluable to properly conducting a study of this nature.

The many men and women in Japan who gave of their time and expertise to assist us in this study are listed in Appendix A of this report. Mr. Koki Asuma, Section Chief of the Japanese Ministry of Health and Welfare, reviewed a draft version of Sections 2 and 3 of this report. His willingness to conduct this review helped to ensure the accuracy of the information provided.

We would also like to thank Ms. Constance Hornig, also a former Fulbright Scholar in Japan, for the many hours of informative discussions she had with us about the history, culture, and integrated "gomi" management practices of the Japanese people.

Funding for this effort was provided by the U.S. Department of Energy (DOE) through the National Renewable Energy Laboratory (NREL). Our thanks to Messrs. Donald Walter and Simon Friedrich of DOE and Messrs. Bimleshwar Gupta and Phillip Shepherd of NREL for their support of this project. 


\section{CONTENTS}

Page

EXECUTIVE SUMMARY

1. BACKGROUND AND INTRODUCTION

1.1 JAPAN: BACKGROUND 18

1.2 UNDERSTANDING SOLID WASTE MANAGEMENT IN JAPAN

1.3 JAPAN AS "BENCHMARK" FOR U.S. RECYCLING PROGRAM GOALS 22

1.4 REPORT ORGANIZATION

2. ENVIRONMENTAL REGULATORY STRUCTURE 26

2.1 HISTORICAL OVERVIEW 26

2.2 ENVIRONMENTAL LAWS AFFECTING SOLID WASTE MANAGEMENT

3. NATIONAL WASTE GENERATION, TREATMENT, AND

DISPOSAL STATISTICS

3.1 MUNICIPAL SOLID WASTE GENERATION, COLLECTION, AND TREATMENT

3.2 PRIVATE-SECTOR RECYCLING

3.3 ESTIMATED TOTAL DISCARDS AND RECYCLING RATES

3.4 MUNICIPAL SOLID WASTE MANAGEMENT COSTS

$\begin{array}{ll}\text { 4. CASE STUDIES } & 77\end{array}$

4.1 FUKUOKA CITY

4.2 MATSUDO CITY

$\begin{array}{lll}4.3 & \text { HIRATSUKA CITY } & 108\end{array}$

5. SUMMARY OF FINDINGS 121

APPENDIX A: Meetings and Tours Conducted in Japan

B: Glossary of Terms

C: Metric Conversion Factors

D: Comparison of Population Densities: Selected U.S. and Japanese Cities 


\section{INTEGRATED SOL. ID WASTE MANAGEMENT IN JAPAN}

\section{EXECUTIVE SUMMARY}

The Japanese, through a combination of public policy, private market conditions, and geographic necessity, practice integrated municipal solid waste (MSW) management, defined in the U.S. EPA's Decision-Makers' Guide to Solid Waste Management as:

A practice of using several alternative waste management techniques to manage and dispose of specific components of the municipal solid waste stream. Waste management alternatives include source reduction, recycling, composting, energy recovery, and landfilling.

The Japanese Ministry of Health and Welfare (MHW) publishes a number of guidelines to assist municipalities in the implementation of their MSW management programs. The Guidelines of Solid Waste Management, published by the MHW in the late 1970 s, provides the planning requirements and minimum technical specifications for waste treatment facilities (i.e., facilities to separate, combust, compost, shred, bail, and/or physically, chemically, or biologically change the refuse until it is suited for recycling or landfill disposal). The approach of MSW management in Japan as stated in these guidelines is as follows:

The basic concept of refuse treatment consists of recycling discharged refuse into usable resources, reusing such resources as much as possible, and then treating or disposing of the unusable portion into a sanitary condition. Considering the difficulty of procuring land or seaside areas for such purpose as a refuse disposal site, it will be necessary to minimize the volume of refuse collected for treatment or disposal.

This approach clearly incorporates waste reduction, reuse and recycling, combustion, and disposal, and thus represents integrated solid waste management.

The Japanese have not defined a specific hierarchical preference for these waste management options. However, in marked contrast to the U.S. approach, the Japanese system relies heavily on waste combustion with or without energy recovery. Specifically, the MHW's guidelines state:

Among the various treatments methods, incineration permits the highest reduction of volume while at the same time stabilizing putrefactive organic matter. In general, therefore, combustible refuse will principally be burned and then finally disposed of.

Current policy still emphasizes incineration/waste-to-energy as a primary means of treating MSW. For example, the Annual Report on Health and Welfare 1990-1991, states: 
MSW volume can be slashed by crushing [shredding] or compressing to some extent, but reduced substantially by incineration in terms of weight and cubic volume. Therefore, planned construction of or improvements in incineration facilities must be encouraged... reusable waste such as iron and aiuminum are encouraged to be collected even [during] midstage treatment such as crushing and incineration to the extent possible.

The Japanese heavy reliance on incineration/waste-to-energy can be explained primarily by the country's severe shortage of 7 andfill space and the Japanese desire to sanitize and sterilize the waste.

National and local Japanese governments are now more actively participating in and promoting recycling, as exemplified by the $199 \mathrm{I}$ passage of the Law for Promotion of Utilization of Recyclable Resources (the "Recycling Law") and the 1991 amendment to the Waste Disposal and Public Cleansing Law (the "Waste Disposal Law"). This has been due 1 argely to the rapid increase (approximately 3.6 percent annually) in waste generation since 1985. It is also due to the yen's appreciation, which has made imported virgin materials less costly, resulting in a decrease in the relative value of secondary materials.

\section{ENVIRONMENTAL LAWS AFFECTING SOLID WASTE MANAGEMENT}

The environmental movement in Japan during the late 1960 s and early 1970s, was similar to the movement that occurred in the United States during the same time period. The Basic Law for Environmental Pollution Control (the "Basic Law"), which took effect in August 1967, required that the Japanese national government develop environmental quality standards and promulgate regulations to meet these standards in order to protect public health and the natural environment. Local governments were given the responsibility of enforcing these regulations.

The 1970 Diet (which became known as the "Anti-Pollution Diet"), passed new environmental legislation and strengthened existing environmental control laws, including the Basic Law. The Anti-Pollution Diet also strengthened the power of local governments to promulgate standards and regulations that are more stringent than those of the national government. The Japanese Environmental Agency (JEA) was established in 1971 for the express purpose of promoting the protection of the environment and coordinating the activities of all other administrative agencies dealing with environmental protection.

The Basic Law provides the framework for pollution control, including solid waste management. Within this framework, a number of other 1 aws were enacted to protect the environment. The principal law affecting solid waste disposal is the Waste Disposal Law, which was enacted by the Anti-Pollution Diet in 1970 and became effective in September 1971. The Waste Disposal Law was amended in 1974, 1976, 1983, and 1991. The Recycling Law became effective in October 1991 . 
Pollution-prevention laws affecting solid waste management include the Air Pollution Control Law, the Water Pollution Control Law, the Noise Control Law, the Vibration Control Law, and the Offensive Odor Control Law. Ocean dumping of waste and incineration of wastes on ships or marine facilities are regulated by the Law for the Prevention of Marine Pollution and Maritime Disaster, while the use of sea-area land as disposal and processing sites is regulated under the Law for the Arrangement of Regional Coastal Environment Centers.

The Air Pollution Control Law regulates emissions of sulfur oxides, particulate matter, hydrogen chloride, and nitrogen oxides emitted from MSW combustion facilities.

The Japanese government has not promulgated any regulations governing the control of dioxins and furans from the combustion of MSW or the disposal of the resultant ash. Rather, after the completion of a five-year study (1985 through 1990) of the mechanism of formation and degradation of dioxins, the Ministry of Health and Welfare issued a set of guidelines for MSW combustion and ash disposal. These guidelines differ according to the various types of incinerators employed in Japan (i.e., continuous combustion, semi-continuous combustion, mechanical-batch combustion, and fixed-grate batch combustion), and according to whether a facility is new or existing.

The guidelines for ash disposal take into account the low solubility of dioxins and furans in water and their high adsorptivity to soils, and suggest that leachate treatment to prevent solids discharges and the use of daily cover at the landfill are adequate to control the slight traces of dioxins and furans in the ash residue.

The Japanese have not promulgated any regulations for the control of heavy metal emissions. Many local communities attempt to reduce mercury emissions by separating, at the source, materials that contain mercury, such as thermometers, dry cell batteries, and fluorescent light bulbs.

The Water Pollution Control Law controls effluent discharges from combustion and processing facilities. Leachate from landfills is regulated by the Waste Disposal Law; however, the effluent standards are the same as those established pursuant to the Water Pollution Control Law.

The Recycling Law outlines the general responsibilities of governments, businesses, and consumers in promoting the use of recycled materials. Japan's national, prefecturai, and municipal governments are responsible for helping to secure funding, promoting research and development, and developing public awareness campaigns. Businesses are encouraged to increase their use of secondary materials and to promote post-consumer and manufacturing by-product recycling. Consumers are to cooperate with the actions taken by the government and businesses to promote recyciing.

Unlike many communities in the Unites States that have established recycling goals, utilization goals that have been established in Japan are material-specific, including the recycling of manufacturing by-products as 
well as post-consumer products, and reflect the usage of secondary materials in the manufacturing process. In particular, the Recycling Law establishes the following recycling goals: a waste paper utilization rate of 55 percent by fiscal year 1994 (from 48 percent in 1988); a steel can utilization rate of 60 percent by fiscal year 1995 (from 44 percent in 1989); an aluminum can utilization rate of 60 percent by fiscal year 1994 (from 43 percent in 1989); and a glass cullet utilization rate of 55 percent by fiscal year 1995 (from 49 percent in 1988).

Solid waste management in Japan, including collection, recycing, processing, and disposal, is implemented in accordance with the Waste Disposal Law, which the Ministry of Health and Welfare (MHW) is responsible for administering.

Waste is categorized as either Industrial Waste or General Waste. Industrial Wastes are those generated by business and industrial activities and either specifjcally defined within the Waste Disposal Law or determined by Cabinet Order. General Waste includes all wastes not defined as Industrial Waste and is essentialiy residential waste and wastes that are similar to residential waste but generated by businesses, institutions, and industry. The 1991 amendment to the Waste Disposal Law created a subcategory, Specially Managed Wastes, for both Industrial and General Waste. Specially Managed Wastes are those that require special treatment or disposal because they are hazardous, explosive, toxic, infectious, or in other ways possibly detrimental to human health or the environment.

The Waste Disposal Law provides for the financial support of municipalities, including subsidies for the construction of wasteprocessing and disposal facilities. The level of support is determined by Cabinet Order. Currently it is 25 percent of the eligible construction costs of incinerators, waste-to-energy facilities, bulky waste shredders, materials recovery facilities, and landfills. For municipalities designated as having severe pollution problems, the subsidy can be as high as 50 percent of the eligible construction costs. The national government is also responsible for providing assistance in the financing of these facilities.

An amendment to the Waste Disposal Law was passed in October 1991. The purpose of the amendment is to promote waste reduction and recycling; improve waste collection, transport, processing, and disposal activities; and ensure the development and construction of needed waste-processing and disposal capacity.

The Waste Disposal Law also specifies the standards for 1 andfills, including their design, operation, and maintenance. Wastes that are permitted to be disposed of by ocean dumping are defined in the Waste Disposal Law, while the ocean-disposal methods and the areas within the ocean where dumping is permitted are governed by the Prevention of Marine Pollution and Maritime Disaster Law. Ocean dumping in Japan is treated on an exception basis when there are problems with a particular landfill. All types of General Waste may be disposed of in a 1andfill, however, Specially Managed Wastes are subject to pre-treatment such as combustion or shredding. 
General Tandfill standards exist for General, Industrial, and hazardous wastes. Individual standards are established for each site and type of waste, such as sludge, cinders, and ash. The standards are established to prevent pollution of groundwater and public waterways; to reduce the volume of waste ultimately requiring disposal; to stabilize the properties of the waste; and to prevent the occurrence of sanitation problems.

Landfills used for the disposal of General Waste must be designed with an impervious liner and a leachate collection and treatment system. Uni ined landfills without leachate collection systems are allowed for stable industrial wastes such as plastics, rubber scrap, metal scrap, waste glass and ceramics, and demolition waste.

Conducting environmental impact assessments for large projects and employing best available control technologies is generally practiced in Japan by custom rather than through 1 aw.

\section{MUNICIPAL SOLID WASTE GENERATION, COLLECTION, AND TREATMENT}

"Discards," as the term is used in this report, refers to all materials considered used and spent by residential and commercial generators. That which is discarded (whether recyclable or nonrecyclable) and treated either directly or indirectly (i.e., through municipal-private agreements) by a municipality is referred to in Japan, and in this report, as municipal solid waste (MSW). Such treatment can include municipal recycling, landfilling, combustion (with or without energy recovery), and composting. Discards that are diverted from the municipal solid waste stream (and therefore not considered MSW) are so diverted through private recycling efforts (e.g., "group recycling," recycling dealers, garage sales, flea markets, returns to retail outlets, donations, etc.). Group recycling, considered a private fund-raising activity, is increasingly being subsidized by municipalities. However, in cases where such subsidization occurs, group recycling is nevertheless considered private, rather than municipal, recycling. Municipal recycling is the recovery of recyclable MSW and can occur through source-separation programs, mixedwaste processing, materials recovery centers, or post-combustion materials recovery. Therefore, when "MSW treatment" is discussed in this report, it does not include discarded materials that have not entered the waste stream.

Each year the MHW publishes comprehensive national statistics on MSW generation and the treatment methods extant in Japan. The information in these documents is compiled from data reported by municipalities which together represent 99.9 percent of Japan's population. The information presented below was obtained from the annual MHW report published in December 1991 and reflects data compiled from Apri1 1, 1989, through March 31 , 1990, i.e., Japanese fiscal year 1989 (FY89). This MHW report exclusively addresses MSW, i.e., discards treated by municipal governments. 


\section{MSW Generation}

During FY89, 48.7 million metric tonnes (53.6 million tons) of MSW were generated in Japan. This tonnage does not include discarded materials that were diverted from the waste stream for reuse or recycling; nor does it include the approximately 1.3 million tonnes that were reported to have been disposed of directly by individuals (e.g., disposed of down kitchen sinks, burned, buried, or composted in backyards). This does, however, include materials separated from MSW for reuse or recycling by municipalities after collection.

\section{MSW Treatment}

of the 48.7 million tonnes of MSW treated by Japanese municipalities in FY89, approximately 74 percent was combusted with and without energy recovery, 23 percent was sent to landfill, 3 percent was municipally recycled, and approximately 0.1 percent was composted or used as animal feed. This breakdown clearly evidences Japan's national palicy of combusting the combustible fraction of the MSW stream, which was begun in the 1970s.

The residues from MSW processing and combustion were eventually sent, along with noncombustible waste, to landfills for disposal. In total, approximately 17 million tonnes, or 35 percent, of the MSW treated by municipalities was 7 andfilled. Because of combusting, shredding, and compacting, the MSW volume reduction is significantly greater than its weight reduction.

Bulky, noncombustible, and source-separated MSW are processed to recover reusable and recyclable materials such as ferrous metals, aluminum, glass, newspapers, magazines, corrugated cartons, clothing, furniture, and appliances. Of the $48.7 \mathrm{million}$ tonnes of MSW treated by municipalities in FY89, only 1.5 million tonnes, or 3.1 percent of these materials, were recovered from the MSW stream for reuse or recycling. As indicated previously, municipally sponsored recycling reflects only a fraction of a11 the recycling that occurs in Japan.

\section{PRIVATE-SECTOR RECYCLING}

In the U.S., recycling is typically conducted through municipal recycling programs; hence, Americans tend to think of recycling as a municipal function. However, this is not the case in Japan, where the bulk of recycling occurs through private-sector endeavors.

Historically, there has been a strong private market for secondary goods such as old newspapers, magazines (including the telephone-book-sized "comic books" that are very popular in Japan), corrugated cartons, stee1, aluminum, textiles (e.g., used clothing for sale in other, less developed Pacific rim countries), and glass. There are many ways by which such materials are privately collected, including returning reusable glass bottles to stores or distributors, group recycling, and private recycling dealers (often referred to in the U.S. as junk dealers or scavengers). 
Many products (primarily beer, sake, and liquor, and to a lesser extent milk and soy sauce) are sold in reusable glass bottles. A relatively large number of bottles are recycled each year in Japan. The Clean Japan Center reports that 80.5 percent of refillable bottles was returned in 1989. The high rate of return of these bottles occurs in part because many of the products sold in these bottles are distributed in large quantities to restaurants, hotels, and bars, from which the empty bottles are picked up by the distributor. Similarly, many liquor stores and some milk companies make deliveries to households and pick up the empty bottles in the process.

The private market for secondary goods is supported by volunteer organizations that raise money for the community (e.g., local PTA organizations raising money for school activities) by establishing collection points, i.e., drop-off centers, for community residents to bring secondary materials to for recycling. The volunteer organizations have agreements with private recycling dealers to pick up these materials at predetermined times, and the recyciling dealers pay these organizations for the materials received. Often a recycling dealer only collects specific materials; therefore, it is common to have many dealers working with a given volunteer organization. This type of recycling is known in Japan as "group recycling". Recycling dealers also collect recyclable materials directly from households and commercial establishments.

Japan does not have many vehicles comparable to the U.S.'s Salvation Army or Goodwill Industries; thrift, resale, and consignment shops; garage and estate sales; and flea markets by which to divert clothing, furniture, appliances, kitchenware, and other household discards from the MSW stream. In part, these types of resale outlets are not very prevalent in Japan because the Japanese have a greater aversion to using second-hand goods than do Americans. The national government and many municipalities are, however, promoting such ideas as using goods longer; giving usable but unwanted goods to others; and holding "garage sales," flea markets, or bazaars as ways to increase the recycling of discards. Japanese officials often cite the success of such U.S. programs in their educational materials promoting these kinds of activities.

\section{ESTIMATED TOTAL DISCARDS AND RECYCLING RATES}

Because the mechanisms for recycling previously discussed are carried out by citizens and private businesses, statistics on the total quantity of discards diverted from the MSW stream are not generated by local or national governments. However, a number of studies designed to estimate the total quantity and types of discards (i.e., MSW and privately recycled discards) have been conducted in Japan. Three such studies were conducted in the mid-1980s: one of the Meguro Ward of Tokyo, one of Okayama City, and one of Matsudo City. Each of these studies estimated the amount of private-sector recycling from both residential and commercial sources. 
These studies may overstate the rates of private-sector recycing that occur in these communities. The rates may be high because many of the participants in the studies were municipal employees or members of civic groups and because "in comparison with the average household, many households in the survey are making an effort to reduce and recycle properly." The bias of the survey technique is somewhat counterbalanced by the recent municipal and national government programs to promote recycling. Therefore, the results of these studies provide reasonable estimates of recycling rates in Japan today.

The 1986 estimated percentages, or levels, of private-sector recycing, exclusive of self-disposed waste, determined by these studies are 18.2 percent in the Meguro Ward, 12.7 percent in Okayama, and 25.7 percent in Matsudo.

According to the MHW data, Japan generated $48.7 \mathrm{mill}$ ion tonnes of MSW in FY89. If it is assumed that the above private-sector recycling rates are representative of Japan as a whole, and if the assumed nationwide range of 12.7 to 25.7 percent is applied to the MHW's FY89 MSW generation figure, the resultant range of total discards (exclusive of self-disposed waste) generated in Japan during FY89 is 55.7 to 65.5 million tonnes (61.3 to 72.1 million tons). Based on this data, the total rate of combined municipal and private-sector recycling of both residential and commercial discards in Japan (exclusive of self-disposed wastes) is estimated to range from 15 to 28 percent.

of the estimated 55.7 to 65.5 million tonnes of residential and commercial discards generated in Japan during FY89, exclusive of self-disposed waste, an estimated 55 to 64 percent was combusted; 15 to 28 percent was recycled (onty 2 to 3 percent through municipal recycling activities); and 17 to 20 percent was landfilled. Including ash disposal, 26 to 30 percent, by weight, of the gross discards were landfilled.

\section{CASE STUDIES}

In-depth case studies of the integrated municipal solid waste management (IMSWM) systems of three Japanese communities (Fukuoka City, Matsudo City, and Hiratsuka City) were performed as part of this report. The case studies provide examples, albeit not an exhaustive study, of various approaches to municipal solid waste management in large, medium, and small cities in Japan.

\section{Fukuoka City}

Fukuoka City had a 1991 population of 1.2 million people, making it the largest city on Kyushu, the southern- and western-most of the four main islands of Japan. Located on the northern coast of Kyushu, Fukuoka City is the island's center of trade and commerce. With a land area of 336 square kilometers, Fukuoka City's population density is approximately 3,500 persons per square kilometer (9,190 persons per square mile). 
As is typical of many cities in Japan, particularly large cities, Fukuoka City residents only separate their MSW into combustible and noncombustible fractions. Bulky wastes are also collected, separately. In FY9l, just over 74 percent of the MSH collected from residences was separated as combustible waste, which includes kitchen waste, paper, paper diapers, fibers, wood, straw, some plastics, and leather. The balance was noncombustible waste (which includes steel and aluminum cans, other metal discards, glass bottles and other breakables, some plastics, rubber, sand, and ashes), and bulky waste (e.g., furniture, appliances). Almost 78 percent of the MSW generated by both residential and commercial sources and treated by the City was classified as combustible waste.

In FY91, Fukuoka city treated 713,107 tonnes of MSW. of this amount, 36,106 tonnes were imported from three neighboring municipalities: Kasuga, Hisayama, and Nakagawa, which have an aggregate population of 134,000 people. The FY91 annual per capita MSW generation rate for Fukuoka City, exclusive of these other communities, was 0.54 tonnes per person (i.e., about 3.3 pounds per person per day).

Fukuoka City's IMSWM system consists of three waste-to-energy facilities; three bulky-waste shredding facilities (located at each of the three waste-to-energy faci]ity sites); a mixed-waste shredding and materials recovery facility; and two landfills.

of the 713,107 tonnes treated by the City in FY91, approximately 82 percent was combusted, which is well above the national average of 74 percent. About 51,000 tonnes, or 7.2 percent, of the MSW was processed through the bulky shredders at the mixed waste shredding and materials recovery center known as the Eastern Crushing Disposal Center. of this amount, almost 60 percent was recovered as combustible material, while almost 18 percent was recovered as saleable ferrous and aluminum metals. This represents a municipal recycling rate from Fukuoka City-treated MSW of only 1.3 percent, which is well below the national average municipal recycling rate of 3.1 percent.

About 110,000 tonnes or, 15 percent, of the MSW was sent directly to the landfills. including the 103,000 tonnes of ash generated at the three waste-to-energy facilities and the 12,400 tonnes of residue from the Eastern Crushing Disposal Facility, about 32 percent, by weight, of the MSW was landfilled. Since almost half of the material landfilled consisted of combustion ash, the volume reduction was significantly greater than the weight reduction of the MSW.

Fukuoka City is illustrative of the approximately 80 percent of municipalities in Japan that do not collect source-separated recyclables. Many of these communities rely on mechanical recovery of recyclable materials through systems similar to the one employed in Fukuoka City.

These communities rely heavily on combustion for volume reduction and sanitization of the MSW. Mixed-waste processing can further reduce the volume of material going to landfills, through the recovery and recyciling of metals and the recovery and combustion of combustible material that was improperly sorted by the waste generators. 
Matsudo City

Incorporated in 1943, Matsudo City is located in northwest Chiba Prefecture, about $20 \mathrm{kilometers} \mathrm{northeast} \mathrm{of} \mathrm{Tokyo.} \mathrm{The} \mathrm{City} \mathrm{had} \mathrm{an} \mathrm{FY90}$ population of about 450,000 , which represents a 6.7 percent increase since 1985. Its population density is about 7,300 persons per kilometer $(19,000$ persons per square mile). Matsudo City has instituted a source-separation recycling program and actively supports private-sector recyciing through subsidy payments to group recyclers and price-support payments to recycling dealers.

Matsudo City requires its residents to separate their MSW into five categories: combustible waste, noncombustible waste, recyclable materials, bulky waste, and household hazardous waste. Combustible waste includes food waste, yard waste, paper, chopsticks, paper diapers, and cooking oil. Noncombustible waste includes some plastic and rubber products (e.g., vinyl, polystyrene, nylon), pottery, shells, leather, and relatively small tatami mats and rugs. Recyclables include newspapers, magazines, clothes, glass bottles, steel and aluminum cans, bicycles, and appliances (including television sets, washing machines, and refrigerators). The household hazardous wastes are those that contain mercury, such as dry cell batteries, thermometers, and fluorescent lights.

The City does not provide door-to-door collection of separated residential MSW. Rather, MSW is deposited by residents at about 7,100 stations Tocated throughout the city. This represents about one station per 20 households. The various classifications of waste are collected on different days. Combustible waste is collected three times a week, noncombustibles two times a week, and recyclables and household hazardous wastes once a week. The household hazardous wastes are placed in specially labeled plastic bags. Bulky waste can be delivered to municipal treatment facilities directly or be picked up by the city upon request. There was a total of 294 collection days during Fy90.

During FY90, Matsudo City treated 142,231 tonnes of MSW. Matsudo City's MSW-processing system consists of two waste-to-energy facilities, two noncombustible and bulky waste shredding facilities, and a materials recovery facility. The household hazardous wastes are temporarily stored at the MRF and eventually shipped to the Nomuka Kyosan mine in Hokkaido, where they are stored and treated.

In FY90, 17,093 tonnes of recyclable material (exclusive of materials from City-supported group recycling activities) were delivered to the materials recovery facility known as the Resource Recycling Center. Of that amount, 13,017 tonnes (76.2 percent) were recovered for sale or reuse; 54 tonnes ( 0.3 percent) were combusted; and 4,022 tonnes (23.5 percent) of the material collected as recyclables became residue and was eventually landfilled.

Noncombustible and bulky wastes were either sent directly to the 1 andfill or were shredded at the City's second shredding and compacting facility, which is located near the Resource Recycling Center. The compacted waste 
was then transported to a landfill located outside of Matsudo City. Including 13,750 tonnes of combustion ash, a total of 34,294 tonnes of waste was landfilled in FY90. This is 24 percent, by weight, of the MSW treated by the city.

Matsudo City has one of the more mature and successful municipal recycling programs in Japan. It consists of once-a-week collection, at approximately 7,100 stations, of recyclable materials; operation of the Resource Recycling Center MRF; shredding of noncombustible and bulky waste and magnetic recovery of ferrous metals; support for over 270 volunteer recycling groups; and material price supports for recycling dealers. Exclusive of the group recycling activities, in FY90 the City recovered 13,017 tonnes of recyclable MSW, or 9.2 percent of total MSW, which is well above the national average municipal recycling rate of 3.1 percent. An additional 2,334 tonnes of discards were recovered through citysponsored group recycling. Combined, these activities resulted in 10.6 percent of the sum of the MSW treated by the city and the discards collected through city-sponsored group recycling being recovered as saleable materials.

Another important component of the City's recycling program is its support of private recycling dealers. Traditionally, these dealers collected used goods, paid individuals or groups for the material they collected, and made a profit from the resale of these materials. However, as market values decreased for many of the materials, the profitability of collecting them decreased; as a result, more of this material found its way into the MSW stream.

Recognizing the value to the city of diverting these materials, Matsudo City has established a price-support mechanism to maintain the profitability of diverting certain materials during weak market conditions. For example, in 0ctober 1992 the City was paying the recycling dealers for each kilogram of ferrous metals diverted from the waste stream.

Municipalities in Japan have extensive information about the MSW they must treat, but very little data on the amount of material that is diverted from the waste stream by residents and businesses. In addition, the effectiveness of private recycling efforts is not known.

In the mid-1980s, Matsudo City hired 0strand, Inc., LTD. to help the City prepare its plan for the treatment of General Waste. The 0strand scope of work included designing and conducting surveys of households and businesses within the City to identify the mechanisms used to divert discards, and to estimate the quantity and types of discards so diverted.

By combining the 0strand and City FY90 data estimates of total discards, the per-capita generation rate and recycling rates can be estimated for FY90. The quantity of total MSW treated by Matsudo City in FY90 was 142,000 tonnes, of which 102,800 tonnes were from residences. Muttiplying the quantity of residential MSW by 1.29 (the ratio of total discards, excluding self-disposed discards, to residential MSW, as determined by the 
Ostrand study) results in an estimated 133,000 tonnes of residential discards. Similarly, multiplying the balance of MSW treated by the City by 2.59 (the ratio of total discards, exclusive of self-disposed discards, to commercial MSW treated by the City) results in an estimated 102,000 tonnes of commercial discards. The estimated FY90 quantity of total discards is 235,000 tonnes. The FY90 annual per-capita generation rate for the 450,000 persons living in Matsudo City was 0.52 tonnes per person (i.e., 3.1 pounds per person per day).

Commercial establishments indicated that about 28 percent of their discards are exported to other cities. This large percentage of exports reflects the fact that Matsudo City has limited landfill capacity and therefore also exports most of its MSW and ash requiring landfilling to locations outside its jurisdiction.

The total estimated recycling rate within Matsudo City in FY90 was 31 percent. It is particulariy interesting that over 80 percent of the material recovered for recycling consisted of paper (primarily newspaper, magazines, and cardboard), glass beverage containers (reusable bottles and cullet), and metals (ferrous and aluminum). These are the same types of materials typically included in recycling programs in the U.S. The success of the recycling program in Matsudo city can be attributed to the high capture rates of these materials and the relatively high concentrations of these materials in the total discards.

About 20 percent of the recovered materials were reusable bottles, which illustrates the impact on recycling of Japan's deposit system. Over 72 percent of these bottles were recovered from commercial establishments such as restaurants, bars, and hotels.

The 0strand study provides a unique opportunity to estimate the Fy90 quantity of total discards generated in Matsudo City and the methods used to manage the City's total MSW stream. Of the total discards, an estimated 46 percent was combusted; 31 percent was recycled; less than 0.01 percent was treated as household hazardous waste; and 23 percent, exclusive of ash, was landfilled.

\section{Hiratsuka City}

Hiratsuka City is one of 37 municipalities in the Kanagawa Prefecture, the largest of which is Yokohama City. With a 1990 population of about 244,000 persons and a population density of about 3,590 persons per square kilometer (or about 9,310 persons per square mile), Hiratsuka city is considered a small- to medium-sized urbanized city.

The "Hiratsuka Method" of increasing the amount of discards recovered from households for recycling is well known in Japan. Recognizing the benefits of group recycling, the City began to subsidize group recycling activities in 1977. The Hiratsuka Method refers to the direct payment by the City to group recyclers for the materials they divert from the waste stream. In 1983 the City established a committee to study the program and make 
suggestions to improve its effectiveness. In 1983 the City began pilot programs of what has become the "New Hiratsuka Method, "which was fully implemented in 1986 .

The original Hiratsuka Method required recycling groups to register with the City. Such groups could be citizens councils, PTAs, children's groups, senior citizen clubs, or other civic organizations. Each group determined a suitable location for the collection station in its neighborhood and was responsible for providing supervisors during collection days. The collection days and times were determined through negotiations with each group and the recycling dealers. The groups would then inform the city of the collection days and times. The dealers paid the City the market price they would have paid the groups without the City involvement, and the city in turn paid the groups a flat subsidy of 8 yen per kilogram of each material recovered. In essence, the City purchased the material from the citizens groups for a flat guaranteed fee and then sold the material to the recycling dealers at market prices, which on average were usually below the price paid to the groups.

The original Hiratsuka Method was viewed as being inefficient because only registered groups participated and collections occurred irregularly or, at best, once every two months. As a result, participation was not Citywide, and because of storage limitations, many potential recyclables were discarded in the more frequent collections of combustible (twice a week) and noncombustible (twice a month) waste.

The New Hiratsuka Method collects source-separated recyclables twice a month on a specified schedule. Furthermore, the stations used as collection points for combustible and noncombustible waste were also established as permanent locations for the group recycling collections, although such collections are not conducted on the same day. Each station services about 50 families, and all residents of the city can now participate in the program.

The night before each scheduled recyclable material collection day, the City supplies and places containers at each station. Sufficient wire mesh and stackable containers are provided to allow the citizens to segregate, at the station, reusable bottles, color-sorted broken bottles and other glass containers, steel cans, aluminum cans, and other ferrous and nonferrous discards. Newspapers, magazines, milk cartons (cleaned and cut open), and clothing must be neatly tied or bundled and placed in designated areas next to the containers.

Citizens' Councils elect representatives to supervise the stations during recyclable material collection days. The supervisors make sure that the material is properly sorted and that the area stays neat and clean. Toward the end of the day, City -designated recycling dealers pick up the recovered material. More than one dealer may come to each station to pick up specific types of materials. Finally, at the end of the day the city workers pick up any discards that were not recyclable and were left behind, pick up any empty containers, and clean the site. 
The heart of the Hiratsuka Method is still the 8-yen payment per kilogram of material diverted by the recycling groups. Groups no longer need to register with the City. Rather, all payments are made to the Citizens' Councils, which control most of the private organizations in the city. Although the city still receives payments from the recycling dealers, during times of poor market conditions, the City now provides a pricesupport subsidy to the dealers. The relatively high subsidy to the recycling groups and the price supports to the recycling dealers result in high participation rates and provide stability to the system, particularly when markets for the recovered goods are poor.

The Hiratsuka Method for recovering recyclable materials from residences has been quite successful. This approach enhanced the private recycling activities that were prevalent in Hiratsuka City by fixing collection times and locations; providing subsidies to civic groups and price supports to recycling dealers; and organizing the collections by the recycling dealers. By doing so, the City has almost tripied the amount of material collected by the groups it supports. Unfortunately, data is not available to determine how much material was actually diverted from the MSW stream or from private recycling activities not supported by the city.

The success of the Hiratsuka Method is apparent in that of the approximately 91,400 tonnes of discards managed by the City in FY90, 17 percent was recovered for recycling: approximately 16 percent $(14,200$ tonnes) of it through the Hiratsuka Method. Eighty percent of the approximately 91,400 tonnes of discards was combusted. Ferrous was recovered from the combustion ash, and bulky waste and noncombustibles were shredded and classifjed to recovered ferrous and aluminum (as well as combustibles). This post-processing recovered ferrous and aluminum made up by the remaining approximately 2 percent (1,650 tonnes) of the 17 percent of discards recovered for recycling.

\section{SUMMARY OF FINDINGS}

Highlighted below are some of the salient findings of this study.

1. The underlying principal governing municipal solid waste management policy in Japan is the conservation of limited landfill capacity through minimization of the volume of municipal solid waste requiring landfilling. Even though Japan has limited supplies of natural resources, its recycling efforts are driven by the need for volume reduction moreso than by the desire for materials reuse or remanufacture.

2. The environmental movement in Japan during the late 1960 s was similar to the movement that occurred in the U.S. during that same time period. Comprehensive air pollution control, water pollution control, and solid waste management laws were promulgated to protect public health and the environment. An amendment to the primary solid waste disposal 1 aw and a new recycling law were passed in 1991. 
3. Conducting environmental impact assessments for large projects and employing best available control technologies is generally practiced in Japan by custom rather than through 1 aw.

4. After completion of a five-year study (1988 through 1990) of the mechanisms of formation and degradation of dioxins, the Japanese Ministry of Health and Welfare issued a set of guidelines for MSW combustion and ash disposal rather then promulgating any emission or combustion control regulations.

5. The Japanese national government has not promulgated any regulations to control heavy metal emissions from the combustion of MSW. Many local communities attempt to reduce mercury emissions by separating, at the source, materials that contain mercury, such as thermometers, dry-cell batteries, and fluorescent Tight buTbs.

6. Japanese municipalities often subsidize private recycling activities to increase their effectiveness and, more recently, given the decrease in market demand for recycled materials, to maintain their existence.

7. The Japanese national government provides subsidies for the construction of municipal solid waste management facilities. Such subsidies are used to implement nationally mandated environmental controls.

8. The Japanese Ministry of Health and Welfare considers combustion the most effective means of reducing the volume of and sanitizing municipal solid waste.

9. Of the nearly 49 million tonnes of MSW (which, by definition, refers to only those discards treated by municipalities) treated during Japan's Fiscal Year 1989 (i.e., April 1, 1989, through March 31, 1990), approximately:

- 74 percent was combusted with or without energy recovery;

- 23 percent was Tandfilled (exclusive of ash);

- 3 percent was municipally recycled; and

- less than $1 / 10$ of one percent was composted. (The number of composting facilities has remained relatively constant over the past five years.)

10. Many discards are diverted from the MSW stream through private recycling activities and are not included in national waste generation statistics. The Japanese, in fact, refer to such diverted discards as "that which would have become waste but did 
not." Accounting for all discards, an estimated 55.7 to 65.5 million tonnes of residential and commercial discards were generated in Japan during FY89. Of this amount, an estimated:

- 55 to 64 percent was combusted, with and without energy recovery;

- 17 to 20 percent was landfilled (exclusive of ash); and

- $\quad 15$ to 28 percent was recycled. 


\section{INTEGRATED SOLID WASTE MANAGEMENT IN JAPAN}

Japan, a country with precious little land area to devote to burying waste, has long employed additional means of municipal solid waste management. It depends heavily on combustion facilities (with and without energy recovery) to reduce the volume of municipal solid waste requiring landfill disposal. Recycling is also widespread throughout Japan, motivated by the need to preserve the country's 1 imited 1 andfill capacity. As the U.S. has moved toward an integrated approach to municipal solid waste management rather than reliance on a single method, it has begun to look to other, more experienced countries such as Japan to provide models for structuring integrated systems.

In the interest of determining what roles recycling, composting, waste-toenergy, and landfilling play in Japan's integrated municipal solid waste management systems, and in the interest of clarifying Japan's methods of recycling and their actual effectiveness, the purpose of this study was to evaluate Japan's integrated municipal solid waste management systems, giving special attention to, and performing close analysis of, its recycling activities. In addition, this study focused on the environmental regulatory setting within which these solid waste management activities are conducted. The history of the environmental movement that arose in Japan and the specific 1 aws and regulations affecting Japanese solid waste management were thoroughly reviewed to allow a full understanding of municipal solid waste management practices in Japan and a comparison with those extant in the U.S.

As a major component of conducting this study, Dr. A1 an S. Cohen, of CSI Resource Systems, Incorporated (CSI), visited Japan for a two-week period in October 1992. Dr. James G. Abert of Georgetown University accompanied Dr. Cohen during the first week of the trip. While there, Dr. Cohen conducted meetings with many individuals (including national and local Japanese government officials; paper, steel can, aluminum can, and glass bottle association staff members; Clean Japan Center staff members; waste management plant operators; and solid waste management consultants and scholars). Interpreters were provided in Japan by the Community Policy Institute of Yokohama, Japan, and Takuma Co., Ltd., of Osaka, Japan, to facilitate communications. A listing of the individuals and organizations contacted by Dr. Cohen is provided in Appendix A of this report. Specific solid waste management facilities throughout Japan were visited and their operations observed, and in-depth case studies of municipal solid waste management in three Japanese municipalities (Fukuoka City, Matsudo City, and Hiratsuka Cjty) were performed. In addition, CSI conducted an extensive review of pertinent literature. Translations of documents published in Japanese were provided by the Japanese Language Service of Boston. 


\subsection{JAPAN: BACKGROUND}

A brief summary of Japan's geographics and demographics, average annual worker-household income and expenditures, and political structure is given below to provide a contextual basis for the body of this report. The information presented is taken largely from the Statistical Handbook of Japan, 1992 and the Japan Local Government Data Book, 1991.

\subsubsection{Geographics/Demographics}

Japan stretches along the northeastern coast of Asia and consists of four main islands: Hokkaido, Honshu, Shikoku, and Kyushu (see Figure 1-1) and over 6,800 smaller islands, which have a combined total land area of about 377,700 square kilometers (approximately 145,800 square miles). Japan is roughly equal in area to France or Italy or about $1 / 25$ th the area of the United States. Of this area, only 27 percent is flat enough to be arable and habitable. The remaining area is mountainous and suitable only for mining, forestry, and generating hydroeletric power. Thus, Japan's nearly 123 milition inhabitants (about half the population of the U.S.) live and work on about 102,000 square kilometers (about 39,400 square miles) of 1 and, yielding an effective population density of 1,210 persons per square kilometer $(3,140$ persons per square mile). The Japanese population is expected to increase moderately over the next two decades, with a projected population of 129 million persons expected by the year 2010 .

Japan's movement fram an agricultural to an industrial economy has resulted in 43.6 percent of its population living within a 50-kilometer (about 19-mile) radius of the center of Tokyo, Osaka, or Nagoya. The population densities of these three metropolitan areas are significantly higher than those of other areas of Japan; they were $3,831,2,183$, and 1,150 persons per square kilometer (approximately 9,930, 5,660, and 2,980 persons per square mile), respectively, in 1990.

\subsubsection{Average Annual Income and Expenditures}

The average annual income per worker-household (i.e., households headed by individuals who work in offices, factories, stores, government offices, schools, etc.) was approximately 6.3 million yen (about $\$ 46,600$ ) in 1990 . of this amount, approximately 16 percent was spent on taxes, social security, and other non-consumption expenditures. Almost 64 percent of annual income was spent on goods and services in 1990. Twenty-four percent of this was spent on food; 14 percent was spent on housing, utilities, and furnishings; 10 percent was spent on transportation and communications; 9.6 percent was spent on reading material and recreation; 7.2 percent was spent on clothing; 5.1 percent was spent on education; 2.5 percent was spent on medical expenses; and the balance was spent on miscellaneous expenditures. In 1990, almost 21 percent of average workerhousehold income was saved or retained. 


\section{FIGURE 1-1}

\section{MAP OF JAPAN}

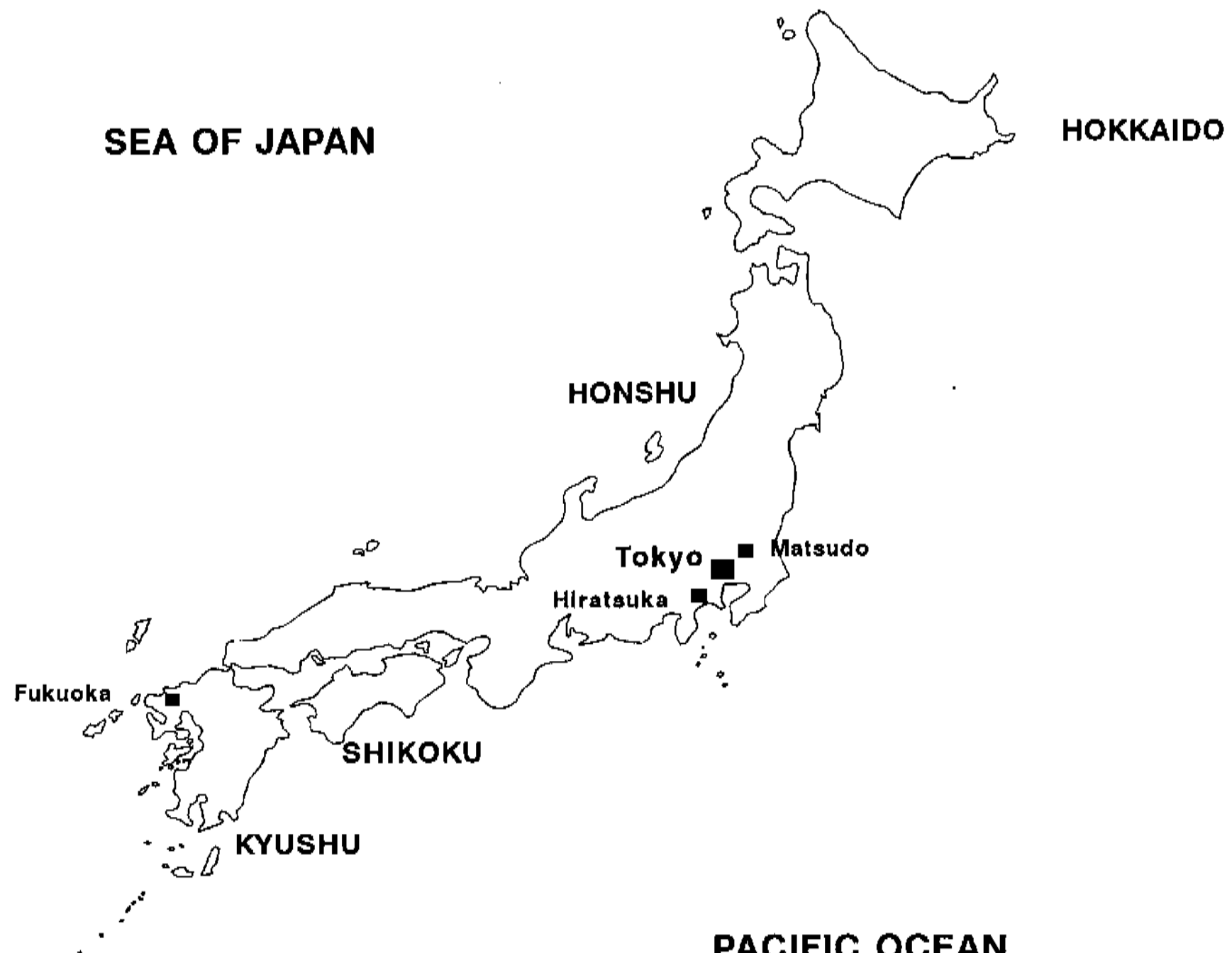

PACIFIC OCEAN 
Almost every household in Japan has a refrigerator, color television set, and washing machine, while about 80 percent of households own a personal automobile. In every year since 1983, pubtic opinion polls have identified "having more leisure time" as the number-one personat need of the Japanese people.

\subsubsection{Governmental Structure}

Pursuant to the Japanese Constitution, adopted in 1947 , sovereignty rests with the people through a Parliamentary Cabinet system of government. All men and women over the age of 20 are eligible to vote. The national government comprises the judicial, legislative, and executive branches, as depicted in Figure 1-2.

The judicial branch is independent of the executive and legislative branches of government. The court system consists of the Supreme court, eight high courts, 50 district courts, 50 family courts, and 452 summary courts.

The legislature, referred to as the Diet, is composed of the House of Representatives, which has 512 seats, and the House of Councillors, which has 252 seats. In 1992, eight political parties held seats in the Diet; however, the Liberal Democratic Party held 54 percent and 45 percent of the seats in the House of Representatives and the House of Councillors, respectively. The Liberal Democratic Party has been in power since 1948 .

The executive branch is headed by the Prime Minister and 12 Ministers of State, together referred to as the Cabinet. The Prime Minister is appointed by a resolution of the Diet, while the Ministers of State are chosen by the Prime Minister. The Prime Minister and the majority of the Ministers of State are chosen from among the members of the Diet.

There are two levels of local government: prefectures, which are similar to states in the U.S., and municipalities. As of January 1992, there were 47 prefectures and 3,329 municipalities (i.e., 662 cities, 1,994 towns, and 583 villages). Each prefecture and municipality has its own autonomous government and elected assemblies.

Because Tokyo is the national capital, the Tokyo metropolitan government has special rights and responsibilities similar to those of a prefecture. By means of Cabinet Orders, cities with populations in excess of 500,000 people can also be designated to perform the functions normally carried out by prefectural governments. Currently there are 12 such "Designated Cities" which have these powers.

The characteristics of prefectures and municipalities within Japan vary significantly. For example, the population of the Tokyo metropolitan area exceeds 10 million people, while the population of Tottoria prefecture is only 600,000 . The village of Aogashima, located within the Tokyo metropolis, has fewer than 200 residents. Geographically, the largest prefecture is Hokkaido, which has a land area that exceeds 800,000 square 
(Legialative Branch)

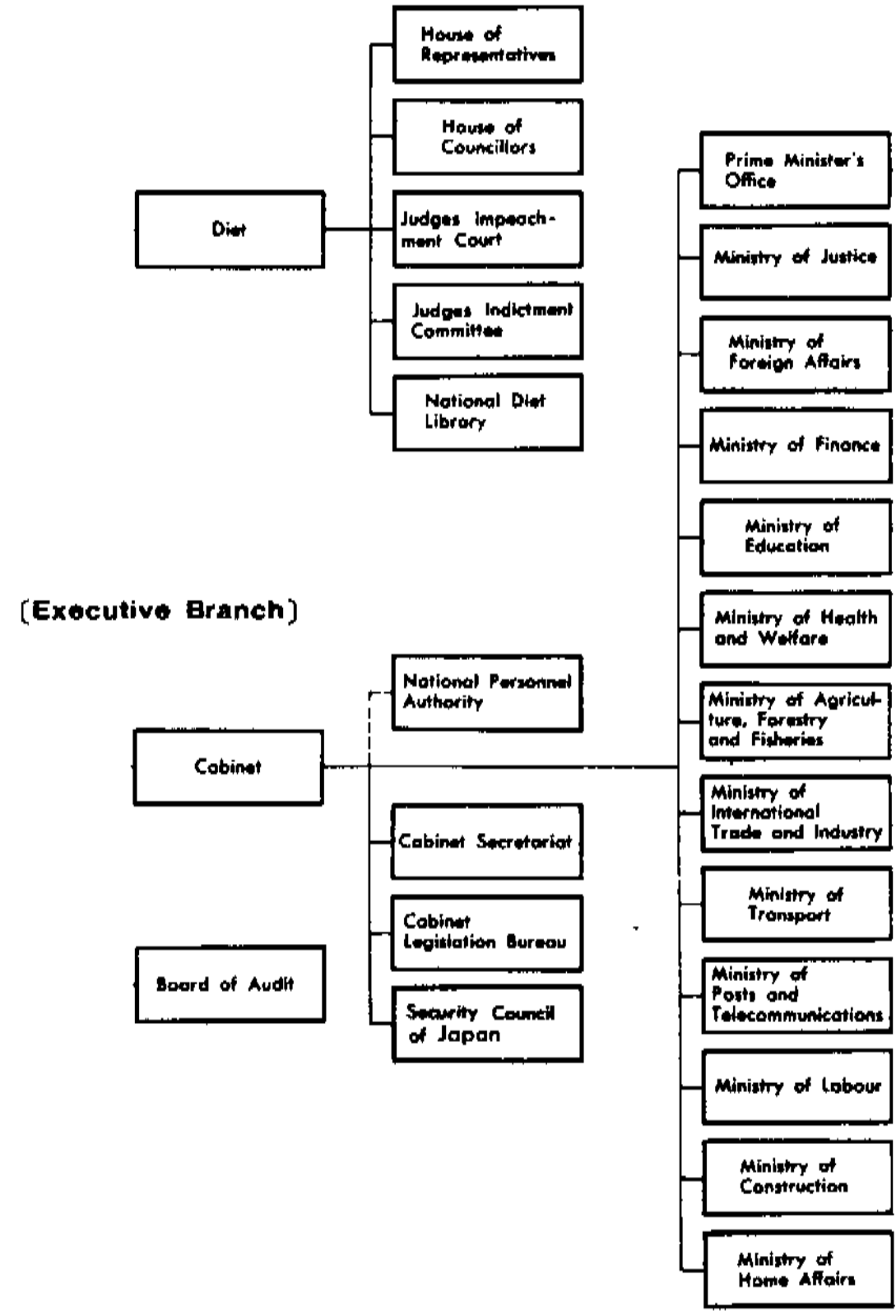

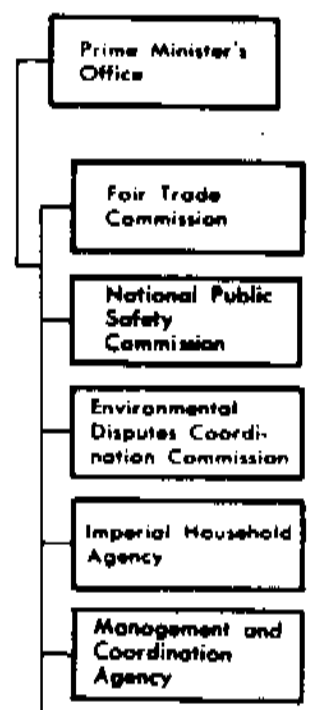
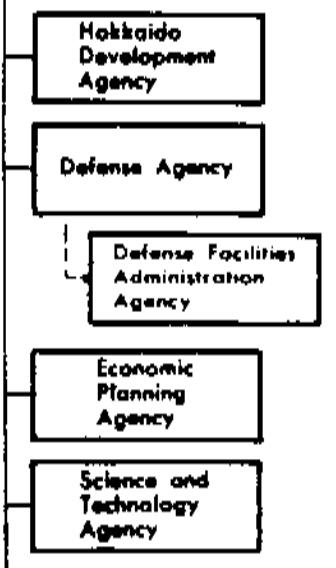

Ervironminat Aoency

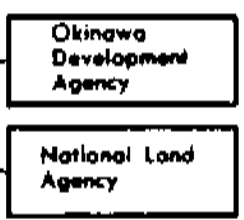

\section{(Judicial Branch)}

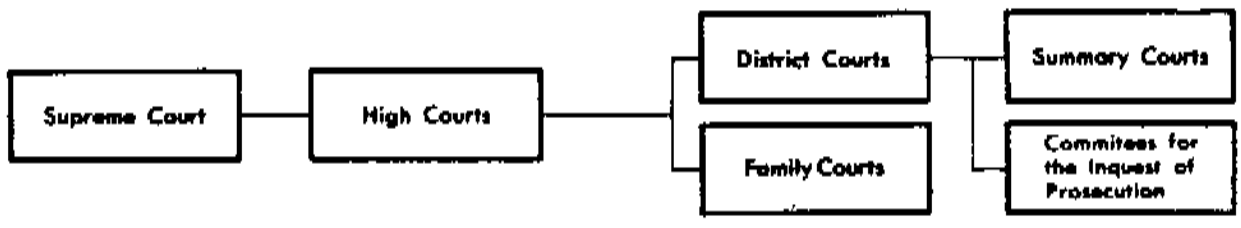


kilometers $(308,000$ square miles); the smallest prefecture is Kagawa, which covers less than 2,000 square kilometers (770 square miles).

Prefectures, the Tokyo metropolitan area, and the municipalities are all referred to as "ordinary local public entities." Additionally, there are "special public entities," which include the 23 special administrative wards of Tokyo. These wards are administratively similar to cities, but some functions normally performed by cities are delegated to metropolitan government.

\subsection{UNDERSTANDING SOLID WASTE MANAGEMENT IN JAPAN}

There is no single approach to integrated solid waste management in Japan, because there is not one approach that is suitable for implementation in all locations. However, Japan is united in its fundamental philosophy regarding the priority of conserving landfill capacity, which drives all the approaches applied. The three case studies of selected Japanese municipalities contained in this report illustrate examples of municipal solid waste management approaches employed in Japan by large, medium, and small municipalities, respectively.

To understand municipal solid waste management in Japan, it is crucial to first recognize the differences among Japanese and American approaches to, and particularly definitions inherent in, municipal solid waste management. Failure to do so can lead to misinterpretation and misuse of the information available on municipal solid waste management in Japan. (For this reason, important differences are highlighted and key terms are defined throughout this document. Appendix B provides a glossary of key terms; it is recommended that the reader peruse this prior to reading the body of the report.) Careful examination of the Japanese methods of recycling (overwhelmingly conducted by the private sector), the materials actually included in their recycling programs, and their methods of accounting, contrasted to those common in the U.S., shows that American assumptions regarding these areas cannot necessarily be applied in determining recycling rates. As our report will show, faulty assumptions, generalizations, and inappropriate methodological applications can and have resulted in the misinterpretation of the effectiveness of recycling in Japan. One example of this is the misuse of "utilization rates" for paper, glass cullet, steel cans, and aluminum cans in Japan as "recycling rates" for post-consumer residential and commercial discards, which has resulted in overestimates of recycling rates in Japan.

\subsection{JAPAN AS "BENCHMARK" FOR U.S. RECYCLING PROGRAM GOALS}

Japan possesses several attributes that make it feasible for the recycling rates it has achieved to serve as a benchmark for establishing achievable recycling goals in the U.S. 
Along with Germany, Japan possesses economic strength and a level of industrialization on par with that of the U.S. Therefore, Japan and the U.S. have comparable economic and technical resources to bring to recycling efforts. Unlike the U.S., Japan, because of its limited indigenous supply of natural resources, imports most of its demand for oil, coal, natural gas, iron ore, bauxite, copper, zinc, tin, cotton, woo7, and lumber. 1 Moreover, unlike the U.S., the Japanese people have a propensity for group action. As discussed by Edwin 0 . Reischauer in his 1977 book, The Japanese, "...the Japanese have been 1iving together for many centuries in much larger and more concentrated masses than have westerners. These conditions may have helped their propensities for group action and their skill in group organization. "2 "Certainly no difference is more significant between Japanese and American, or westerners in general, than the greater Japanese tendency to emphasize the group, somewhat at the expense of the individual. ${ }^{33}$

Given these factors, plus Japan's lack of available Tand area for use as landfills (which together would presumably cause Japan to be extremely conscientious in its recycling efforts), and after adjusting for waste compostion differences between Japan and the U.S. (e.g., Japan has negligable amounts of yard waste), the recycling rates achieved in Japan can provide a legitimate benchmark for both measuring the reasonableness of the 50- to 60-percent recycling goals extant in many U.S. states and communities and establishing expected achievable recycling goals in the U.S.

\subsection{REPORT ORGANIZATION}

The balance of this report is organized as follows. Section 2 discusses the environmental regulatory structure of Japan. Section 3 presents and discusses national waste generation, treatment, and disposal statistics and provides estimated ranges of total discards generation and recycling leve1s. Section 4 presents the three case studies performed and discusses the municipal solid waste management approaches and systems and waste disposition statistics of the municipalities examined. Section 5 contains a summary of the findings of this report. References pertinent to each section are provided at the end of each section. Appendix A delineates the tours and meetings conducted in Japan as well as the names of individuals contacted for information. Appendix $B$ is a glossary of terms used within this report. All numbers in the report are presented in metric units. The approximate U.S. equivalents are provided parenthetically throughout the report, using the metric conversion table

${ }^{1}$ Clean Japan Center, Recycling Guide for Beginners (1992); and Edwin 0 . Reischauer, The Japanese (Cambridge, MA: Belknap Press of Harvard University, 1977), p. 25.

${ }^{2}$ Reischauer, The Japanese, p. 17.

${ }^{3}$ Rejschauer, The Japanese, p. 127. 
provided in Appendix C. Finally, Appendix D provides a listing of selected Japanese and U.S. city population densities for purposes of comparison.

It should be noted that exchange rates between the dollar and yen from 1989 to 1992 have varied from a low of 120 yen per dollar in 7 ate 1992 to a high of 144 yen per dollar in 1989. Therefore, determining a simple dollar equivalent for expenditures made in Japan is not possible. However, for purposes of comparison, a dollar equivalent is provided parenthetically throughout the report for all monetary figures, using an exchange rate of 134.4 yen per dollar, which was the exchange rate at the end of 1990 . 


\section{REFERENCES}

Hershkowitz, Allen and Salerni, Eugene. Garbage Management in Japan: Leading the Way. New York: INFORM Inc., 1987.

Council of Local Authorities for international Relations. Japan Local Government Data Book 1991. Tokyo, 1991. (English)

Levenson, Howard and Wagner, Kathryn D. "Japan Manages Waste - Their Way." Waste Aqe, November 1990.

Reischauer, Edwin 0. The Japanese. Cambridge, MA: The Belknap Press of Harvard University, 1977.

Shapiro, Michae1. Japan - In the Land of the Brokenhearted. New Yark: Henry Holt and Company, 1989.

Statistics Bureau, Management and Coordination Agency. Statistical Handbook of Japan 1992. Tokyo: Japan Statistical Association, 1992. (English)

Thurow, Lester. Head to Head - The Coming Economic Battle Among Japan, Europe, and America. New York: William Morrow and Company, Inc., 1992. 
Environmental protection became an important political issue in Japan during the mid-1960s. The Basic Law for Environmental Pollution Control (the "Basic Law"), which took effect in August 1967, requires that the national government develop environmental quality standards and promulgate regulations to meet these standards in order to protect public health and the natural environment. Local governments were given the responsibility of enforcing these regulations.

The 1970 Diet (which became known as the "Anti-Pol\}ution Diet"), passed new environmental legislation and strengthened existing environmental control laws, including the Basic Law. The Anti-Pollution Diet also strengthened the power of $10 \mathrm{cal}$ governments to promulgate standards and regulations that are more stringent than those of the national government.

The Japanese Environmental Agency (JEA) was established in 1971 for the express purpose of promoting the protection of the environment and coordinating the activities of all other administrative agencies dealing with environmental protection. It comprises four bureaus: the Planning and Coordination Bureau, which includes the Environmental HeaTth Department (about 50 percent of the Bureau's staff); the Natural Conservation Bureau; the Air Quality Bureau, which is responsible for, among other things, air and noise pollution; and the Water Quality Bureau, which is responsible for water pollution and soil contamination.

The JEA is not a "ministry" of the Japanese government, but rather is a special department of the Prime Minister's Office. As such, the JEA cannot submit bills directly to the Diet or propose orders to the cabinet. Neither is it the sole national agency responsible for environmental protection, and it does not have a high budget relative to other agencies. As such, it is a comparatively weak agency within the Japanese bureaucracy. ${ }^{4}$

Japan is divided into 47 prefectures (comparable to states in the U.S.), which contain a combined 3,239 municipalities. The Local Autonomy Act gives prefectures and municipalities the authority to administer and regulate such areas as regional economic development, education, public health, social welfare, and exploitation of natural resources. In general, prefectures address intermunicipal issues, while municipalities focus on intramunicipal issues.

Under the Local Autonomy Law, cities with more than 500,000 inhabitants may be designated by cabinet order to have certain powers and responsibilities normally assumed by prefectures, such as those pertaining

${ }^{4}$ Shigeto Tsuru and Helmet Weidner (eds.), Environmental Policy in Japan (Ed. SigmaBohn, 1989), p. 47. 
to social welfare, health services, and city planning. At present there are 12 such Designated Cities: Sapporo, Sendai, Kawasaki, Yokohama, Nagoya, Kyoto, Osaka, Kobe, Hiroshima, Kitakyushu, Chiba, and Fukuoka. Designated Cities may pass ordinances which create smaller administrative wards that facilitate the implementation of programs that affect the neighborhoods throughout the ward. Tokyo, because it is the center of the national government and the largest city in Japan, has also been give special administrative powers; it has, in turn, created 23 administrative wards. Approximately 24 percent of the 123 million inhabitants of Japan live in either Tokyo or one of the 12 Designated Cities.

Prefectural and municipal governments may enact local ordinances or guidelines to protect public health and the environment, provided that they do not violate the Japanese Constitution or relevant national laws. often Tocal ordinances and guidelines are enacted prior to, or are more restrictive than, similar national laws and guidelines. Pursuant to the Air Pollution Control Act of 1968 and the Water Pollution Control Act of 1970, prefectures and Designated Cities are legally required to monitor air and water quality and are responsible for enforcing national standards. Where monitoring has been established, air quality measurements are usually taken for $\mathrm{SO}_{3}, \mathrm{NO}_{x}, \mathrm{O}_{2}$, and particulate matter, and are sometimes taken for $\mathrm{CO}$ and $\mathrm{AC}$. Water quality monitoring may include measurements of water temperature, $\mathrm{PH}$, conductivity, turbidity, dissolved oxygen, chlorine ions, the biochemical oxygen demand (BOD), and the chemical oxygen demand (COD). The results of the air and water monitoring activities, along with biological, soil, noise, and nature conservation monitoring results, are reported to the Diet each year by the JEA in accordance with Article 7 of the Basic Law. The most recent of these reports is the JEA's "Quality of the Environment in Japan 1992," submitted to the 123rd session of the Diet, May 26, 1992.

In addition to the monitoring of ambient conditions, many local governments require large air polluters to continuously monitor fuel consumption, the sulfur content of the fuel, sulfur dioxide emissions, and nitrogen oxide emissions. These data are telemetered to the local environmental agencies and in some cases are made available to the public. Air emission monitoring is required by the Air Pollution Control Law, but the type and extent of the monitoring is usualiy determined through negotiation of a local "pollution control agreement." On the other hand, water quality effluent monitoring for some substances (e.g., lead) is required by 1 aw.

The environmental monitoring system is used to ensure that the environmental quality standards are being met, allows for rapid response to episodic conditions, and permits the environmental agencies and the public to monitor large pollution sources' compliance with pollution control requirements. The public disclosure of environmental compliance data is considered to be an effective means of enforcing compliance with pollution control requirements.

\footnotetext{
${ }^{5}$ Tsuru and Wejdner (1989), p. 473.
} 
In addition to these monitoring activities, enforcement of environmental regulations is enhanced by laws that make the polluter accountable for health and related damages incurred by the public. Polluters are also subject to fines and imprisonment for pollution-caused health and related damages. 6 Furthermore, in the early 1970s four court cases established legal precedent for monetary-damage suits to be brought against firms that violate environmental laws by those affected by resultant pollution. ${ }^{7}$

Pursuant to Article 21 of the Basic Law, the national government must establish a system to settle environmental disputes. The Environmental Pollution Disputes Settlement Law, passed in 1970, provides a means by which to mediate, reconcile, and arbitrate environmental disputes outside of the courts.

The Japanese environmental movement began to slow down in the mid-1970s as other issues began to take precedence. The JEA's failure, in 1976, to pass an Environmental Impact Bill exemplifies this change in priorities. The bill was opposed by the Ministry of International Trade and Industry (MITI), the Ministry of Transportation, and the Ministry of Construction. These ministries are responsible for supporting businesses and/or promoting economic growth. After repeated failures to reach agreement on a compromise bill, the JEA, in 1984, chose to issue guidelines for the preparation of environmental impact assessments rather than to continue to pursue a legal mandate for their preparation.

The practice of preparing an environmental impact assessment for a proposed large-scale facility or project can be traced back to the proposed siting, in 1964, of a coal-fired power plant in the Isogo ward in Yokohama. In response to the opposition to the siting of the new power plant, the Mayor of Yokahama, who was originally opposed to the project, commissioned a team of experts to evaluate the project's potential environmental impacts. Based upon this environmental assessment, a set of pollution control measures that exceeded the then current environmental laws were incorporated into a pollution control agreement between the facility operator and the city. This agreement paved the way for the construction of the facility.

The practice of conducting an environmental impact assessment and executing a local pollution control agreement is now common and often results in the application of "best available control technologies" for new facilities. These agreements, however, do not have the weight of 1 aw because they are voluntary. Yet, as a rule, these agreements are

\footnotetext{
${ }^{6}$ Tsuru and Weidner (1989), p. 39.

${ }^{7}$ Tsuru and Weidner (1989), p. 34.

${ }^{8}$ Michio Hashimoto, Economic Development and the Environment: The
} Japanese Experience (Ministry of Foreign Affairs, April 1992), p. 11 . 
honored. ${ }^{9}$ Although some communities have passed local laws that require the preparation of environmental impact statements (e.g., Tokyo, Hokkaido, and Kawasakj), environmental impact assessments for large-scale projects are generally conducted by custom rather than through 1 aw.

\subsection{ENVIRONMENTAL LAWS AFFECTING SOLID WASTE MANAGEMENT}

The Basic Law provides the framework for pollution controt, including solid waste management. Within this framework, a number of other 1 aws were enacted to protect the environment. The principal law affecting solid waste disposal is the Waste Disposal and Public Cleansing Law (the "Waste Disposal Law"), which was enacted by the Anti-Pollution Diet in 1970 and became effective in September 1971. The Waste Disposal Law was amended in 1974, 1976, 1983, and 1991. The Law for Promotion of Utilization of Recyclable Resources (the "Recycling Law") became effective in October 1991.

Pollution prevention laws affecting solid waste management include the Air Pollution Control Law, the Water Pollution Control Law, the Noise Control Law, the Vibration Control Law, and the offensive Odor Control Law. Additionally, a number of 1 aws related to enforcement and the payments of fines and/or damages have been passed, such as the Laws for the Compensation of Health Damages Caused by Environmental Pollution, Settlement of Pollutant-Related Disputes, and Punishment for PollutionRelated Disputes. Ocean dumping of waste and combustion of waste on ships or marine facilities are regulated by the Law for the Prevention of Marine Pollution and Maritime Disaster, while the use of sea-area land as disposal and processing sites is regulated under the Law for the Arrangement of Regional Coastal Environment Centers.

Key provisions of the Air Pollution Control, Water Pollution Control, Recycling, and Waste Disposal Laws that affect solid waste management are described below.

\subsubsection{Air and Water Pollution Control Laws}

The Air Pollution Control Law regulates emissions of sulfur oxides, particulate matter, hydrogen chloride, and nitrogen oxides emitted from municipal solid waste (MSW) combustion facilities. The national emission limits are provided in Table $2-1$.

The Japanese government has not promulgated any regulations governing the control of dioxins and furans from the combustion of MSW or the disposal of the resultant ash. Rather, after the completion of a five-year study (1985 through 1990) of the mechanism of formation and degradation of dioxins, the Ministry of Health and Welfare issued a set of guidelines for MSW combustion and ash disposal.

\footnotetext{
${ }^{9}$ Tsuru and Weidner (1989), p. 64.
} 
TABLE 2-1

JAPANESE NATIONAL EMISSION STANDARDS

ITEM

PARTICULATE MATTER

\section{Continuous Incinerators}

Emission

Standards

Remarks

Emission

Standards

Remarks
Less than $0.15 \mathrm{~g} / \mathrm{Nm}^{3}$

Applied for units with

flue gas exhaust greater

than or equal to $40,000 \mathrm{Nm}^{3} / \mathrm{h}$

Special emission standards

Less than $0.08 \mathrm{~g} / \mathrm{Nm}^{3}$

\section{SULFUR OXIDES}

Less than $\mathrm{q}\left(\mathrm{Nm}^{3} / \mathrm{h}\right)$ when

calculated based on:

$\mathrm{q}=\mathrm{K} \times 10^{-3} \times \mathrm{He}^{2}$

He: Effective height of

a stack

K: A value set by area
Less than $0.5 \mathrm{~g} / \mathrm{Nm}^{3}$

Applied for units with

flue gas exhaust less than

$40,000 \mathrm{Nm}^{3} / \mathrm{h}$

Special emission standards

Less than $0.15 \mathrm{~g} / \mathrm{Nm}^{3}$

HYDROGEN CHLORIDE

Less than $700 \mathrm{mg} / \mathrm{N}^{3}$

Calculated in terms of $0_{2}=12 \%$

Less than 430ppm in terms of concentration others

Less than $0.5 \mathrm{~g} / \mathrm{Nm}^{3}$

Special emission standards

Less than $0.25 \mathrm{~g} / \mathrm{Nm}^{3}$

NITROGEN OXIDES

\section{0ppm}

Calculated in terms of $\mathrm{O}_{2}=12 \%$

Flue gas

More than $40,000 \mathrm{Nm}^{3} / \mathrm{h}$

Source: Plastic Waste Management Institute, Surveys and Public Relations Department, Plastic Waste: Disposal and Recycling, Past, Present and Future in Japan (Tokyo: 1991). 
The guidelines differ according to the various types of combustion technology employed in Japan (i.e., continuous combustion, semi-continuous combustion, mechanical-batch combustion, and fixed-grate batch combustion), and according to whether a facility is new or existing. The guidelines are strictest for new, continuous combustion facilities, which represent more than 70 percent of the combustion capacity in Japan. Generally, the combustion guidelines focus on achieving complete combustion, lower temperatures of the flue gas entering the particulate control device, and improved collection efficiency of the pollution control equipment. The guidelines for newly constructed continuous combustion facilities are provided in Table 2-2. The numerical values of these Japanese standards cannot be directly compared to U.S. standards absent thorough analysis of the measuring techniques, averaging times, etc., that have been employed.

The guidelines for ash disposal take into account the low solubility of dioxins and furans in water and their high adsorptivity to soils and suggest that leachate treatment to prevent solids discharges and the use of daily cover at the landfill are adequate to control the slight traces of dioxins and furans in the ash residue.

The Japanese have not promulgated any regulations for the control of heavy metal emissions. Many local communities attempt to reduce mercury enissions by separating, at the source, materials that contain mercury, such as thermometers, dry cell batteries, and fluorescent light bulbs.

The Water Pollution Control Law regulates effluent discharges from combustion and processing facilities. Leachate from landfills is regulated by the Waste Disposal Law. The standard, however, is the same as those in the water Pollution Control Law. The national effluent standards affecting MSW facilities are provided in Table 2-3.

\subsubsection{Recycling Law}

The Ministry for International Trade and Industry (MITI), the sponsoring Ministry for the Recycling Law, commissioned a subcommittee of the Industrial Structural Problems Council to make suggestions for promoting recycling in Japan. The Counci1's report, entitled "Desirable Directions of Waste Disposal and Recycling," was submitted to the Diet in December 1990. The Recycling Law, which included many of the suggestions made in this report, was passed in April 1991 and became effective in October 1991.

The Recycling Law establishes policies and guidelines for the recycling of secondary materials. Recycling is broadly defined to include both the recovery and the reuse of post-consumer materials and industrial byproducts.

Article 23 of the Recycling Law specifies that the Ministers of International Trade and Industry, Construction, Agriculture, Forestry and Fisheries, Finance, Health and Welfare, and Transport, and the Director of 
TABLE 2-2

JAPANESE NATIONAL GUIDELINES FOR CONTROL OF DIOXINS AND FURANS FROM NEW, CONTINUOUSLY-OPERATED MSW COMBUSTION FACILITIES

\begin{tabular}{|c|c|c|}
\hline Maximum Co Concentration & $\bullet$ & $\begin{array}{l}50 \mathrm{ppm} \\
4 \text {-hour average concentration } \\
\text { converted at } \mathrm{O}_{2}=12 \%\end{array}$ \\
\hline Minimum Temperature & $\bullet$ & $800^{\circ} \mathrm{C}$ \\
\hline Minimum Retention Time & $\bullet$ & $\begin{array}{l}2 \text { sec. for full-boiler type } \\
\text { (for gas cooling) and } 1 \text { sec. } \\
\text { for other types }\end{array}$ \\
\hline Minimum $\mathrm{O}_{2}$ Concentration & - & $6 \%$ \\
\hline Maximum Particulates Concentration & $\bullet$ & $20 \mathrm{mg} / \mathrm{Nm}^{3}$ \\
\hline Maximum Gas Temperature & $\bullet$ & $\begin{array}{l}200^{\circ} \mathrm{C} \\
\text { At the inlet of dust } \\
\text { collector. It could be } 230^{\circ} \mathrm{C} \\
\text { if co is less than } 30 \mathrm{ppm} \text { when } \\
\text { using catalyst for nitrogen } \\
\text { oxides reduction. }\end{array}$ \\
\hline
\end{tabular}

Source: Ministry of Health and Welfare, "Summary of Study on PCDDs and PCDFs Formulation During Municipal Waste Treatment." 
TABLE 2-3

JAPANESE NATIONAL UNIFORM EFFLUENT STANDARDS

\begin{tabular}{|c|c|c|}
\hline & WATER QUALITY ITEMS & $\begin{array}{l}\text { UNIFORM EFFLUENT STANDARD } \\
\text { (ORDER OF THE PRIME } \\
\text { MINISTER'S OFFICE) }\end{array}$ \\
\hline Hazardous I tems & $\begin{array}{l}\text { Cadmium Compounds } \\
\text { Cyanide Compounds } \\
\text { Organic Phosphorous Compounds } \\
\text { Lead Compounds } \\
\text { Hexavalent Chromium Compounds } \\
\text { Arsenic Compounds } \\
\text { Mercury Compounds } \\
\text { Alkyl Mercury Compounds } \\
\text { PCB }\end{array}$ & $\begin{array}{l}0.1 \mathrm{mg} / \mathrm{l} \\
1.0 \mathrm{mg} / \mathrm{l} \\
1.0 \mathrm{mg} / \mathrm{l} \\
1.0 \mathrm{mg} / \mathrm{l} \\
0.5 \mathrm{mg} / \mathrm{l} \\
0.5 \mathrm{mg} / \mathrm{l} \\
0.05 \mathrm{mg} / \mathrm{l} \\
\text { Not detectable } \\
0.003 \mathrm{mg} / \mathrm{l}\end{array}$ \\
\hline $\begin{array}{l}\text { It tems of Living } \\
\text { Environment }\end{array}$ & $\begin{array}{l}\text { Concentration of Hydrogen Ion (pH) } \\
\text { BOD } \\
\text { COD } \\
\text { SS } \\
\text { Normal Hexane Extracting Substances } \\
\quad \text { (minerals) } \\
\text { Normal Hexane Extracting Substances } \\
\quad \text { (animal/plant) } \\
\text { Phenols } \\
\text { Copper } \\
\text { Zinc } \\
\text { Soluble Iron } \\
\text { Soluble Manganese } \\
\text { Chromium } \\
\text { Fluorine } \\
\text { Number of Colon Bacillus Groups }\end{array}$ & $\begin{array}{l}5.8 \sim 8.6 \text { ( } 5.0 \sim 9.0 \text { for the sea) } \\
160 \mathrm{mg} / \mathrm{l} \text { (an average } 120 \\
\mathrm{mg} / \mathrm{l} \text { dayt ime) } \\
160 \mathrm{mg} / \mathrm{l} \text { (an average } 120 \\
\mathrm{mg} / \mathrm{l} \text { dayt ime) } \\
200 \mathrm{mg} / \mathrm{l} \text { (an average } 150 \\
\mathrm{mg} / \mathrm{l} \text { dayt ime) } \\
5 \mathrm{mg} / \mathrm{l} \\
30 \mathrm{mg} / \mathrm{l} \\
5 \mathrm{mg} / \mathrm{l} \\
3 \mathrm{mg} / \mathrm{l} \\
5 \mathrm{mg} / \mathrm{l} \\
10 \mathrm{mg} / \mathrm{l} \\
10 \mathrm{mg} / \mathrm{l} \\
2 \mathrm{mg} / \mathrm{l} \\
15 \mathrm{mg} / \mathrm{l} \\
\text { an average } 3,000 \text { dayt ime }\end{array}$ \\
\hline
\end{tabular}

Remarks: Items of living environment are applied only to facilities discharging more than $50 \mathrm{~m}^{3} /$ day. Items of $1 \mathrm{iving}$ environment are applied only, to landfills with an area greater than or equal to $1,000 \mathrm{~m}^{2}$.

Source: Plastic Waste Management Institute, Surveys and Public Relations Department, PJastic Waste: Disposal and Recycling, Past, Present and Future in Japan (Tokyo: 1991). 
the JEA (collectively referred to as the "Competent Ministers") are required to develop and publish policies to promote the use of recyclable materials, and if necessary, provide criteria and standards for the labeling of specifically designated products.

The Recycling Law outlines the general responsibilities of governments, businesses, and consumers in promoting the use of recycled materials. The national, prefectural, and municipal governments are responsible for helping to secure funding, promoting research and development, and developing public awareness campaigns. Businesses are encouraged to increase their use of secondary materials and to promote post-consumer and by-product recycling. Consumers are to cooperate with the actions taken by government and businesses to promote recycling.

Because each waste material has distinct attributes and each industry has distinct problems to solve, the Industrial Structural Problems Council report recommended the development of a comprehensive waste management and recycling policy tailored to individual commodities and industries. Based on that report, the MITI prepared guidelines to promote waste reduction and recycling, as provided in Table 2-4. ${ }^{10}$ The guidelines are generally implemented over five years; progress is reviewed annually; and, if necessary, the policies are modified. To further emphasize the Japanese approach to developing recycling programs that are material-and/or industry-specific, the Recycling Law defines "Specifically-Designated Industries"; "First-Class-Designated Products"; "Second-Class-Designated Products"; and "Designated By-Products," each of which is designated by Cabinet Order.

The current Specifically-Designated Industries, as designated by Cabinet Order, are paper manufacturing (to promote waste paper utilization as a raw material), glass container manufacturing (to promote cullet utilization), and the construction industry (to promote earth and sand, asphalt, and concrete block utilization as raw materials). The competent Ministers are responsible for developing criteria for the promotion and utilization of recyclable resources and for providing guidance and advice to each Specifically-Designated Industry. Each of these industries must prepare plans to promote the utilization of recyclable resources, increase recyclable resources utilization rates, develop and improve technologies required to utilize recyclable resources, and construct the necessary facilities to utilize recyclable resources.

The current First-Class-Designated Products, as designated by Cabinet order, are automobiles and home electrical appliances such as unit air conditioners, televisions, refrigerators, and washing machines. The

${ }^{10}$ Plastic Waste Management Institute, Surveys and Public Relations Department, Plastic Wastes: Disposal and Recycling, Past, Present and Future in Japan (1991), p, 176.

${ }^{11}$ Nobaru Yumoto, "The Law For Promotion of Utilization of Recyclable Resources $^{\prime \prime}$ (Octaber 1992), pp. 4-8. 
TABLE 2-4

MITI RECYCLING GUIDELINES FOR GENERAL WASTE AND AUTOMOBILES

1. GUIDELINES ON MUNICIPAL WASTES, ETC.

WASTE PRESENT SITUATIONS AND PROBLEMS CONTENTS OF GUIDELINES, ETC.
Paper Generated in large quantities (holding considerable share in both waste weight and volume).
- Some types of waste paper are proliferating.
1. Promotion of waste paper recycling:
(1) Target: "Recycling 55 Plan" to achieve the utilization rate of $55 \%$ by FY 94 (from $48 \%$ in 1988).
(2) Expanding use of waste paper in papermaking.
(3) Greater use of recycled paper.

2. Promotion of waste paper collection:
(1) To promote collection of used office paper
which has recently been growing relatively fast.
(2) To promote collection of waste paper from general households too.

3. Paper packs: To offer education programs to promote collection, while encouraging the manufacture of products which permit easier recycting.

\section{Steel Cans - Generated in large quantities. - Easy to litter.}

1. Promotion of recycling:

(1) Target - to raise the utilization rate to $60 \%$ by 1995 (from $44 \%$ in 1989).

(2) Recycling Measures - to offer support/ cooperation to help municipal governments promote waste separation in order to ensure efficient recycling through mass collection/ recycling.

2. Anti-1itter measures:
(1) To conduct model tests in areas notorious for littering cans, like tourist resorts.
(2) To encourage introduction/practice of a commendating system. 
TABLE 2-4 (CONTINUED)

MITI RECYCLING GUIDELINES FOR GENERAL WASTE AND AUTOMOBILES

1. GUIDELINES ON MUNICIPAL WASTES, ETC.

WASTE PRESENT SITUATIONS AND PROBLEMS

(Steel Cans, (cont'd.)
CONTENTS OF GUIDELINES, ETC.

(3) To encourage organization of seminars and $P R /$ education programs.

3. To encourage the use of cans featuring non-detachable tabs (incl. stay-on-type ones).
Aluminum

Cans
- Generated in large quantities.

- Hard to practice waste separation.

- Easy to Titter.
1. Promoting of Recycling:

(1) Target - to raise the utilization rate to $60 \%$

by late fiscal 1994 (from $43 \%$ in fiscal 1989).

(2) Recycling Measures:

1 Establishment/upgrading of collection routes 2 Thorough labeling efforts

3 Positive PR/educational programs

4 Promotion of R\&D efforts

2. Anti-litter measures:

(1) To conduct model tests in areas notorious for

littering cans, like tourist resorts.

(2) To encourage introduction/practice of a commendating system.

(3) To encourage organization of seminars and PR/ educational programs.

3. To encourage the use of cans featuring non-detachable tabs (incl. stay-on-type ones).
1 
TABLE 2-4 (CONTINUED)

MITI RECYCLING GUIDELINES FOR GENERAL WASTE AND AUTOMOBILES

I. GUIDELINES ON MUNICIPAL WASTES, ETC.

WASTE PRESENT SITUATIONS AND PROBLEMS CONTENTS OF GUIDELINES, ETC.

Glass - Generated in large quantities.

Bottles - Some glass bottles are easy to litter.

1. Promotion of cullet reuse/recycling:

(1) Greater use of cullets:

1 Target - to raise the share of cullets used in glass-bottle manufacturing to $55 \%$ by fiscal 1995 (from 49\% in 1988).

(2) Greater use of returnable bottles.

2. Promotion of bottle collection efforts.

White Goods - Harder disposal resulting from larger capacity.

- Sharply increasing collection fees.
1. Advance measures to make waste reduction/recycling/ disposal easier.

2. Establishment of a marketing-route-based collection system.

3. Education to encourage longer use.
Plastics

- Inefficient collection due to the disproportionate bulkiness to their weight.

- Their high heat value in general can lower incinerating capacity or damage incinerators, when oldfashioned ones are in use.

- When landfilled, land can remain unstable for years.
1. Promotion of recycling - In regard to waste plastics usable as raw materials, following measures must be taken in an effort to promote their recycling.

(1) Beverage PET bottles:

1 To conduct model recycling projects.

2 To promote the use of identification labeling.

3 To help support the establishment of recycling businesses and encourage the greater use of recycled resins.

4 To promote the establishment/greater employment of recommended standards. 
TABLE 2-4 (CONTINUED)

MITI RECYCLING GUIDELINES FOR GENERAL WASTE AND AUTOMOBILES

1. GUIDELINES ON MUNICIPAL WASTES, ETC.

\section{Plastics}

(cont'd.)
(2) Expanded PS fish boxed/white-goods packaging materials:

1 To encourage installation of melt-andmold recycling machines at major markets (fish boxes).

2 To expand/upgrade collection systems (whitegoods packaging materials).

3 To develop efficient melt-and-mold recycling machines.

(3) Agricultural PVC films:

1 To raise the target utilization rate to $50 \%$ from present $38 \%$.

2 To find additional uses of recycled resins.

(4) Expanded PS distribution trays:

1 To conduct collection/recycling model tests.

2 To develop efficient melt-and-mold recycling machines.

2. Promotion of energy recovery/use: in regard to waste plastics hardly recycled as raw materials, adequate incineration efforts paired with energy recovery/use must be made.

(1) To study how to cooperate systematically with municipal governments committing to energy recovery in the form of refuse-derived fuels including plastics.

(2) Technological development to improve efficiency of energy recovery, etc. 
TABLE 2-4 (CONTINUED)

MITI RECYCLING GUIDELINES FOR GENERAL WASTE AND AUTOMOBILES

1. GUIDELINES ON MUNICIPAL WASTES, ETC.

\section{WASTE PRESENT SITUATIONS AND PROBLEMS}

Plastics

(cont'd.)
CONTENTS OF GUIDELINES, ETC.

3. Plastic waste reduction:

(1) To encourage the manufacture of thinner products with longer service life and the like in an effort to discourage the growth of plastic wastes.

(2) To encourage adequate packaging through development of new packaging materials, etc.

4. Others:

(1) FPR bathtubs - To construct a systematic disposal system to cover bulky FRP bathtubs hard to be disposed of by municipal governments.

(2) Development/use of biodegradable plastics to develop/use "biodegradable plastics" which are decomposed by bacteria, etc., present in the environment (i.e., soils), thus capable of alleviating loads on natural environment.

(3) To help the Plastic Waste Management Institute update its activities.
Automobiles
1. Fundamental reviews on materials, manufacturing processes, etc.

2. Tougher measures to deal with abandoned automobiles.

3. Cooperation in collecting efforts through marketing routes, etc.

4. Positive $P R /$ educational programs to prevent auto abandonment. 
TABLE 2-4 (CONTINUED)

MITI RECYCLING GUIDELINES FOR GENERAL WASTE AND AUTOMOBILES

1. GUIDELINES ON MUNICIPAL WASTES, ETC.

WASTE PRESENT SITUATIONS AND PROBLEMS CONTENTS OF GUIDELINES, ETC.

Bicycles - Abandoned bicycles at station fronts, etc.
1. Industry's cooperation in disposal efforts by municipal governments.

2. Campaigns to eliminate abandoned bicycles.

3. Development/studies on model bicycles which permit waste reduction and easier disposal.

4. Educational programs to encourage longer use.

1. Preparation of mercury reducation $p l a n s$.

2. Positive measures taken to promote collection of mercury cells, which include installation of collection boxes at shops and aggressive ads calling for recycling.

\begin{abstract}
Casset
Cyl inders

\& Aerosols

(incl. paint

sprays)

Basic

Concept on

Packaging

- Excessive and wasteful packaging is frequently noted.

flammable gases of fuels can cause troubles during collection/disposal.
\end{abstract}

- Containing mercury.
1. Labeling strictly requiring confirmation that an aerosol container is completely empty when discarded.

2. Promotion of safe disposal.

1. To encourage adequate packaging practice among product among product makers and distributors (void volume ratio, ratio of packaging cost, self-restraint on excessive use of trays, etc.) 
TABLE 2-4 (CONTINUED)

MITI RECYCLING GUIDELINES FOR GENERAL WASTE AND AUTOMOBILES

1. GUIDELINES ON MUNICIPAL WASTES, ETC.

WASTE PRESENT SITUATIONS AND PROBLEMS

Basic
Concept on
Packaging
(cont'd.)

(cont'd.)

CONTENTS OF GUIDELINES, ETC.

2. To encourage adequate packaging among packaging material makers and distributors.

3. To promote introduction of a system to enable customers to select packaging at the distribution stage.

1. Advance measures to make waste reduction/recycling/ disposal easier.

2. Establishment of a marketing-route-based collection system.

3. Promotion of wooden/metallic furniture recycling.

4. Studies on labeling to make recycling/disposal easier.

5. Formation of consulting services on disposal/recycling.

6. Positive PR/education programs.

Spring

Mattresses
- Bulky and frequently hard to be even crushed.
I. Advance measures to make waste reduction/recycling/ disposal easier.

2. Development of disposal technologies, etc.

3. Establishment of collection routes.

4. Positive PR/education programs. 


\section{TABLE 2-4 (CONTINUED)}

MITI RECYCLING GUIDELINES FOR GENERAL WASTE AND AUTOMOBILES

1. GUIDELINES ON MUNICIPAL WASTES, ETC.

\begin{tabular}{|c|c|c|}
\hline WASTE & PRESENT SITUATIONS AND PROBLEMS & CONTENTS OF GUIDELINES, ETC. \\
\hline Carpets & $\begin{array}{l}\text { - Hard to be crushed. } \\
\text { - Hard to be incinerated. }\end{array}$ & $\begin{array}{l}\text { 1. Establishment of collection routes. } \\
\text { 2. Technological R\&D planning. } \\
\text { 3. Positive PR/educational programs. }\end{array}$ \\
\hline $\begin{array}{l}\text { Futon } \\
\text { (Japanese } \\
\text { bedquilts) }\end{array}$ & - Hard to be crushed. & $\begin{array}{l}\text { 1. Establishment of collection routes. } \\
\text { 2. Studies on recycling feasibility. } \\
\text { 3. Positive PR/educational programs. }\end{array}$ \\
\hline
\end{tabular}

Source: Plastic Waste Management Institute, Surveys and Public Relations Department, Plastic Waste: Disposal and Recycling, Past, Present and Future in Japan (Tokyo: 1991). 
Competent Ministers are responsible for developing criteria to promote post-consumer recycling of these products and for providing guidance and advice, as necessary, to the manufacturing and distribution industries for these products. The manufacturing and distribution industries must consider in the design, manufacturing, and repair of these products the use of recyclable materials, the potential post-consumer reuse or recycling of the materials used in these products, and the safe processing and disposal of the products' non-recyclable components. Such considerations include methods to enhance waste reduction, recycling, and disposal, such as designing easily detachable component parts, labeling the material contents of component parts, reducing the toxicity of component parts, and increasing the durability of products and parts.

Current Second-Class-Designated Products, as determined by Cabinet Order, are steel and aluminum beverage cans, including cans used for alcoholic beverages. To facilitate the separation and recycling of Second-ClassDesignated Products, their manufacturers must label each container to identify its material contents. The Competent Ministers are responsible for developing labeling standards.

The Designated By-Products, as determined by Cabinet Order, are currently slag from iron blast furnaces and steel manufacturing and rolling industries; coal ash from electric utilities; and earth and sand, concrete blocks, asphalt, and timber from the construction industry. The competent Ministers are responsible for establishing criteria for the promotion and utilization of Designated By-Products and for giving advice, guidance, and, if necessary, directives for carrying out their mandates. The affected industries are responsible for preparing plans that include approaches for increasing the utilization of these Designated By-Products, processing and recovering them, improving the technologies use to process them, and constructing the facilities necessary to implement the program.

Unijke in the U.S., recycling goals that have been established in Japan are material-specific and include the recycling of manufacturing byproducts as well as post-consumer products. In particular, the Recycling Law estabijishes the following utilization goals: a waste paper utilization rate of 55 percent by fiscal year 1994 (from 48 percent in 1988); a stee? can utilization rate of 60 percent by fiscal year 1995 (from 44 percent in 1989); an aluminum can utilization rate of 60 percent by fiscal year 1994 (from 43 percent in 1989); and a glass cullet utilization rate of 55 percent by fiscal year 1995 (from 49 percent in 1988).

\subsubsection{Waste Disposal and Public Cleansing Law}

Solid waste management in Japan, including collection, recycling, processing, and disposal, is implemented in accordance with the Waste Disposal and Pubic Cleansing Law (the "Waste Disposal Law"). The Ministry of Health and Welfare (MHW) is responsible for administering the Waste Disposal Law. Waste is defined in Article 2 of the Waste Disposal Law, 1970, as amended, as "refuse, big refuse, ashes, sludge, human excretion, 
waste oil, waste acid and alkali, carcasses and other filthy and unnecessary matters, which are in solid or liquid state (exciuding radioactive wastes or [that which] is polluted by radioactive waste)." other wastes not subject to the Waste Disposal Law are dredge spoils, aquatic and plant residues from fishing activities, earth, sand, and other similar materials used for land reclamation.

Waste is categorized as either Industrial Waste or General Waste. Industrial waste is that generated by business and industrial activities and either specifically defined within the Waste Disposal Law or determined by Cabinet order. Industrial Waste is currently divided into 19 groups, as delineated in Table 2-5. General Waste includes a11 wastes not defined as Industrial Waste and is essentially residential waste and wastes that are similar to residential waste but generated by businesses, institutions, and industry. The 1991 amendment to the Waste Disposal Law created a subcategory, Specially Managed Wastes, for both Industrial and General Waste. Specially Managed Wastes are those that require special treatment or disposal because they are hazardous, explosive, toxic, infectious, or in other ways possibly detrimental to human health or the environment. Figure $2-1$ is a schematic of the waste classifications defined in the Waste Disposal Law.

The disposal of Industrial Waste is the responsibility of the generator. Business and industrial enterprises must endeavor to reuse or in other ways reduce the amount of waste requiring disposal. Moreover, consideration must also be given to ease of treatment and disposal of the products or packaging manufactured, processed, or sold by such businesses and industries.

Municipalities (i.e., cities, towns, and villages) are responsible for planning, developing, and implementing waste management systems, including collection, transport, recycling, processing, and disposal of the General Waste generated within their respective communities. Municipalities are entitled to dispose of Industrial Waste that they deem can be disposed of with General Waste. Municipalities also have the right to establish, through municipal ordinances, charges for collecting, transporting, processing, and disposing of General and Industrial Wastes (Waste Disposal Law, 1970, as amended, Articles 6 and 13).

The Waste Disposal Law also gives municipalities the exclusive right to manage General Waste by explicitly prohibiting private enterprises from establishing businesses for the collection, transport, processing, and disposal of General Waste without the permission of the mayor of the municipality. Excluded from this prohibition are businesses that collect, transport, and dispose of their own waste; businesses established to collect waste for the purpose of reuse and recycling; and other specific cases determined by ordinance of the MHW. Prices for such private services cannot exceed those charged by the municipality in accordance with Municipal Ordinance. Municipalities must also notify the governor of the prefecture of any plans to construct or significantly modify a General Waste processing or disposal facility. Such facilities must satisfy the performance standards, and their operators must meet the specified qualification requirements, established by the MHW. 
TABLE 2-5

THE 19 GROUPS OF INDUSTRIAL WASTES SPECIFIED IN THE WASTE DISPOSAL. LAW OR ASSOCIATED GOVERNMENT ORDINANCES

Legislation 1. Cinders

2. Sludge

3. Waste 0 il

4. Waste Acid

5. Waste A1kali

6. Waste Plastics
Coal cinders, residual ash from industrial incinerators, wastes generated when a furnace is cleaned, other incineration residues.

Muddy wastes resulting from wastewater treatment at plants, muddy wastes generated from manufacturing processes of various manufacturing industries, surplus sludge from the activated sludge process, sludge in wastewater from pulp mills, etc.

Mineral oil, animal/vegetable oil, lubricants, tar pitch, etc.

All kinds of waste acid liquids, including waste sulfuric acid and various kinds of waste organic acid.

All kinds of waste alkali liquids, such as waste soda liquid.

All kinds of synthetic polymer compounds in a solid and/or liquid state, including waste synthetic resins and waste synthetic rubber.
Government 7. Waste Paper Ordinance
Waste paper and waste cardboard from pulping, paper-making, paper-processing, newspaper, publishing, bookbinding, and printed-material processing industries, waste paper coated with PCB.

8. Waste Wood

9. Waste Fibers
Wood chips, sawdust, bark and others from other timber/wooden product manufacturing industries (including furniture makers), pulp mills, and wholesalers of imported timber.

Waste natural fibers generated from any textile industries other than the textile product manufacturing industry. 
TABLE 2-5 (CONTINUED)

THE 19 GROUPS OF INDUSTRIAL WASTES SPECIFIED IN THE WASTE DISPOSAL LAW OR ASSOCIATED GOVERNMENT ORDINANCES

(Government Ordinance, cont'd.)
10. Animal/Plant Residues

11. Waste Rubber

12. Metal Scraps

13. Glass/Waste Ceramics

14. S1ags

15. Demolished Building Materials

16. Livestock Excrement

17. Livestock Corpses

18. Particulate Matter
Wheat-gluten dregs, brewing lees, fermentation dregs, bony parts of fish and animal, etc.

Waste natura1 rubber.

Polishing and cutting chips of steel and nonferrous metals, etc.

Waste glass, waste refractories, waste ceramics, etc.

Slags from blast, open-hearth, and electric furnaces, mining wastes, etc.

Broken pieces of concrete, bricks, and the like resulting from demolition of structures

Excretions of cattle, pigs, garden fowl, and others generated from the livestock industry.

Corpses of cattle, pigs, garden fow 1 , and other generated from the livestock industry.

Particulate matter collected by dust collectors installed at smoke-generating facilities and sludge/waste-oil incineration facilities.

19. Residues generated from industrial wastes specified in the above groups 1 through 18 .

Source: Plastic Waste Management Institute, Surveys and Public Relations Department, Plastic Waste: Disposal and Recycling, Past, Present and Future in Japan (Tokyo: 1991). 


\section{FIGURE 2.1: SCHEMATIC OF JAPANESE WASTE CLASSIFICATIONS}

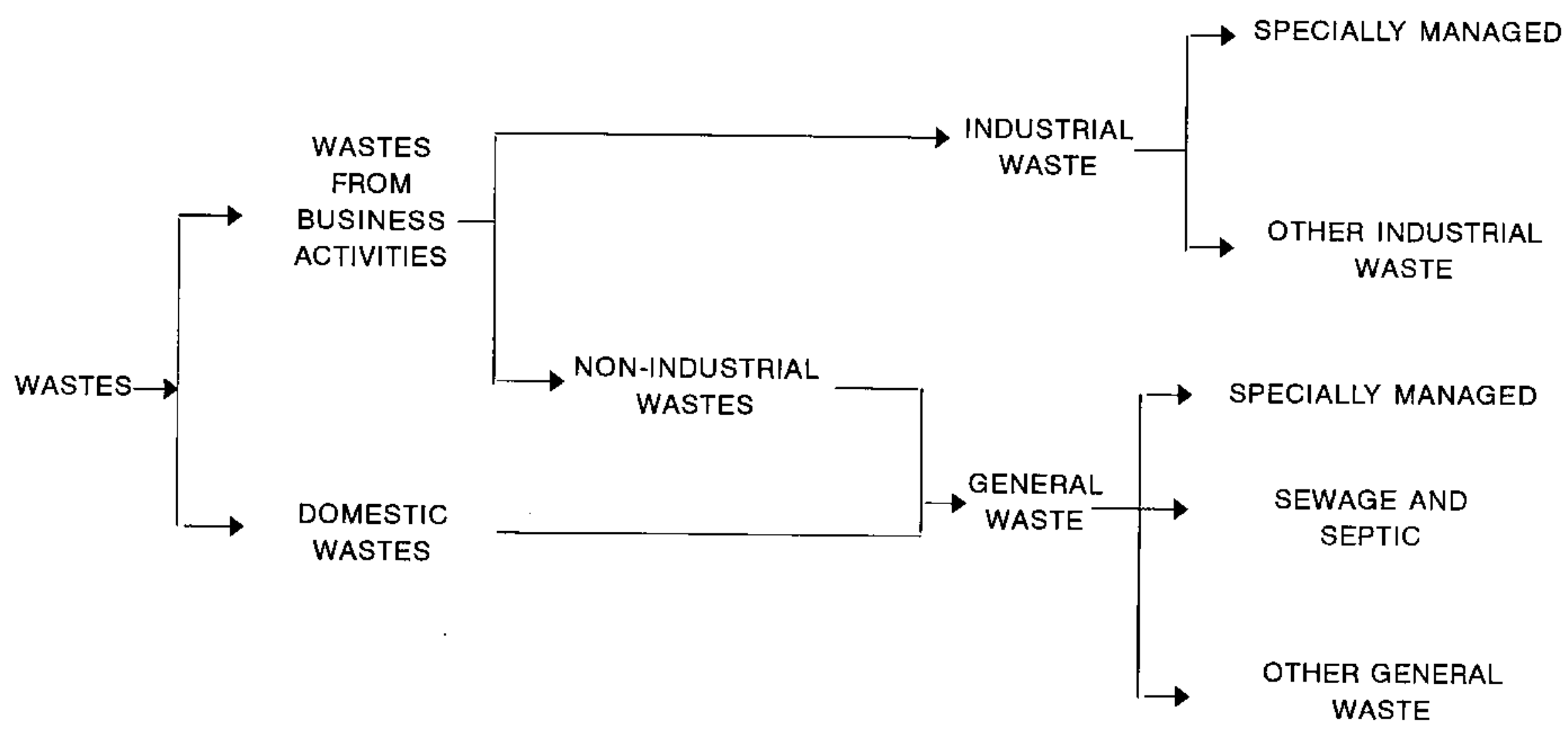

SOURCE: Waste Disposal and Public Cleansing Law, as amended. 
The Waste Disposal Law stipulates that the prefectural governments are responsible for providing technical assistance to municipalities and overseeing the disposal of Industrial Waste within their jurisdictions. Permission must be obtained from the prefectural governor for any private firm to collect, transport, treat, or dispose of Industrial Waste. Firms providing these services for their own benefit; those that collect, transport, and process wastes for reuse and recyc] ing; and any other firms as may be specified by the MHW need not abtain such permission. Businesses must also notify the prefectural governor of any plans to construct or significantly modify an Industrial Waste processing or disposal facility. Such facilities must satisfy the performance standards, and their operators must meet the specified qualification requirements, established by the MHW.

The national government is to perform research and development on waste processing and disposal, and provide technical and financial support to the prefectural and municipal governments. Financial support of municipalities includes subsidies for the construction of waste-processing and disposal facilities. The level of support is determined by cabinet Order. Currently it is 25 percent of the eligible construction costs of combustion facilities, bulky waste shredders, waste-to-energy facilities, materials recovery facilities, and landfills. For municipalities designated as having severe pollution problems, the subsidy can be as high as 50 percent of the eligible construction costs. The national government is also responsible for providing assistance in the financing of these facilities.

The Waste Disposal Law gives the municipalities and perfectures, as appropriate, the right to inspect businesses that collect, transport, treat, or dispose of waste and to "take necessary measures" to eliminate any serious threat or potential threat to the living environment. The Law specifies prison terms and fines for violating any of its specific provisions. The Law also stipulates that operators of waste-processing facilities must meet qualification standards established by the MHW.

In July 1990, the MHW asked the Livinghood Environmental Council, an advisory body to the MHW, to recommend measures for dealing with the effects of the rapid increase in the generation of General Waste (i.e., about a 13 percent increase from 1986 to 1989), the changes in the composition of the General Waste, and the need to site and construct new waste-processing and landfitl capacity. The Council's report was submitted in December 1990. Based on this report, the MHW formulated an amendment to the Waste Disposal Law, which was submitted to the Diet in March 1991. Passage of the bill occurred in October 1991. The purpose of the amendment is to promote waste reduction and recycling; improve waste collection, transport, processing and disposal activities; and ensure the development and construction of needed waste-processing and disposal capacity.

The amendment specifies the additional responsibilities of the public, businesses, and the government. The public, without specific goals or requirements, must make an effort toward waste reduction, use products 
made from recycled materials, sort waste to promote processing and recyciting, and cooperate with the national and local governments' efforts. Businesses, such as manufacturers, must perform internal assessments to avoid future waste processing or disposal problems and cooperate with the national and Tocal governments' efforts to reduce waste and obtain adequate processing and disposal capacity. The national, prefectural, and municipal governments must take measures to ensure adequate processing and disposal of waste. The national government is also charged with the responsibitity of developing data and other information on waste processing.

The amendment also specifies additional planning requirements. Municipal solid waste management plans must now include estimates of General Waste generation and the amounts source-separated, recycled, stored, collected, transported, processed, and disposed of; measures to be undertaken for waste reduction; identification of waste materials suitable for source separation and separate collection; and plans for the construction of new waste-processing facilities (including materials recovery centers and waste-to-energy facilities) and disposal capacity. Municipalities are also empowered with the right to have businesses that generate large amounts of General Waste prepare and submit plans for how they will reduce and recycle General Waste. Other provisions of the amendment require plans from businesses for reducing the amount of Industrial Waste generated and for ensuring sufficient disposal capacity. The MHW is also obligated to compile and disseminate nationwide information on Industrial Waste generation, processing, and disposal.

Four provisions of the amendment are directed at fostering the promotion of waste reduction and recycling. These provisions are as follows: (I) each municipality can establish a "Waste Reduction Promotion Council" composed of citizens, businesspeople, and experts to evaluate methods of reducing waste; (2) a "Waste Reduction Promoter" can be appointed to cooperate with the municipality to promote waste reduction and recycling; (3) recycling dealers can register with the prefectural government and participate in the planning and implementation of municipal recyciing activities; and (4) the fees charged by municipalities must take into account the costs of handling, processing, and disposing of specific waste streams.

To improve waste collection, transport, processing, and disposal activities, the amendment requires stricter controls on waste treatment activities. The amended Waste Disposal Law now distinguishes between businesses that haul waste (i.e., collection or transportation) and businesses that dispose of waste (i.e., process or landfi11). These businesses are also now required to obtain a license, subject to periodic renewa1. This licensing requirement replaces the notification system previously employed and strengthens the standards for businesses performing waste management activities. Stricter standards are also imposed on the procurement of private businesses to perform waste management activities by municipalities. The amendment also requires stricter standards for waste-processing and disposal facilities. All waste-processing and disposal facilities (except for municipal facilities 
that process General Waste, which only require pre-notification) must now be licensed by the prefectural governor. These facilities cannot be operated without an inspection and subsequent approval by the prefectural government. The prefectural government is also responsible for maintaining a record of all disposal sites within its jurisdiction. These records are available to the public. Finally, the amendment strengthens the penal provisions for noncompliance.

The MHW can designate specific types of General Waste that are difficult for municipalities to manage nationwide. The producers of products that upon disposal become designated as such must cooperate with municipalities to implement a suitable means of managing this waste. The MHW may also request from appropriate Ministers that specific products under their jurisdictions be labeled with a description of their contents and the appropriate method of processing and disposal.

Specially Managed Wastes (which includes some hazardous wastes) are now specifically defined in the Waste Disposal Law and include General and Industrial Wastes that might have an adverse affect on human health and the living environment, including explosives, toxics, and infectious wastes. These wastes are subject to stricter waste-management standards. Generators of Specially Managed Industrial Wastes must appoint a qual ified person to be in charge of the management of these wastes. The prefecturat governments may also require firms generating large amounts of Specially Managed Industrial Wastes to prepare plans for the appropriate means of managing such waste. The amendment institutes a manifest system for Specialiy Managed Industrial Wastes, and firms engaged in the management of such Industrial Wastes must be licensed by the prefectural government. New combustion facilities and existing facilities that are designed to separate fly ash from bottom ash must collect the fly ash separately and treat it as Specially Managed Waste.

The MHW can designate "Waste Treatment Public Centers" for the purpose of processing and disposing of Specially Managed Wastes. A fund, financed by businesses, to offset the costs of these centers can be established. The national government is also authorized to provide subsidies and interestfree loans for centers that process and dispose of Specially Managed General Waste from municipalities.

\subsubsection{Regulations on Final Disposal of Waste}

The Waste Disposal Law specifies the standards for landfills, including their design, operation, and maintenance. Wastes that are permitted to be disposed of by ocean dumping are defined in the Waste Disposal Law, while the ocean-disposal methods and the areas within the ocean where dumping is permitted are governed by the Prevention of Marine Pollution and Maritime Disaster Law. Ocean dumping in Japan is treated on an exception basis when there are problems with a particular landfill. All types of General 
Waste may be disposed of in a landfill, however, specifically identified wastes are subject to pre-treatment such as combustion or shredding.

General 1 andfill standards exist for General, Industrial, and hazardous wastes. Individual standards are established for each site and type of waste, such as sludge, cinders, and ash. The standards are established to prevent pollution of groundwater and public waterways; to reduce the volume of waste requiring ultimate disposal; to stabilize the properties of the waste; and to prevent the occurrence of sanitation problems. The standards for the disposal of General Waste are provided in Table 2-6.

Landfills used for the disposal of General Waste must be designed with an impervious liner and a leachate collection and treatment system. Unlined landfills without a leachate collection system are allowed for stable industrial wastes such as plastics, rubber scrap, metal scrap, waste glass and ceramics, and demolition waste.

${ }^{12}$ Shigemento Kajihara, Textbook for the Group Training Course in Solid Waste Management and Night Soil Treatment; Section 4.6, "Regulations on Final Disposal" (Japan International Cooperation Agency). 
TABLE 2-6

JAPANESE STANDARDS FOR DISPOSAL OF GENERAL WASTE

STANDARDS FOR LANDFILL

STANDARDS FOR OCEAN DUMPING

Standards For Wastes

The Sea Areas and the Method of Discharge

COWNON STANDARDS

1. Landilll shall be made in such a way that prevents wastes from scattering or flowing out.

2. Landilt si te shall be constructed in such a way that preservation of the living environment may not be hindered.

3. Landfill shall be fully secured by a fence or other barrier and a sign should be posted identifying such area as a landfill.

4. Necessary measures shall be taken to prevent leachate from landfill site from polluting public water area and groundwater.

5. Necessary measures shall be taken to prevent offensive odor from leaking out

of the landfill site.

Ocean dumping shall be avoided when it is considered that the said wastes can be disposed by landfill.
1. Concentration-type discharge method. ${ }^{1}$ Necessary measures shall be taken to enable the said wastes to precipitate and accumulate on the sea and accumulate on the sea
bottom as soon as possible.

2. Dispersion-type discharge method. ${ }^{2}$ Necessary measures shall be taken to discharge the said wastes little by little, and to enable them to disperse in the sea as soon as possible.

3. Efforts shall be made to avoid places where the growth of marine animals and plants may be hindered by the disposal of wastes.

${ }^{1}$ Concentration-type discharge method: discharge should be made in the form of the specific gravity of 1.2 or more under the sea surface and not in the form of powder.

2Dispersion-type discharge method: discharge should be made under the sea surface during the navigation. 
TABLE 2-6 (CONTINUED)

JAPANESE STANDARDS FOR DISPOSAL OF GENERAL WASTE

STANDARDS FOR LANDFILL
STANDARDS FOR OCEAN DUMPING

Standards For Wastes
The Sea Areas and the Method of Discharge

6. The thickness of a layer of domestic wastes (excluding those of which ignition loss was reduced to $15 \%$ or ignition loss was reduced to $15 \%$ or be covered with approximately $50 \mathrm{~cm}$ of soil and sard.

7. Necessary measures shall be taken to

prevent the growth of rats, mosquitoes,

flies, or other vermin at landfill site.

\section{INDIVIDUAL STANDARDS}

sludge from Septic Tank
1. Landfill shall be conducted after the treatment in one of the fallowing ways:

a. treatment by night soil treatment facilities

b. incineration by incineration facilities

c. mixture of slaked lime at the rate of $0.5 \%$ or more

2. Reclamation on surface water shall be conducted after the treatment in one of the following ways:

a. treatment by night soil treatment facilities

b. incineration by incineration facilities
Only the following are allowed:

a. those in which $0.1 \%$ or mere ferrous sulfate or ferric chloride is mixed b. those which are crushed
Sea Area "C"t ${ }^{3}$. Dispersion-type discharge method. 
TABLE 2-6 (CONTINUED)

JAPANESE STANDARDS FOR DISPOSAL OF GENERAL WASTE

STANDARDS FOR LANDFILL
STANDARDS FOR OCEAN DUMPING

Standards For Wastes

The Sea Areas and the Method of Discharge
Human Excreta

Combustible Wastes

(exclude waste

explosives)

Pesticide rexclude

the one treated by

designated method)

Incombust ible wastes

(exclude sludige from

septic tanks and

human excreta)

Parts made using $\mathrm{PCB}$

whith are incoporated

in air conditioners, TV

sets, electronic ovens

1. Landfill shall be conducted after the treatment in either ways:

a. treatment by night soi

treatment facilities

b. mixture of slaked lime at

the rate of $0.5 \%$ or more

2. Reclamation on surface water shall be conducted after the treatment by night soil treatment facilities.

No pre-trestment required.

Ditto

Dit to

Ditto

Ban on landfilll.
Source: "Solid Waste Management and Night Soil Treatment," Section 4.6, Regulations on Final Disposal.




\section{REFERENCES}

Clean Japan Center. Cabinet Order and Ministerial Ordinances Under the Law for Promotion of Utilization of Recyclable Resources, 1991. (English Translation)

Clean Japan Center. Law for Promotion of Utilization of Recyclable Resources, 1991. (English Translation)

Environmental Information Center. Environmental Protection Policy in Japan. Environmental Information Center under the supervision of the Japanese Environmental Agency, 1991. (English)

Government of Japan. Basic Law for Environmental Pollution Control. Law No. 132 of 1967 Diet, as amended by Law No. 132 of 1970 Diet, Law No. 88 of 1971 Diet, Law No. 111 of 1973 Diet, Law No. 84 of 1974 Diet, and Law No. 78 of 1983 Diet.

Government of Japan. Cabinet Order for Implementation of the Waste Management Law. Cabinet Order No. 300, September 23, 1971, as amended in $1972,1974,1976,1980$, and 1983.

Government of Japan. Pollution-Related Health Damage Compensation Law. Law No. 111 (October 5, 1973), as amended by Law No. 85 of 1974 Diet, Law No. 10 of 1978 Diet, Law Nos. 16 and 78 of 1983 Diet, and Law No. 97 of 1987 Diet.

Government of Japan. Promotion of Utilization of Recyclable Resources Law, April 1991 .

Government of Japan. Waste Disposal and Public Cleansing Law. Law No. 137 of 1970 Diet, as amended by Law No. 71 of 1974 Diet, Law Nos. 47 and 68 of 1976 Diet, Law No. 43 of 1983 Diet, and Law No. 91 of 1991 Diet.

Hashimoto, Michio. Economic Development and the Environment: The Japanese Experience. Ministry of Foreign Affairs, April 1992. (English)

Japanese Environmental Agency. Quality of the Environment in Japan 1992. White paper on the environment for fiscal year 1991, submitted to the 123rd session of the Diet, May 26, 1992. (English Translation)

Japanese Environmental Agency, Water Quality Bureau. Water Quality Management in Japan, April 1992. (English)

Kajihara, Shigemento. Textbook for the Group Training Course in Solid Waste Management and Night Soil Treatment; Section 4.6, "Regulations on Final Disposal." Japan International Cooperation Agency, no date.

Ministry of Health and Welfare. The Outline of Amendment Bill of Waste Disposal and Public Cleansing Law, 1992. (English) 
Ministry of Health and Welfare. The Outline of Amendment Bill of Waste Disposal and Public Utility Law, 1992. (English)

Plastic Waste Management Institute. Plastic Waste: Disposal and Recycling, Past, Present and Future in Japan. Tokyo: Plastic Waste Management Institute, Surveys \& Public Relations Dept., 1991. (English)

Tsuru, Shigeto and Weidner, Helment (eds.). Environmental Policy in Japan. Ed. SigmaBohn, 1989. (English)

Yumoto, Noboru. The Law for Promotion of Utilization of Recyclable Resources, October 1992, publication pending. (English) 
3.

NATIONAL WASTE GENERATION, TREATMENT, AND DISPOSAL STATISTICS

The Japanese, through a combination of public policy, private market conditions, and geographic necessity, practice integrated municipal solid waste (MSW) management, defined in the U.S. EPA's Decision-Makers' Guide to Solid Waste Management as:

A practice of using several alternative waste management techniques to manage and dispose of specific components of the municipal solid waste stream. Waste management alternatives include source reduction, recycling, composting, energy recovery and landfilling.

The Japanese public policies for MSW management are delineated in the environmental legislation and cabinet orders discussed in Section 2 of this report. In addition, the Ministry of Health and Welfare (MHW) publishes a number of guidelines to assist municipalities in the implementation of their MSW management programs. The Guidelines of Solid Waste Management, published by the MHW in the late 1970s, provides the planning requirements and minimum technical specifications for waste treatment facilities (i.e., facilities to separate, combust, compost, shred, bail, and/or physically, chemically, or biologically change the refuse until it is suited for recycling or landfill disposal). 14 The approach of MSW management in Japan as stated in these guidelines is as follows:

The basic concept of refuse treatment consists of recyciing discharged refuse into usable resources, reusing such resources as much as possible, and then treating or disposing the unusable portion, into a sanitary condition. Considering the difficulty of procuring land or seaside areas for such a purpose as a refuse disposal site it will be necessary to minimize the volume of collected refuse for treatment or disposal. 15

This approach clearly incorporates waste reduction, reuse and recycling, combustion, and disposal, and thus represents integrated municipal solid waste management.

The Japanese have not defined a specific hierarchical preference for these waste management options. However, in marked contrast to the U.S. approach, the Japanese system relies heavily on waste combustion with or without energy recovery. Specifically, the MHW's guidelines state:

${ }^{13}$ U.S. Environmental Protection Agency, Decision-Makers' Guide to Sol id Waste Manaqement (November 1989), p. 151.

${ }^{14} \mathrm{Japan}$ Institute of Infrastructure, Gujdelines of Solid Waste Management (March 1982), p. 3.

${ }^{15}$ Guidelines of Solid Waste Management (1982), p. 1. 
Among the various treatment methods, incineration permits the highest reduction of volume while at the same time stabilizing putrefactive organic matter. In general, therefore, combustible refuse will principally be burned and then finally disposed of.

Current policy still emphasizes incineration/waste-to-energy as a primary means of treating MSW. For example, the Annual Report on Health and Welfare 1990-1991, states:

MSW volume can be slashed by crushing [shredding] or compressing to some extent, but reduced substantially by incineration in terms of weight and cubic volume. Therefore, planned construction of or improvements in incineration facilities must be encouraged.... reusable waste such as iron and aluminum are encouraged to be collected even [during] midstage treatment such as crushing and incineration to the extent possible.

The Japanese heavy reliance on incineration/waste-to-energy can be explained partially by the country's severe shortage of landfill space and the Japanese desire to sanitize and sterilize the waste.

National and local governments are now more actively participating in and promoting recycling, as exemplified by the 1991 passage of the Recycling Law and the 1991 amendment to the Waste Disposal Law. This has been largely due to the rapid increase (approximately 3.6 percent annually) in waste generation since 1985. Increased governmental involvement in recycling is also due to the yen's appreciation, which has made imported virgin materials less costly, resulting in a decrease in the relative value of secondary materials.

The solid waste policy and market conditions that exist in Japan can be attributed largely to the country's lack of natural resources coupled with its rapid change, over the past approximately 50 years, from an agricultural society to one of the world's leading industrial countries. Japan's population, equal to approximately one-half the population of the United States, lives and works in a country about the size of California. Further, only about one-fifth of this land area is habitable. This limited land availability results in shortages of suitable land for landfills. In addition, the high costs of 1 and near population centers make landfilling relatively expensive. These factors, coupled with opposition from residents living near proposed new sites (i.e., the "not

${ }^{16}$ Guidelines of Solid Waste Manaqement (1982), p. 2.

${ }^{17}$ Japanese Ministry of Health and Welfare, Annual Report on Health and Welfare 1990-1991 (January 1992), p. 37.

${ }^{18}$ Annual Report on Health and Welfare 1990-1991 (1992), p. 18. 
in my backyard" syndrome), ${ }^{19}$ has made the preservation of 1 andfill capacity the primary criterion in the formulation of Japan's MSW management policies. Although Japan has limited natural resources, ${ }^{20}$ the primary purpose of promoting reuse and recycling in Japan is not to conserve resources or reduce imports, but rather, to reduce the volume of waste going to the landfill.

Section 3.1 addresses Japanese MSW generation, collection, and treatment. The methods and impacts of private-sector recycling are discussed in Section 3.2. This information is combined, and estimates of total discards and recycling rates are presented, in Section 3.3. Aggregate costs and sources of funds to manage MSW are presented in Section 3.4.

\subsection{MUNICIPAL SOLID WASTE GENERATION, COLLECTION, AND TREATMENT}

"Discards," as the term is used in this report, refers to all materials considered used and spent by residential and commercial generators. That which is discarded (whether recyclable or nonrecyclable) and treated either directiy or indirectly (i.e., through municipal-private agreements) by a municipality is referred to as municipal solid waste (MSW). Such treatment can include municipal recycling, landfilling, incineration, and composting. Discards which are diverted from the waste stream (and therefore not considered MSW) are so diverted through private recycling (such as "group recycling," recycling dealers, garage sales, flea markets, returns to retail outlets, donations, etc.). Group recycling, considered a private fund-raising activity, is increasingly being subsidized by municipalities. However, in cases where such subsidization occurs, group recycling is nevertheless considered private recycling, rather than municipal recycling. Municipal recycling is the recovery of recyclable MSW and can occur through source-separation programs, mixed-waste processing, materials recovery centers, or post-combustion materials recovery. Therefore, when "MSW treatment" is discussed in this report, it does not include discarded materials that have not entered the waste stream.

Each year the MHW publishes comprehensive national statistics on MSW generation and the treatment methods extant in Japan. The information in these documents is compiled from data reported by municipalities which together represent 99.9 percent of the population. The most recent report was published in December 1991 and reflects data from ApriT 1, 1989,

${ }^{19}$ Annual Report on Health and Welfare (1992), p. 24.

${ }^{20}$ Japan imports more than 85 percent of its oil, coal, natural gas, iron ore, copper, lead, tin, aluminum, and nickel. It is also one of the world's leading importers of cotton, wool, and lumber. 
through March 31, 1990, i.e., the Japanese fiscal year 1989 (FY89).21 The information presented below was obtained from the FY89 MHW report and deals exclusively with MSW, i.e., discards treated by municipa] governments.

\subsubsection{MSW Generation}

During FY89, 48.7 million tonnes ${ }^{22}$ of MSW were generated in Japan. This tonnage does not include discarded materials that were diverted from the waste stream for reuse or recycling, nor does it include the approximately 1.3 million tonnes that were reported to have been disposed of directly by individuals (e.g., disposed of down kitchen sinks, burned, buried, or composted in backyards). This does, however, include materials separated from MSW for reuse or recycling by municipalities after collection. Historical generation rates from FY83 through FY89 are provided in Table 3-1.

There is no published national "average" waste composition for Japan. Specific municipal waste composition data is available for total MSW treated by municipalities as well as for each sorted component of their MSW streams (e.g., typically combustibles and noncombustibles, and in some cases also glass, metals, paper, and/or textiles). Since the Japanese waste composition data does not include discarded materials that are diverted from the waste stream, which are commonly included in U.S. composition data (e.g., glass and newspapers), direct comparisons between waste compositions of U.S. and Japanese cities can be misleading. In general, however, it can be concluded from the waste composition data that MSW in Japan includes virtually no yard waste and a relatively high proportion of food waste. Examples of specific city MSW compositions are provided in Section 4 of this report.

\subsubsection{MSW Collection}

Municipalities are responsible for all MSW management within their jurisdictions, and they are legally required to directly or indirectly collect MSW from all residences within their jurisdictions. In FY89, approximately 62 percent of the MSW collected from residences was collected directly by the municipalities, while the balance was collected indirectly, i.e., by private firms, under contract to municipalities. ${ }^{23}$ Over the past decade the amount of residential MSW collected by private

${ }^{21}$ Japanese Ministry of Health and Welfare, Japanese Disposal of Waste - 1989 (Water Supply and Environmental Sanitation Department, Office of Environmenta1 Maintenance, December 1991).

${ }^{22}$ Metric units are used in this report. A short ton $(2,000$ pounds) is 1.1 times the number of metric tonnes.

${ }^{23}$ Japanese Disposal of Waste - 1989 (1991), p. 37. 
TABLE 3-1

MUNICIPAL SOLID WASTE GENERATION IN JAPAN

\begin{tabular}{|c|c|c|c|c|c|c|c|}
\hline & FY1983 & FY1984 & FY1985 & FY1986 & FY1987 & FY1988 & FY1989 \\
\hline \multicolumn{8}{|l|}{ POPULATION ( 1,000 persons $)$} \\
\hline $\begin{array}{l}\text { Total Population } \\
\text { Population in Disposal } \\
\text { Districts }\end{array}$ & $\begin{array}{l}119,733 \\
119,210\end{array}$ & 120,444 & 121,267 & 122,000 & 122,185 & 122,648 & 123,137 \\
\hline MSW ( 1,000 tonnes/year) & & & & & & & \\
\hline $\begin{array}{l}\text { Planned Collction } \\
\text { Carried-In Waste }\end{array}$ & $\begin{array}{r}33,773 \\
6,733 \\
\end{array}$ & $\begin{array}{r}34,580 \\
6,515 \\
\end{array}$ & $\begin{array}{r}35,383 \\
6,147 \\
\end{array}$ & $\begin{array}{r}36,288 \\
6,670 \\
\end{array}$ & $\begin{array}{r}38,060 \\
6,748 \\
\end{array}$ & $\begin{array}{r}39,723 \\
7,221 \\
\end{array}$ & $\begin{array}{r}41,602 \\
7,054 \\
\end{array}$ \\
\hline Total MSW & 40,506 & 41,095 & 41,530 & 42,958 & 44,808 & 46,944 & 48,656 \\
\hline \multicolumn{8}{|l|}{ MSW GENERATION RATES } \\
\hline $\begin{array}{l}\text { Per-Capita MSW Generation } \\
\text { (grams per person per day) }\end{array}$ & 931 & 937 & 942 & 967 & 1,006 & 1,050 & 1,035 \\
\hline $\begin{array}{l}\text { Per-Capita MSW Generation } \\
\text { (pounds per person per day) }\end{array}$ & 2.05 & 2.06 & 2.07 & 2.12 & 2.21 & 2.31 & 2.39 \\
\hline
\end{tabular}

Sources: "Plastic Wastes," Plastic Waste Management Institute, 1991 (p. 83); and "Japanese Disposal of Waste -Fiscal Year 1989, "Ministry of Health \& Welfare, December 1991 (p. 26). 
firms on behalf of municipalities has been gradually but steadily increasing.

There is no legal requirement for municipalities to collect or dispose of Commercial MSW (i.e., General Waste, exclusive of sludge and septic waste, generated by offices, hotels, restaurants, schools, government buildings, etc.) generated within their jurisdictions. Rather, each municipality decides whether it will collect Commercial Waste or direct businesses to either haul their own waste or contract with licensed haulers to pick up their waste. There are some intermunicipal agreements whereby Residential MSW is processed and/or disposed of, along with residues and ash, in other jurisdictions. Although there are many examples of cooperation between jurisdictions (as seen in some of the case studies of selected cities) Japanese communities do experience interjurisdictional conflicts similar to those in the U.S. In 1971 severe interjurisdictional disputes occurred among Tokyo's various wards, which are referred to as the "Tokyo garbage wars. "24 Today there is an "invisible garbage war" between Tokyo and its neighbors. Many communities surrounding Tokyo have passed "Prior Consultation Ordinances," which require prior approval to dispose of imported waste within their jurisdictions. ${ }^{25}$

Although door-to-door MSW collection in residential neighborhoods sometimes occurs, "station-based" collection, whereby waste is brought by residents to designated collection points (i.e., stations), is far more prevalent in Japan. These stations are within walking distance of every residence. Typically 15 to 40 households utilize a single station.

Separation of MSW into combustible and noncombustible components is common in Japan, with over 80 percent of the municipalities requiring at least this degree of source separation. ${ }^{26}$ Although the number of municipal programs that include recyclable materials separation is growing, the number is still relatively small (i.e., less than 30 percent of municipalities). Many of the cities that do not require any level of source separation are the largest in Japan, such as Kobe, Osaka, Kyoto, Yokohama, and Kawasaki.

Noncombustible MSW often includes plastics. The reasons for classifying plastics as noncombustible is that many of the 1,941 incineration/wasteto-energy facilities in Japan were built during the 1970s and early 1980s without acid gas controls and were designed for combusting MSW with a relatively low heating value. The newer waste-to-energy facilities are being designed to combust most plastics.

\footnotetext{
24Machida City "Summary of Sanitation Operations - Fiscal Year 1990" (October 1, 1991), p. 3 .

${ }^{25} \mathrm{Dr}$. Sukehiro Gotoh, Director of Social and Environmental Systems Division, Japan National Institute for Environmental Studies, and Dr. Alan S. Cohen, discussion (0ctober 12, 1991).

${ }^{26} \mathrm{Plastic}$ Waste Management Institute, Plastic Wastes (1991), p. 88.
} 
In addition to the routine MSW collections, most municipalities have periodic pick-ups, or pick-up upon request, for bulky wastes. Household hazardous waste collection days are not common, but some municipalities collect dry cell batteries, thermometers, and fluorescent 1ightbulbs on a regular basis.

Examples of specific municipal collection programs for source-separated recyclables are described in Section 4 of this report.

\subsubsection{MSW Treatment}

of the 48.7 million tonnes treated by municipalities in FY89, approximately 74 percent was combusted with and without energy recovery, while 23 percent was sent to landfill (exclusive of ash), 3 percent was municipally recycled, and approximately 0.1 percent was composted or used as animal feed. This breakdown clearly evidences Japan's national policy of combusting the combustible fraction of the MSW stream, which was begun in the 1970s.

The residues from MSW processing and combustion were eventually sent, along with noncombustible waste, to landfills for disposal. In total, approximately 17 million tonnes, or 35 percent, of the MSW treated by municipalities in FY89 was landfilled. Because of combusting, shredding, and compacting, the MSW volume reduction is significantly greater than its weight reduction. Historical data on the disposition of MSW is provided in Table 3-2, while Figure 3-1 provides a flow diagram showing the quantities of MSW treated in FY89, and the methods of treatment employed.

Bulky, noncombustible, and source-separated MSW are processed to recover reusable and recyclable materials such as ferrous metals, aluminum, glass, newspapers, magazines, corrugated cartons, clothing, furniture, and appliances. Of the 48.7 million tonnes of MSW treated by municipalities in FY89, only $1.5 \mathrm{milli}$ ion tonnes, or 3.1 percent of these materials, were recovered from the MSW stream for reuse or recycling. As indicated previously, municipally sponsored recycling reflects only a fraction of all the recycling that occurs in Japan. Section 3.2, below, addresses private-sector recycling in detail.

\subsection{PRIVATE-SECTOR RECYCLING}

In the U.S., recycling is typically conducted through municipal recycling programs; hence, Americans tend to think of recycling as a municipal function. However, this is not the case in Japan, where the bulk of recycling occurs through private-sector endeavors.

Historically, there has been a strong private market for secondary goods such as old newspapers, magazines (including the telephone-book-sized "comic books" that are very popular in Japan), corrugated cartons, steel, aluminum, textiles (e.g., used clothing for sale in other, less developed Pacific rim countries), and glass. There are many ways by which such 
TABLE 3-2

METHODS OF TREATING MUNICIPAL SOLID WASTE IN JAPAN (\% of total MSW treated)

\begin{tabular}{|c|c|c|c|c|c|c|c|}
\hline TREATMENT METHOD & FY1983 & FY1984 & FY1985 & FY1986 & FY1987 & FY1988 & FY1989 \\
\hline \multirow{3}{*}{$\begin{array}{l}\text { Incineration } \\
\text { Composting \& Animal } \\
\text { Feed } \\
\text { Landfill (direct) } \\
\text { Other* }\end{array}$} & 67.6 & 69.1 & 70.6 & 71.9 & 72.6 & 72.8 & 73.9 \\
\hline & $\begin{array}{r}0.2 \\
29.6 \\
2.6 \\
\end{array}$ & $\begin{array}{r}0.2 \\
28.0 \\
2.7 \\
\end{array}$ & $\begin{array}{r}0.2 \\
26.4 \\
2.8 \\
\end{array}$ & $\begin{array}{r}0.1 \\
24.7 \\
3.3 \\
\end{array}$ & $\begin{array}{r}0.1 \\
23.5 \\
3.8 \\
\end{array}$ & $\begin{array}{r}0.1 \\
23.0 \\
4.1 \\
\end{array}$ & $\begin{array}{r}0.1 \\
21.7 \\
4.3 \\
\end{array}$ \\
\hline & 100.0 & 100.0 & 100.0 & 100.0 & 100.0 & 100.0 & 100.0 \\
\hline
\end{tabular}

* Includes residue from processed recyclable materials that was ultimately landfilled.

Sources: $\quad$ "Plastic Wastes," Plastic Waste Management Institute, 1991 (p. 83); and "Japanese Disposal of Waste -- Fiscal Year 1989," Ministry of Health \& Welfare, December 1991 (p. 26). 
FIGURE 3-1: NATIONAL MSW WASTE FLOW DIAGRAM--FISCAL YEAR 1989 (Thousands of Tonnes per Year)

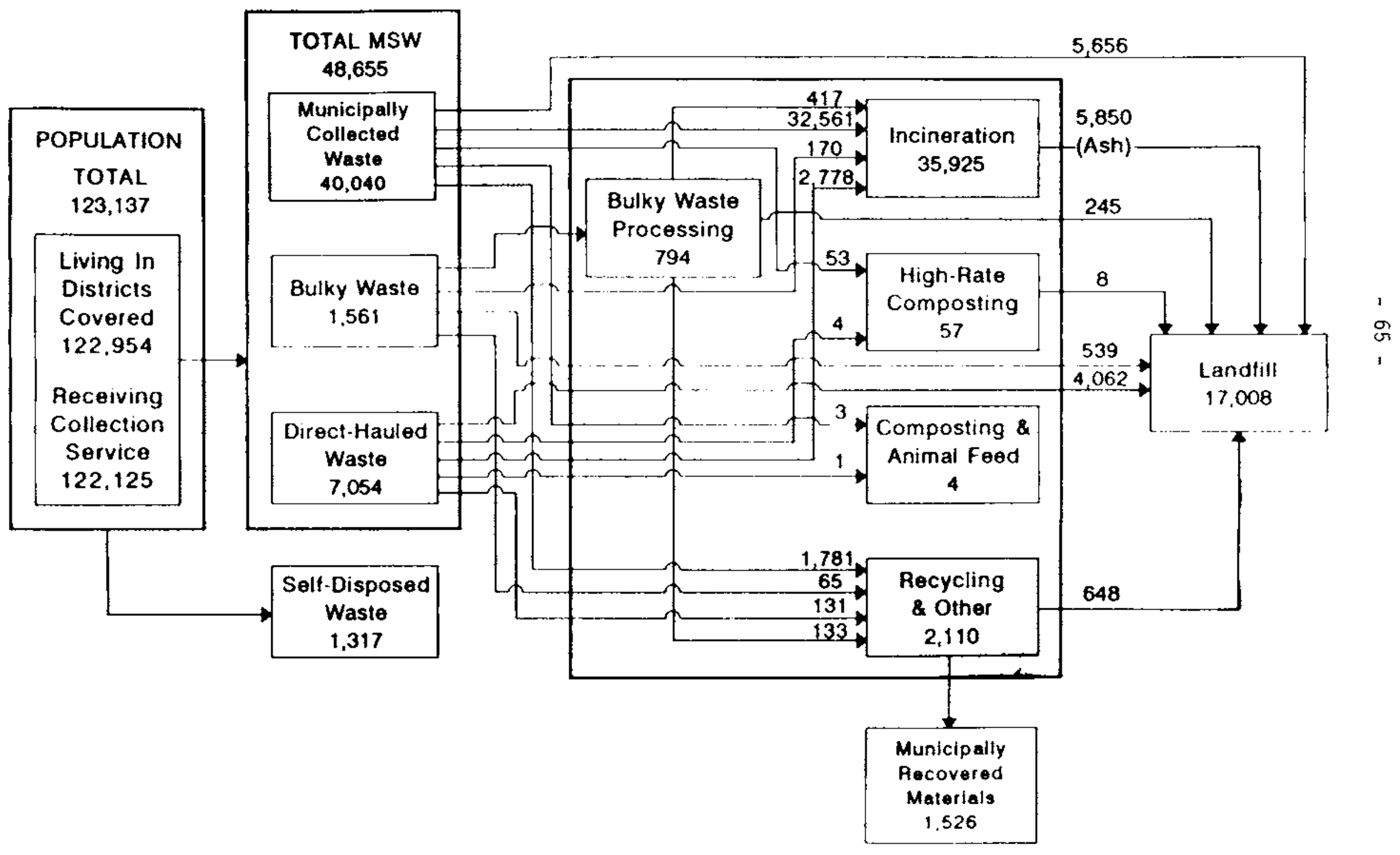


materials are privately collected, including returning reusable glass bottles to stores or distributors, group recycling, private recycling dealers (often referred to in the U.S. as junk dealers or scavengers) including the "tissueman", and resale outlets. (The "tissueman" [in Japanese, "chirigami-kokan"] drives slowly through residential areas announcing his arrival by bullhorn. He usually collects old newspapers, magazines, and used textiles from households in exchange for toilet and tissue paper. In some residential locations where tissuemen are no longer active, newspaper companies have taken up the task of collecting old newspapers. The homeowner is given a bag, often printed with the name of the newspaper, in which to package their old newspapers. These packages are placed on the curb and picked up by the newspaper companies on a routine schedule.)

Many products (primarily beer, sake, and 1iquor, and to a Tesser extent milk and soy sauce) are sold in reusable glass botties.27,28 A relatively large number of bottles are recycled each year in Japan. The Clean Japan Center reports that 80.5 percent of the refillable bottles were returned in 1989. ${ }^{29}$ The high rate of return of these bottles occurs in part because many of the products sold in these bottles are distributed in large quantities to restaurants, hotels, and bars where the empty bottles are picked up by the distributer. Similarly, many liquor stores and some milk companies make deliveries to households and pick up the empty bottles in the process.

The private market for secondary goods is supported by volunteer organizations that raise money for the community (e.g., local PTA organization raising money for school activities) by establishing collection points, i.e., drop-off centers, for community residents to bring secondary materials to for recycling. ${ }^{30}$ The volunteer organizations have agreements with private recycling dealers to pick up these materials at predetermined times, and the recyciing dealers pay these organizations for the materials received. Often a recycling dealer only collects specific materials, therefore, it is common to have many dealers working with a given volunteer organization. This type of recycling in Japan is known as "group recycling". Recycling dealers also

${ }^{27} \mathrm{~A} 1$ though there is no "bottle bill" in Japan, there is a variable deposit charge range from 6 to 35 yen ( 4 to 26 cents), depending on the size and type of bottle.

${ }^{28}$ According to $\mathrm{Mr}$. Sato of the Japan Used Can Treatment Association, and $\mathrm{Mr}$. Fujimeto of the Clean Japan Center (discussion with Dr. Alan S. Cohen, October 16, 1992), the attributes and appropriateness of a "bottle bill" in Japan are currently being evaluated.

${ }^{29}$ Clean Japan Center. Recycling Guide for Beginners (1992), p. 30.

${ }^{30}$ This is similar to the "paper drives" that used to be conducted in the U.S, to raise money for the Boy and Girl Scouts, religious groups, and other nonprofit organizations. 
collect recyclable materials directly from households and commercial establishments.

Because of the drop in market prices for secondary materials, caused principally by the appreciation in the yen, the ability to run a profitable recycling dealership or to raise sufficient money for the volunteer groups has threatened some group recycling activities. As a result many local governments are now providing guidance in establishing volunteer groups and providing financial incentives to maintain and increase the effectiveness of existing groups. In addition, some municipalities are providing price supports to recycling dealers to make up for lost revenues from the sale of the secondary materials.

Japan does not have many vehicles comparable to the U.S.'s Salvation Army or Goodwill Industries; thrift, resale, and consignment shops; garage and estate sales; and flea markets by which to divert clothing, furniture, appliances, kitchenware, and other household discards from the MSW stream. In part, these types of resale outlets are not very prevalent in Japan because the Japanese have a greater aversion to using second-hand goods than do Americans. The national government and many municipalities are, however, promoting such ideas as using goods longer; giving usable but unwanted goods to others; and holding "garage sales, "flea markets, or bazaars as ways to increase the recycling of discards. Japanese officials often cite the success of such U.S. programs in their educational materials promoting these kinds of activities.

\subsection{ESTIMATED TOTAL DISCARDS AND RECYCLING RATES}

Because the mechanisms for recycling previously discussed are carried out by citizens and private businesses, statistics on the total quantity of discards diverted from the MSW stream are not generated by local or national Japanese governments. However, a number of studies designed to estimate the total quantity and types of discards (i.e., MSW and privately recycled discards) have been conducted in Japan. Three such studies were conducted in the mid-1980s: one for the Mequro
Ward of Tokyo, one for Okayama City, and one for Matsudo City. ${ }^{31,32,33}$ Each of these studies estimated the amount of private-sector recycling from both residential and commercial sources. The Matsudo City study is discussed in more detail in Section 4.2 .

\footnotetext{
${ }^{31}$ Meguro Recycling Project Group, Basic Principles of Recycling Project in Meguro-ku, March 1989.

${ }^{32} 0$ strand, Inc., LTD, Matsudo City - Basic P1an for General Waste Disposal (Waste Edition) (Department of Sanitation, March 1988).

${ }^{33}$ Okayama Residential Waste Management Plan (March 1988).
} 
These studies may overstate the rates of private-sector recycling occurring in these communities. The rates may be high because many of the participants in the studies were municipal employees or members of civic groups and because "in comparison with the average household, many households in the survey are making an effort to reduce and recycle properly." 34 The bias of the survey technique is somewhat counterbalanced by the recent municipal and national government programs to promote recycling. Therefore, the results of these studies provide reasonable estimates of recycling rates in Japan today.

Much of the growth in MSW generation in Japan since 1986 has been from the commercial sector, reflecting in part office automation (e.g., computers, xerox machines, fax machines). Therefore, the estimates provided below may understate the percent contribution of commercial discards to total discards. Finally, to apply the 1986 recycling rates derived from these studies to the nationa] FY89 MSW statistics, it is assumed that the Japanese have been able to achieve rates of recycling for office paper that are similar to the high rates of recycling achieved for newspapers, magazines, and corrugated cardboard from commercial establishments.

Meguro, one of Tokyo's 23 administrative wards, had a 1990 population of about 242,000 persons living in a 14.7-square-kilometer area, i.e., a population density of 16,450 persons per square kilometer (about 42,600 persons per square mile). Okayama City, on the other hand, had a 1990 population of about 587,000 people living in a 513-square-kilometer area, i.e., a population density of on $7 y$ 1,140 persons per square kilometer (about 2,960 persons per square mile). Matsudo City had a 1990 population of just over 450,000 persons and a population density of 7,340 persons per square kilometer (about 19,000 persons per square mile). (Note: For a comparison of selected U.S. and Japanese city population densities, see Appendix D.)

The 1986 estimated percentages, or levels, of private-sector recycling, exclusive of self-disposed waste, from these studies are 18.2 percent in the Meguro Ward, 12.7 percent in Okayama, and 25.7 percent in Matsudo. Based on these three studies, there appears to be no relationship between the level of private-sector recycling and either population density or total population. However, if the rates achieved by these communities are representative of private-sector recycling in Japan as a whole, then it can be concluded that private-sector recycling in Japan ranges between 12.7 and 25.7 percent.

According to the MHW data, Japan generated 48.7 million tonnes of MSW in FY89. If it is assumed that the above private-sector recycling rates are representative of Japan as a whole, and if the assumed nationwide range of 12.7 to 25.7 percent is applied to the MHW's FY89 MSW generation figure, the resultant range of total discards (exclusive of self-disposed waste) generated in Japan during FY89 is 55.7 to $65.5 \mathrm{million}$ tonnes. Based on

${ }^{34}$ Ostrand, Inc., LTD, Matsudo City - Investiqation of Weights of Household Waste: Report (Department of Sanitation, March 1987), p. 12 . 
this data, the total rate of combined municipal and private-sector recycling of both residential and commercial discards in Japan (exclusive of self-disposed wastes) is estimated to range between 15 and 28 percent.

Table 3-3 provides a summary of estimated FY89 total discards and their disposition statistics assuming both high (i.e., 25.7 percent) and low (i.e., 12.7 percent) rates of private-sector recycling, as well as a summary of total MSW disposition statistics. The data in Table 3-3 is shown pictorially in Figure 3.2. Note that the "Actual MSW" column is the MHW data provided in Figure 3-1. This data is repeated in both "Estimated Discard" columns. Table 3-4 depicts the calculations performed in arriving at these data. As shown in Table 3-3 and Figure 3-2, of the estimated 55.7 to 65.5 million tonnes of residential and commercial discards generated in Japan during FY89, exclusive of self-disposed waste, an estimated 55 to 64 percent was combusted; 15 to 28 percent was recycled (only 2 to 3 percent through municipal recycling activities); and 17 to 20 percent was landfilled. Including ash disposal, 26 to 30 percent, by weight, of the gross discards were landfilled. The estimated annual percapita generation rate for total residential and commercial discards, exclusive of self-disposed waste, ranges between 0.45 and 0.54 tonnes per person per year (approximately 2.7 to 3.2 pounds per person per day).

of particular interest is that this impressive recycing rate range reflects an extremely high capture rate for newspapers, magazines, and reusable bottles. It should also be noted that the Japanese are achieving these rates of recycling with very little yard waste in their discards.

Various trade associations, as well as the Japanese national government, report utilization rates for waste paper of about 48 percent, for steel cans of about 44 percent, for aluminum cans of about 43 percent, and for glass cullet of about 49 percent. ${ }^{37,38}$ How can these high utilization rates be reconciled with the recycling rates estimated using the Meguro, okayama, and Matsudo studies? The associations' reported utilization

${ }^{35}$ Hypothetically, if yard waste were added to the Japanese gross discards estimate such that it would represent 18 percent of total discards, then the per-capita daily waste generation rate would range between 3.3 and 3.9 pounds.

${ }^{36}$ Hypothetically, if yard waste were added to the gross discards estimate such that it would represent 18 percent of total discards, and 70 percent of the yard wastes were recycled, then the equivalent recycling rate would range between 25 and 36 percent.

\section{${ }^{37}$ plastic Wastes (1991), p. 174.}

${ }^{38}$ Differing methods were used to determine the recycling or utilization rates for these materials. In addition, there is some disagreement among professionals in Japan regarding the types and sources of materials used to calculate each of these rates. For example, the recycling rate for steel cans may include more than just steel can scrap in the numerator (e.g., shredded refrigerators and bicycles, etc., in addition to steel cans), while it only includes steel can production in the denominator. If so, this rate would overstate steel can recycling. 
TABLE 3-3

TOTAL DISCARDS/MSW DISPOSITION AND STATISTICS

FISCAL. YEAR 1989*

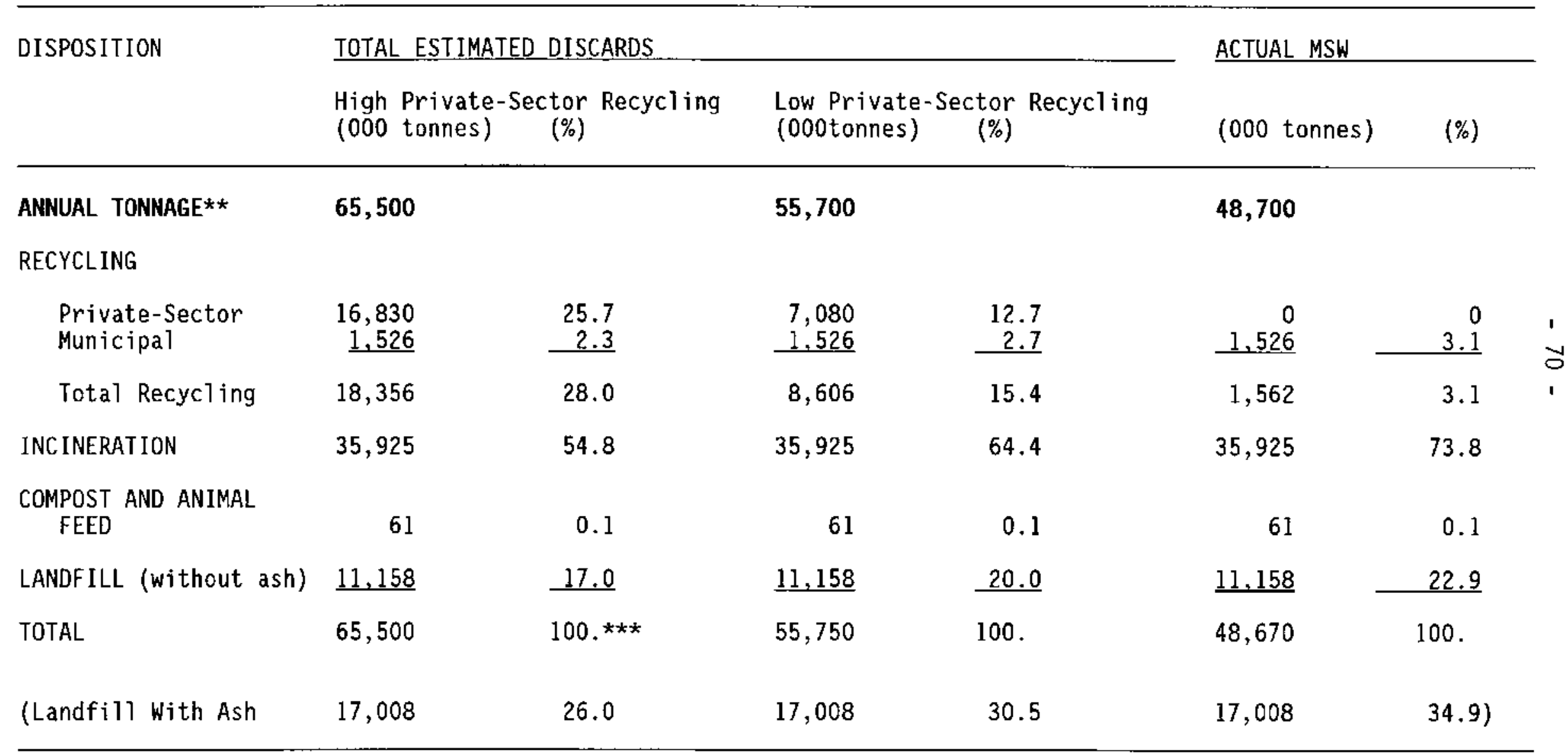

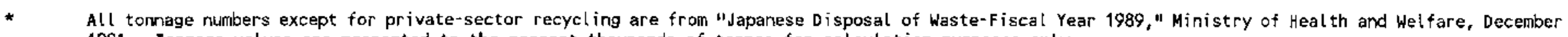
1991. Tonnage values are presented to the nearest thousands of tones for calculation purposes only.

** Annual tonnage estimates are rounded to the nearest hundred thousands of tonnes.

*** Percentages do not add due to rounding. 
FIGURE 3-2: TOTAL DISCARDS/MSW DISPOSITION AND STATISTICS - FISCAL YEAR 1989 Thousands of tonnes

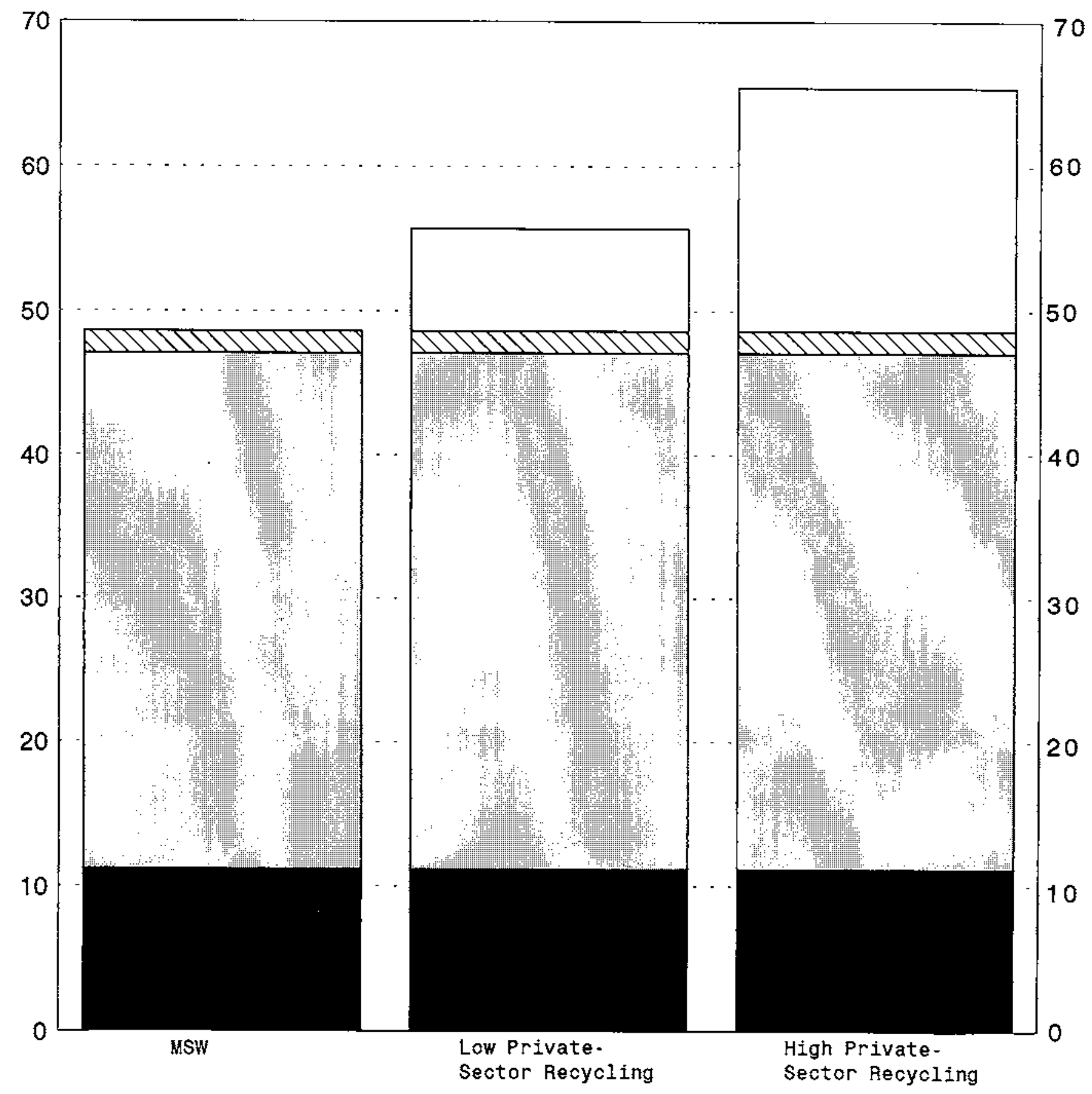

$\square$ Private Recycling
$\nabla_{\text {Municipal Recycling }}$
$\square$ Incineration
$\square$ Landfill (without ash)


TABLE 3-4

METHODOLOGY FOR ESTIMATING TOTAL DISCARDS AND PRIVATE-SECTOR RECYCLING RATE

\section{Algebraic Equations}

$$
\begin{aligned}
& \mathrm{TD}=(\mathrm{MSW}) /(1-R) \\
& \mathrm{PR}=(\mathrm{TD})(\mathrm{R})
\end{aligned}
$$

where:

$\begin{array}{ll}\text { TD } & =\text { Total Discards (tonnes) } \\ \text { MSW } & =\text { Municipal Solid Waste (tonnes) } \\ R & =\text { Private-Sector Recycling Rate (decimal fraction) } \\ \text { PR } & =\text { Private-Sector Recyclables (tonnes) }\end{array}$

High Private-Sector Recycling

Given:

$$
\begin{aligned}
\text { MSW } & =48,655 \text { for FY89 and } \\
R & =.257
\end{aligned}
$$

then:

$$
\begin{aligned}
\mathrm{TD} & =(48,655) /(1-.257)=65,484 * 65,500 \\
\mathrm{PR} & =(65,484)(.287)=16,830 * 16,800
\end{aligned}
$$

Low Private-Sector Recycling

Given:

$$
\begin{aligned}
\text { MSW } & =48,655 \text { for } F Y 89 \text { and } \\
R & =.127
\end{aligned}
$$

then:

$$
\begin{aligned}
& T D=(48,655) /(1-.127)=55,733 * 55,700 \\
& P R=(55,733)(.127)=7,078 * 7,080
\end{aligned}
$$


rates reflect the percentage usage of secondary materials (including Industrial Waste-derived products) in the production of paper, steel cans, aluminum cans, and glass and as such are not the same as the recycling rates of secondary materials from residential and commercial discards. More importantly, the calculation of the utilization rates for these materials includes the use of secondary materials generated from manufacturing as we11 as those recovered from residential and commercial sources. Given that a reported 41 percent of all Industrial Haste in Japan is recycled and that about 87 percent of all wastes in Japan are Industrial Wastes ${ }^{39}$, it is reasonable to assume that a significant quantity of the secondary materials used are from manufacturers. Therefore, there is no inconsistency between the associations' reported utilization rates and the estimated 15- to 28 -percent recycling rate of residential and commercial discards.

As impressive as this estimated recycling rate range is, it is only about one-half to one-third the rate reported by Hershkowitz and Salerni in their 1987 treatise on garbage management in Japan. ${ }^{40}$ In their book, Hershkowitz and Salerni state:

The overall recycling rate in Japan is simply not known. However, based on estimates that in the U.S., paper, metal and glass alone can easily account for $45-60 \%$ of the waste stream, it is likely that in Japan, with all categories of waste included, the overall national figure for recycling is about $50 \%$. (page 40)

Aithough the 50-percent rate cited above became more definitive in later writings by these authors (e.g., they state that "In all, Japan recycles about 50 percent of the waste it generates. ${ }^{141}$ ), there does not seem to be any basis for their assertion that 50 percent of residential and commercial discards are recycled in Japan.

The cost of managing the 48.7 million tonnes of MSW treated by municipal governments in FY89 was approximately 1.26 trillion yen, or about $\$ 175$ per ton. Of this cost, 26 percent was for facility and vehicle capital costs, ${ }^{42}$ and the balance was for operation and maintenance (including

${ }^{39}$ Plastic Wastes (1991), p. 174.

${ }^{40}$ Hershkowitz, Allen and Salerni, Eugene, Garbage Management in Japan: Leading the Way (New York: INFORM, Inc., 1987).

${ }^{41}$ Hershkowitz, Allen and Salerni, Eugene, "The Recycling Yen", waste Alternatives, Vol. 19.

${ }^{42}$ The referenced data (Japanese Disposal of Waste - 1989) does not indicate whether the facility and vehicle capital costs represent expensed or capitalized values. 
collection and research). About 79 percent of the funds came from general revenues, 4 percent from the national and prefectual treasuries, 5 percent from charges and fees, 11 percent from bond funds, and the balance from other sources. Labor costs accounted for about 40 percent of the total costs and 53 percent of the operating and maintenance costs. ${ }^{43}$

The contribution from the national treasury represents about 15 percent of the facility costs. Since the national government currently provides a 25-percent subsidy for the construction of MSW treatment facilities, a contribution of 15 percent indicates that total facility costs include costs that are not subsidized by the national government. Such costs do not include amenities, such as pools, recreational halls, public baths, and sports complexes, which are built along with the treatment facilities as required by the agreements negotiated with the local communities.

${ }^{43}$ Japanese Disposal of Waste - 1989 (1991), pp. 42-43. 
REFERENCES

Clean Japan Center. Recyc]ing Guide for Beginners, 1992.

Fujiwara, Masahiro. Current Status of Waste Treatment in Japan. Water Supply and Environmental Sanitation Department, Ministry of Health and Welfare; Presented at joint meeting between the United States and Japan, October 1992. (English)

Fundamental Styles of Recycling Activity in Mequro Ward, study commission report, 1987. (Japanese)

Hershkowitz, Allen and Salerni, Eugene. Garbage Management in Japan: Leading the Way. New York: INFORM, Inc., 1987.

Hershkowitz, Allen and Salerni, Eugene. "Garbage Management in Japan: Leading the Way," Civil Enqineering, August 1988.

Hershkowitz, Allen and Salerni, Eugene. "The Recycling Yen", Waste Alternatives, Vol. 19.

Japan Institute of Infra-Structure. Guidelines for Construction of High Rate Composting Systems, January 1983. (English)

Japan Institute of Infra-Structure. Guidelines of Solid Waste Management, March 1982. (English) (Originally published by Ministry of Health and Welfare in 1 ate 1970s.)

Meguro Recycling Program Group. Basic Principles of Recycling Project in Meguro-ku, March 1989. (Japanese)

Ministry of Health and Welfare. Annual Report on Health and Welfare 1990 - 1991, January 1992. (English)

Ministry of Health and We]fare. Japanese Disposal of Waste [Nihon no Haikibutsu Shoril 1989. Water Supply and Environmental Sanitation Department, Office of Environmental Maintenance, December 1991. (Japanese)

Ministry of Health and Welfare. Solid Waste Management in Japan, 1990. (English)

Okayama Residential Waste Management Plan, March 1988. (Japanese)

Ostrand, Inc., LTD. Matsudo City, Basic Plan for General Waste (Waste Edition), [Ippan haikibutsu shori kikon keikaku, (gomi hen)]. Matsudo City Department of Sanitation, March 1988. (Japanese)

Ostrand, Inc., LTD. Matsudo City - Investigation of Weights of Household Waste: Report, [Matsudo-shi katei gomi keiryo chosa: hokokusho]. Matsudo City Department of Sanitation, March 1987. (Japanese) 
Ostrand, Inc., LTD. Tana District Investigation of Weights: Report, [Tana chiko keiryo chosa: hokokusho]. Tokyo Towns and Villages Autonomous Board of Investigations (foundation), May 1992. (Japanese)

Ostrand, Inc., LTD. Tana District Investigative Surveys on Household Waste: Report, [Tana chiku katei gomi anketo shose: kokokuso]. Tokyo Towns and Viliages Autonomous Board of Investigations (foundation), May 1992. (Japanese)

United States Environmental Protection Agency. Decision-Makers'. Guide to Solid Waste Management, March 1982 (EPA/530-SW-89-072).

United States Environmental Protection Agency. The Solid Waste Dilemma: An Agenda for Action. Final report of the Municipal Solid Waste Task Force, Office of Solid Waste, February 1989 (EPA/530-SW-89-019). 
4.

\section{CASE STUDIES}

\section{$4.1 \quad$ FUKUOKA CITY}

Fukuoka City, one of the 12 Designated Cities, had a 1991 population of 1.2 million persons, making it the largest city on Kyushu, the southernand western-most of the four main islands of Japan. Located on the northern coast of Kyushu, Fukuoka City is the center of trade and commerce on the island. With a land area of 336 square kilometers, its population density is approximately 3,500 persons per square kilometer $(9,190$ persons per square mile).

Fukuoka City is of interest because it commissioned the Seibu Incinerator Plant, a new waste-to-energy facility, in March 1992 and has embarked on a program of mechanical separation of recyclable materials from mixed MSW rather than source separation and hand sorting.

The following section describes Fukuoka City's integrated MSW management system, including MSW flow data. The Seibu Incinerator Plant is described in Section 4.1.2, with particular attention given to the approval process for this facility. The Eastern Crushing Disposal Center, Fukuoka's mixedwaste processing facility, is discussed in Section 4.1.3.

\subsubsection{Fukuoka's Municipal Solid Waste Management System}

As is typical of many cities in Japan, particularly large cities, Fukuoka City residents separate their MSW into only combustible and noncombustible fractions. Bulky wastes are also collected, separately. In FY91, just over 74 percent of the MSW collected from residences was separated as combustible waste, which includes kitchen waste, paper, paper diapers, fibers, wood, straw, some plastics, and leather. The balance was noncombustibie waste (which includes steel and aluminum cans, other metal discards, glass bottles and other breakables, some plastics, rubber, sand, and ashes) and bulky waste (e.g., furniture, appliances). Almost 78 percent of the MSW generated by both residential and commercial generators and received by the City was classified as combustible waste. The composition of the combustible and noncombustible waste fractions is provided in Table 4-1.

In FY91 Fukuoka City managed 713,107 tonnes of MSW. of this amount, 36,106 tonnes were imported from three neighboring municipalities: Kasuga, Hisayama, and Nakagawa, which have an aggregate population of 134,000. The FY91 annual per capita MSW generation rate for Fukuoka City, exclusive of these other communities, was 0.54 tonnes per person (i.e., about 3.3 pounds per person per day).

44"Japan Local Government Data Book 1991" (Council of Local Authorities for International Relations, March 1992), p. 240.

${ }^{45}$ Environmental Bureau, Fukuoka City, Survey of Operations (Planning Section, Department of Management, Environmental Bureau, July 1992), p. 23. 
TABLE $4-1$

FUKUOKA CITY MSW COMPOSITION: 1987 THROUGH 1991

\begin{tabular}{|c|c|c|c|c|c|c|c|c|c|c|}
\hline \multirow[t]{2}{*}{ COMPONENT } & \multicolumn{2}{|l|}{1987} & \multicolumn{2}{|l|}{1988} & \multicolumn{2}{|l|}{1989} & \multicolumn{2}{|l|}{1990} & \multicolumn{2}{|l|}{1991} \\
\hline & $\begin{array}{l}\% \text { Dry } \\
\text { Basis }\end{array}$ & $\begin{array}{l}\% \text { Wet } \\
\text { Basis }\end{array}$ & $\begin{array}{l}\% \text { Dry } \\
\text { Basis }\end{array}$ & $\begin{array}{l}\% \text { Wet } \\
\text { Basis }\end{array}$ & $\begin{array}{l}\% \text { Dry } \\
\text { Basis }\end{array}$ & $\begin{array}{l}\% \text { Wet } \\
\text { Basis }\end{array}$ & $\begin{array}{l}\% \text { Dry } \\
\text { Basis }\end{array}$ & $\begin{array}{l}\% \text { wet } \\
\text { Basis }\end{array}$ & $\begin{array}{l}\% \text { Dry } \\
\text { Basis }\end{array}$ & $\begin{array}{l}\% \text { Wet } \\
\text { Basis }\end{array}$ \\
\hline \multicolumn{11}{|l|}{ COMBUST IBLE WASTE } \\
\hline $\begin{array}{l}\text { Paper } \\
\text { Textiles } \\
\text { Grass \& Hood } \\
\text { Plastic, Leather, Paper }\end{array}$ & $\begin{array}{r}36.8 \\
4.0 \\
6.8\end{array}$ & $\begin{array}{r}19.3 \\
2.1 \\
3.6\end{array}$ & $\begin{array}{r}37.8 \\
3.5 \\
11.2\end{array}$ & $\begin{array}{r}20.9 \\
1.9 \\
6.2\end{array}$ & $\begin{array}{r}43.7 \\
3.6 \\
8.1\end{array}$ & $\begin{array}{r}24.5 \\
2.0 \\
4.6\end{array}$ & $\begin{array}{r}42.7 \\
4.3 \\
8.8\end{array}$ & $\begin{array}{r}25.4 \\
2.5 \\
5.3\end{array}$ & $\begin{array}{r}41.7 \\
4.2 \\
12.0\end{array}$ & $\begin{array}{r}24.1 \\
2.4 \\
7.0\end{array}$ \\
\hline $\begin{array}{l}\text { Diapers, etc. } \\
\text { Noncombustibles } \\
\text { Miscellaneous }\end{array}$ & $\begin{array}{l}15.3 \\
10.7 \\
26.4\end{array}$ & $\begin{array}{r}8.0 \\
5.6 \\
13.8\end{array}$ & $\begin{array}{l}15.7 \\
11.8 \\
20.0\end{array}$ & $\begin{array}{r}8.7 \\
6.6 \\
11.1\end{array}$ & $\begin{array}{r}17.1 \\
9.2 \\
18.3\end{array}$ & $\begin{array}{r}9.6 \\
5.1 \\
10.3\end{array}$ & $\begin{array}{r}15.4 \\
9.6 \\
19.2\end{array}$ & $\begin{array}{r}9.2 \\
5.8 \\
11.4\end{array}$ & $\begin{array}{r}15.4 \\
9.2 \\
17.5\end{array}$ & $\begin{array}{r}8.9 \\
5.4 \\
10.1\end{array}$ \\
\hline Moisture & & 47.6 & & 44.6 & & 43.9 & & 40.4 & & 42.1 \\
\hline $\begin{aligned} & \text { Heating value }(\mathrm{kcal} / \mathrm{kg}) \\
&(\mathrm{Btu} / \mathrm{lb})\end{aligned}$ & & & & & & & & & 2, & \\
\hline \multicolumn{11}{|l|}{ NONCOMBUSTIBLE WASTE } \\
\hline $\begin{array}{l}\text { Earth \& Sand, Rubbie } \\
\text { Metals } \\
\text { Ash } \\
\text { Glass } \\
\text { Kitchen Waste } \\
\text { Plastic \& Rubber } \\
\text { Combustibles }\end{array}$ & $\begin{array}{r}6.8 \\
22.6 \\
1.7 \\
21.2 \\
1.4 \\
13.5 \\
32.8\end{array}$ & & $\begin{array}{r}8.3 \\
22.4 \\
1.5 \\
23.2 \\
1.1 \\
14.1 \\
29.4\end{array}$ & & $\begin{array}{r}7.1 \\
22.1 \\
1.0 \\
21.6 \\
1.6 \\
12.7 \\
33.9\end{array}$ & & $\begin{array}{r}6.2 \\
26.9 \\
1.4 \\
20.0 \\
1.2 \\
12.8 \\
31.5\end{array}$ & & $\begin{array}{r}9.9 \\
24.6 \\
0.8 \\
17.8 \\
1.3 \\
13.5 \\
32.1\end{array}$ & \\
\hline
\end{tabular}

Source: $\quad$ Fukuoka City, "Summary of Operations," Fiscal Year 1992. 
Fukuoka City's integrated MSW management system consists of three wasteto-energy facilities; three bulky-waste shredding facilities, located at each of the three waste-to-energy facility sites; a mixed-waste shredding and materials recovery facility; and two landfills.

The three waste-to-energy facilities are: (1) the Southern Refuse Incineration Plant; the Seibu (Western) Incineration Plant; and the Eastern Refuse Incineration Plant. The Southern Refuse Incineration Plant is located in Kasuga. This 600-tonne-per-day (TPD) (24-hour) facility was commissioned in March 1981. The Southern facility includes two 10-tonneper-hour bulky waste shredders.

The Seibu Incineration Plant, or "Western Plant," was completed in March 1992. The commissioning of the Seibu facility allowed the city to demolish an old incinerator that was located on an adjacent site. Another 10-tonne-per-hour bulky waste shredder is located at this facility. The Seibu Incineration Plant is discussed in more detail in Section 4.1.2. The Seibu (Imazu) Reclamation Site, i.e., the Western Landfill, opened in 1974 with an expected useful 1 ife of 21 years. A sports park is planned for construction on portions of this 1 andfill that have been closed. ${ }^{6}$

The complex of facilities in the eastern section of the city is a truly integrated MSW management system in and of itself. Originally, two 300 TPD waste-to-energy units, which were completed in 0ctober 1976, were built at the Eastern Refuse Incineration Plant. The ash from this facility and noncombustible waste from the 10 -tonne-per-hour bulky waste shredder were disposed of in the Tohbu (Busetsugaura) Reclamation site (i.e., landfi11) until 1987 when this landfill closed. An additional 200TPD waste-to-energy unit, completed in July 1990, was built adjacent to the original facility. The new facility is a revolving fluidized-bed unit designed to combust the high-heat-content combustible materials recovered from the adjacent 250-TPD (5 hours) Eastern Crushing Disposal Facility (see Section 4.1.3 for more details). ${ }^{47}$ Shredded combustible refuse that has been separated in the Eastern Crushing Disposal Facility is transported to the new waste-to-energy facility by conveyor. Steam produced at the new waste-to-energy unit is used for the explosionprotection system at the Eastern Crushing Disposal Facility. The wasteto-energy facility also provides electricity to the Eastern Crushing Disposal Facility.

The new waste-to-energy unit's air pollution control equipment includes an electrostatic precipitator (ESP) designed for $0.03 \mathrm{~g} / \mathrm{Nm}^{3}$. A calcium hydroxide spray injected prior to the ESP is used to control acid gases.

\footnotetext{
${ }^{46}$ Fukuoka City, "Tohbu (Fushitani) Reclamation Site" (Environmental Bureau, undated), pp. 9-10.

${ }^{47}$ Although there have been some mechanical problems with the fluidized-bed unit, city officials and the plant operator feel that fluidized-bed technology is attractive for small-scale systems because of the ease of starting up and shutting down the unit.
} 
The waste from the new combustion unit is treated at the adjacent water treatment equipment, constructed in conjunction with the original Eastern Refuse Incineration Plant facjlity. The fly ash collected by the ESP is hardened with cement prior to disposal in the Tohbu (Fushitani) Reclamation Site landfill. ${ }^{48}$ This landfill opened in 1988 and has a 15year life expectancy. Combustion ash from the Eastern Refuse Incineration Plant facilities and noncombustibles from the Eastern Crushing Disposal Facility, as well as Industrial Wastes, are landfilled at this site. ${ }^{49}$

A flow diagram showing the sources of Fukuoka City's MSW and its disposition throughout the City's integrated system is provided in Figure 4-1. of the 713,107 tonnes treated by the City in FY91, approximately 82 percent was combusted, which is well above the national average of 74 percent. About 30 percent was combusted at each of the Western, Southern, and original Eastern plants, with the remaining 10 percent having been combusted in the new waste-to-energy unit at the Eastern site.

About 51,000 tonnes or, 7.2 percent, of the MSW was processed through the bulky shredders at the Eastern Crushing Disposal Center. Of this amount, almost 60 percent was recovered as combustible material, while almost 18 percent was recovered as saleable ferrous and aluminum metals. This represents a municipal recycling recovery rate from Fukuoka's City-treated MSW of only 1.3 percent, which is well below the national average of 3.1 percent.

About 110,000 tonnes or, 15 percent, of the MSW was sent directly to the landfills. Inciuding the 103,000 tonnes of ash generated at the waste-toenergy facilities and the 12,400 tonnes of residue from the Eastern Crushing Disposal Facility, about 32 percent, by weight, of the MSW was landfilled. Since almost half of the material landfilled consisted of ash, the volume reduction was significantly greater than the weight reduction of the MSW.

\subsubsection{The Seibu ("Western") Incineration Plant}

Fukuoka City relies very heavily on combustion to manage its MSW. The Seibu waste-to-energy plant is one of the newest facilities in not only Fukuoka City, but also in al] of Japan. This section provides a brief description of this facility, which was designed and constructed by Takuma Co. Ltd., Yamashita Design Co., Ltd., and Hazama, Sato, Kakudo, Ooki, Kakihara Joint Enterprises, and which is representative of the newer facilities now being built in Japan.

Construction of the Seibu Incineration Plant began in September 1988 and was completed in March 1992. Adjacent to the waste-to-energy facility is

\footnotetext{
${ }^{48}$ Fukuoka City, "Eastern Refuse Incineration Plant, Second Plant" (July 1990), p. 14 .

${ }^{49}$ Tohbu (Fushitani) Reclamation Site," p.2 .
} 
FIGURE 4-1: FUKUOKA CITY MSW FLOW DIAGRAM: FISCAL YEAR 1991 (tonnes)

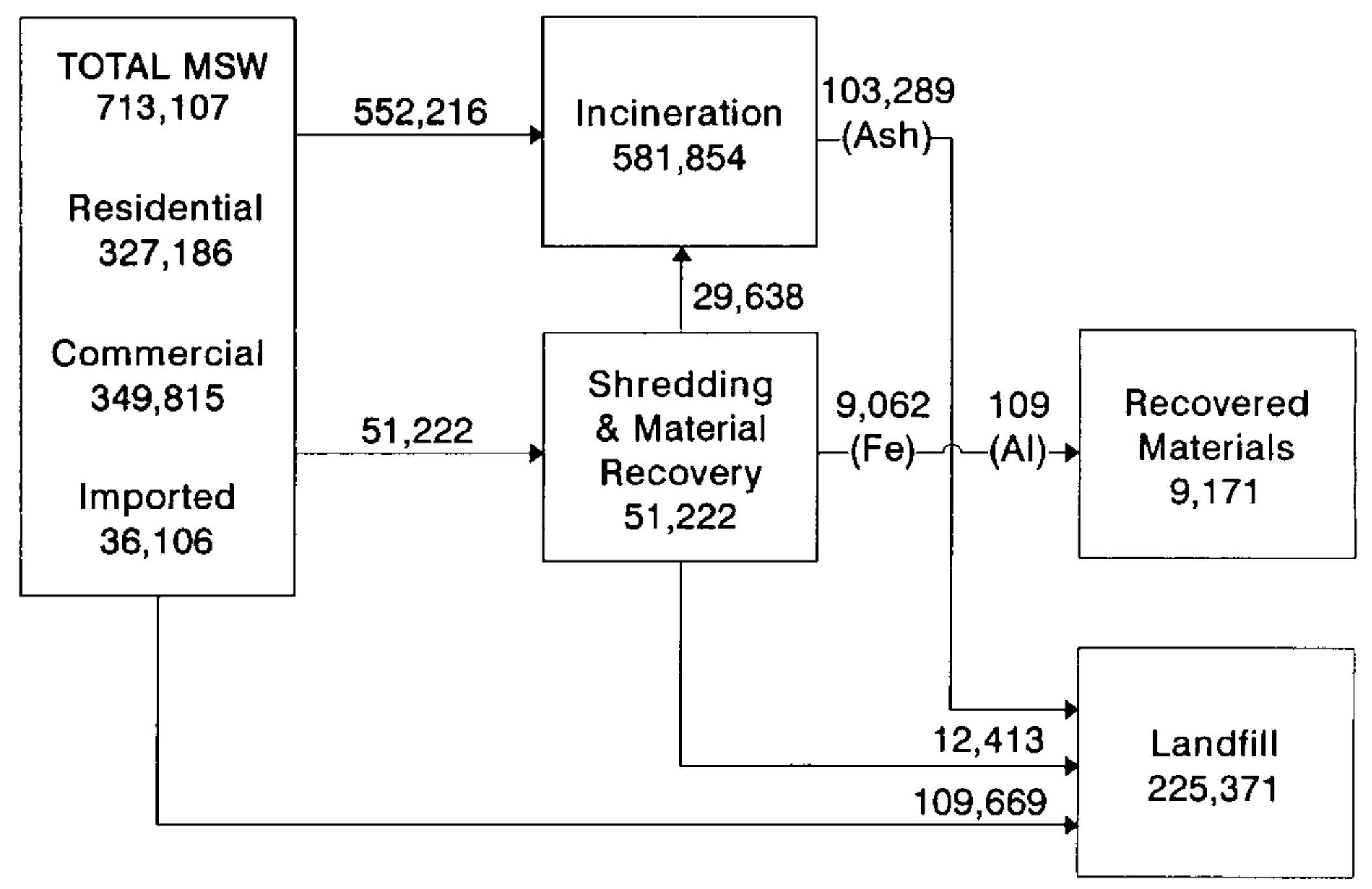


a shredding and sorting facility for noncombustible MSW. The waste-toenergy facility is designed to combust the combustible fraction of the MSW recovered from the shredding and sorting facility as well as the sourceseparated combustible MSW collected from residences. This means it has been designed for higher heat-content waste that includes many of the plastics, rubber, and other materials that cannot be combusted in the older Japanese incinerators.

Unlike most waste-to-energy facilities in Japan, the Seibu facility is a co-generation facility, and sells electricity to the local utility company as we]l as providing steam and electricity to the Fukujuen Senior Citizens' Welfare Center and community swimming pool, which are adjacent to the facility. Japan does not have a law similar to the U.S. Public Utility Regulatory Policies Act (PURPA), which requires local utilities to interconnect with waste-to-energy facilities and purchase power from them at the utilities' avoided cost. Therefore, use of energy produced by Japanese waste-to-energy facilities is usually limited to in-plant usage and provision of steam and sometimes electricity to community centers, greenhouses, pools, baths, and the like.

The Seibu waste-to-energy facility has three 250-TPD (24-hour) units that utilize the Takuma pusher-grate system and was built for a reported 24.4 billion yen (approximately $\$ 180$ million). Of this amount, approximately 56 percent was for mechanical equipment; 27 percent for civil and building work (including a greenhouse near the entrance of the facility); 6 percent for an adjacent senior citizens' recreational hall; 5 percent for site preparation; 4 percent for site purchase; 1 percent for demolition of the old plant; and less than I percent was for administrative costs. The waste is combusted at temperatures ranging from 850 to $950^{\circ} \mathrm{C}$ (approximately 1,550 to $1750^{\circ} \mathrm{F}$ ). Combustion is controlled, and air emissions are monitored by a centralized computer system to improve the combustion efficiency and to reduce specified emissions. The pollution control chain consists of, in the following order, a denitrator for injecting urea into the furnace for the control of nitrogen oxides; an ESP for the control of particulate matter; and a wet scrubber for the control of acid gasses. Wastewater generated by the plant is treated on-site to remove heavy metals and other harmful substances. The treated water is either reused within the facility or evaporated to recover saleable industrial salts.

Planning for this facility began in 1981, just over 10 years prior to its commissioning. In Japan, a 10 -year planning horizon is not uncommon. 50 Typical development steps include site acquisition, site assessment, environmental impact assessments, negotiation of local community agreements, holding of public meetings, and application for national government subsidies. Many of these steps are conducted simultaneously.

${ }^{50} \mathrm{~A}$ facility in Omiya city that is scheduled to be commissioned in early 1993 was also developed over a 10-year period. Its development schedule was similar to the development of the Seibu Plant (discussions between $A l$ an $S$. Cohen and Omiya City Officials and plant personnel, October 21, 1992). 
A site study for the Seibu Incineration Plant began in 1981. Fukuoka City needed to purchase the proposed site from the national government. As such, the acquisition of the site was relatively easy. Acquiring private property otherwise can be quite time-consuming because of the Japanese reluctance or inability to exercise eminent domain powers.

The Environmental Section of Fukuoka City began a one-year environmental monitoring program in October 1982. The preparation of an environmental impact assessment began in 1983 and included air and water qual ity impact analysis; noise, vibration, and odor impact analysis; and a cultural asset evaluation. Although an environmental impact assessment is not required by law, the MHW requires such an assessment for obtaining a construction subsidy from the national government. Furthermore, the environmental impact assessment was used to gain pubTic support for the project. Although the envirommental impact assessment process did not involve public hearings, the public had access to the monitoring results and the environmental impact assessment.

The project was first officially explained to the public in 1985 . Meetings were held with citizens representing neighborhoods near the site. These representatives were interested citizens, not elected officials. The representatives, in turn, explained the project to the households within their neighborhoods. An agreement between the City and the loca] citizens established environmental controls, which were more stringent than the federal requirements, to be employed at the Seibu Plant. Typically, the citizens' groups, usually without the help of consultants or paid professionals, determine the types of environmental controls being employed elsewhere and request the same for their facilities. Generally, the most stringent control technologies employed elsewhere in Japan were employed in Fukuoka City at the Seibu PIant. The citizens' groups also negotiated a greenhouse, a senior citizens' recreational hall, a swimming pool, and other community amenities.

Because these sorts of amenities are common in Japan, the requirements of the citizens' groups are planned for by the city officials. In some instances, local public works projects are delayed to provide room for negotiations with the local community for the construction of other, less attractive projects such as a waste-to-energy facility. ${ }^{51}$ The negotiations with the citizens in Fukuoka City were relatively easy because the new Seibu Plant facility was replacing an old incinerator.

The application for the national subsidy was submitted in 1986, and construction began in 1987 .

${ }^{51}$ Such a situation occurred in Omiya City, whereby the city agreed to make certain road improvements as part of the local agreement to site the new waste-to-energy facility. 


\subsubsection{The Eastern Crushing Disposal Facility}

Construction of the Eastern Crushing Disposal Facility recycling center began in October 1984 and was completed in September 1986 by Takuma Co., Ltd., Kakihara-gumi Co., Ltd., Nishiteletsu Densetsu Industrial Co., Ltd., and Token Industrial Co., Ltd. for a reported 2 billion yen (approximately $\$ 15$ million), exclusive of site acquisition costs. 52 The Eastern Crushing Disposal Facility was designed to recover combustibles and recyclable materials (i.e., ferrous metal and aluminum) from noncombustible and bulky waste. The facility has two 25-tonne-per-hour trains, for a daily capacity of 250 tonnes ( 5 hours of operation per day).

A flow diagram of a single train of the Eastern Crushing Disposal Facility is illusrated in Figure 4-2. The noncombustible fraction of the MSW and the bulky waste are first shredded, using transverse-rotary horizontal hammer mills. The shredded material then passes under a hanging-belt, 25tonne-per-hour magnet to separate the MSW into ferrous and nonferrous fractions. The ferrous fraction next passes by a 6-tonne-per-hour drum magnet which separates loose tramp material from the ferrous fraction. The ferrous material is conveyed to the ferrous storage area. The tramp is combined with the combustible fraction.

A 20-tonne-per-hour vibrating screen is used to separate the nonferrous fraction into combustible and noncombustible fractions. Nonferrous metal, principally aluminum, is recovered from a portion of the noncombustible fraction using a set of two linear motors. The first is rated at 4 tonnes per hour, while the second is rated at 0.2 tonnes per hour. The recovered aluminum is then conveyed to the aluminum storage area. Throughout the process, combustible material is recovered and commingled with the combustible fraction. The combustible fraction is conveyed to and stored at the Eastern Refuse Incineration Plant's storage pit.

Bag filters are used to control dust emissions from the facility. The facility was designed to minimize vibration and noise. Steam from the Eastern Refuse Incineration Plant is blown into the shredder to reduce the oxygen concentration and thus suppress explosions within the shredder.

From 1986 through $1989,50.8$ percent of the MSW that had been sorted and collected as "noncombustible and bulky waste" was, upon processing at the Eastern Crushing Disposal Facility, separated into the combustible fraction (that is, the noncombustible sorts were, as is typical, impure and contained combustibles; also, upon processing, combustible elements of the bulky waste were separated out); 16.5 percent was separated into the ferrous metal fraction; and 0.2 percent was separated into the non-ferrous

${ }^{52}$ Fukuoka City, "Eastern Crushing Disposal Facility" (Environmental Bureau, September 1986), p. 2 .

${ }^{53}$ The Tezuka Press lists over 250 similar installations throughout Japan. See "Waste Can Become a Treasure." 
FIGURE 4-2

EASTERN CRUSHING DISPOSAL FACILITY: FLOW DIAGRAM

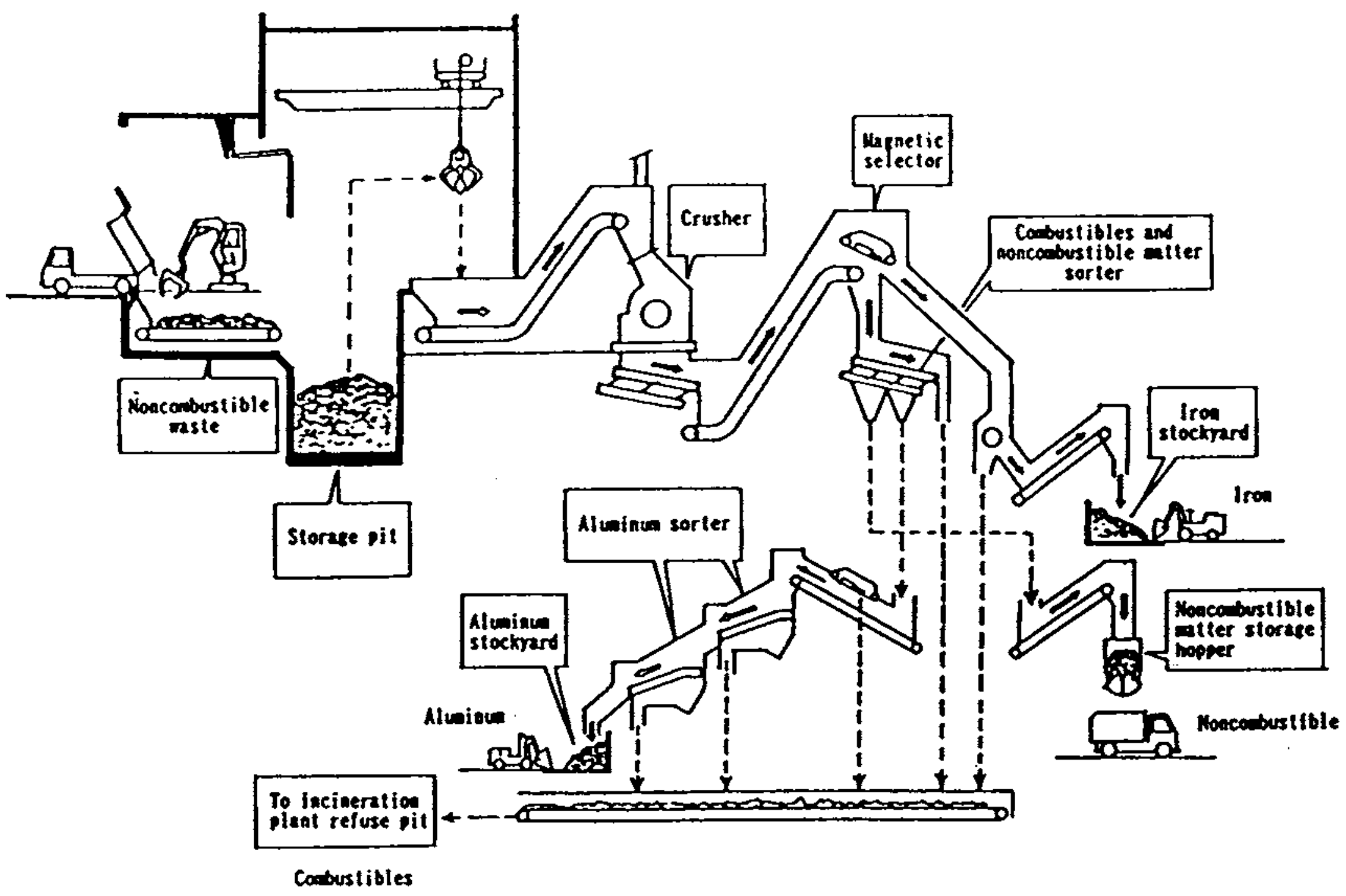

Source: "Recycling Plants in Japan and the Operational Sumiary," K. Nakazato, S. Inoue, and T. Hamano; May 1992. 
fraction..$^{54}$ The balance was noncombustible residue that was sent to the landfill. The composition and purjty of the recovered material are shown in Tables 4-2 and 4-3. As can be seen, the Eastern Crushing Disposal Facility is able to recover highly concentrated ferrous ( 96.9 percent) and nonferrous (96.2 percent) products. Although the composition of the combustible fraction included only 65 percent combustible material, more than 90 percent of the combustibles in the material processed was captured in the combustible fraction. Since this processed material was originally source-separated as noncombustible waste or bulky waste, the Eastern Crushing Disposal Facility recycling center has been quite successful in diverting such materials from the landfills. Specifically, over the three-year period of 1986 through 1989, Fukuoka City was able to divert from the landfills about 48 percent, by weight, of the materials processed at the Eastern Crushing Disposal Facility, and 86 percent, by volume (taking into consideration the volume reduction effects of the Eastern Incineration Plant).

\subsubsection{Summary and Conclusions}

Fukuoka City is illustrative of the approximately 80 percent of municipalities in Japan that do not collect source-separated recyclables. Many of these communities rely on mechanical recovery of recyclable materials and combustible MSW through systems similar to the one employed in Fukuoka City.

These communities rely heavily on combustion for volume reduction and sanitization of the MSW. Mixed-waste processing can further reduce the volume of material going to landfills through the recovery and recycling of metals and the recovery and combustion of combustible material that was improperly sorted by the waste generators.

Private recycling occurs in Fukuoka City, however, no statistics are available to estimate the effectiveness of such activities.

\section{$4.2 \quad$ MATSUDO CITY}

Incorporated in 1943, Matsudo City is located in northwest Chiba Prefecture, about 20 kilometers miles northeast of Tokyo. The city had an FY90 population of about 450,000 , which represents a 6.7 -percent increase since 1985. Its population density is about 7,300 persons per

${ }^{54} \mathrm{~N}$. Nakazuto, S. Inoue, and T. Hamano, "Recycling Plants in Japan and the Operational Summary" (prepared for the 15th National Waste Processing Conference and Exhibit, Detroit, Michigan, May 17-20, 1992), p. 10.

55"Recycling Plants in Japan and the Operational Summary," p. 10. 
TABLE 4-2

EASTERN CRUSHING DISPOSAL FACILITY COMPOSITION OF RECOVERED MATERIALS (percent)

\begin{tabular}{|c|c|c|c|c|}
\hline COMPONENT & $\begin{array}{l}\text { RECOVERED } \\
\text { FERROUS }\end{array}$ & $\begin{array}{l}\text { RECOVERED } \\
\text { NONFERROUS }\end{array}$ & $\begin{array}{l}\text { RECOVERD } \\
\text { COMBUSTIBLES }\end{array}$ & $\begin{array}{l}\text { NONCOMBUSTIBLE } \\
\text { RESIDUE }\end{array}$ \\
\hline $\begin{array}{l}\text { Paper } \\
\text { Textiles } \\
\text { Grass \& Wood } \\
\text { Plastic } \\
\text { Rubber \& Leather } \\
\text { Cotton Batting } \\
\text { Kitchen Waste } \\
\text { Ferrous } \\
\text { Nonferrous: }\end{array}$ & $\begin{array}{r}0.1 \\
1.1 \\
0.1 \\
0.6 \\
0.1 \\
0.2 \\
0.0 \\
96.4\end{array}$ & $\begin{array}{l}0.1 \\
0.0 \\
0.4 \\
0.9 \\
0.6 \\
0.0 \\
0.0 \\
0.3\end{array}$ & $\begin{array}{r}26.9 \\
3.9 \\
14.8 \\
11.3 \\
0.4 \\
7.5 \\
0.0 \\
3.0\end{array}$ & $\begin{array}{r}10.5 \\
2.4 \\
12.4 \\
9.6 \\
0.4 \\
3.6 \\
0.1 \\
2.2\end{array}$ \\
\hline $\begin{array}{l}\text { Copper, Zinc, } \\
\text { etc. } \\
\text { Aluminum }\end{array}$ & 0.5 & 7.7 & 0.2 & 0.5 \\
\hline $\begin{array}{l}\text { Cans } \\
\text { Impurities } \\
\text { Others }\end{array}$ & $\begin{array}{l}0.0 \\
0.5 \\
0.2\end{array}$ & $\begin{array}{l}52.1 \\
11.8 \\
24.6\end{array}$ & $\begin{array}{l}0.4 \\
0.2 \\
0.8\end{array}$ & $\begin{array}{l}0.0 \\
0.0 \\
0.6\end{array}$ \\
\hline $\begin{array}{l}\text { Earth \& Sand, } \\
\text { Rubble } \\
\text { G]ass } \\
\text { Others (<5 mm) }\end{array}$ & $\begin{array}{l}0.0 \\
0.0 \\
0.2 \\
\end{array}$ & $\begin{array}{l}0.0 \\
0.0 \\
1.5 \\
\end{array}$ & $\begin{array}{r}0.3 \\
4.5 \\
25.8 \\
\end{array}$ & $\begin{array}{r}3.3 \\
12.2 \\
42.2 \\
\end{array}$ \\
\hline TOTAL & 100 & 100 & 100 & 100 \\
\hline
\end{tabular}

Source: Nakazato, K., et al, "Recycling Plants in Japan and the Operational Summary," May 1992. 
TABLE 4-3

EASTERN CRUSHING DISPOSAL FACILITY

PURITY OF RECOVERED MATERIALS

(percent)

\begin{tabular}{llllr}
\hline COMPONENT & $\begin{array}{l}\text { RECOVERED } \\
\text { FERROUS }\end{array}$ & $\begin{array}{l}\text { RECOVERED } \\
\text { NONFERROUS }\end{array}$ & $\begin{array}{l}\text { RECOVERD } \\
\text { COMBUSTIBLES }\end{array}$ & $\begin{array}{l}\text { NONCOMBUSTIBLE } \\
\text { RESIDUE }\end{array}$ \\
\hline Ferrous & 96.4 & 0.3 & 3.0 & 2.2 \\
Nonferrous & 1.2 & 96.2 & 1.6 & 1.1 \\
Combustible & 2.2 & 2.0 & 64.8 & 39.0 \\
Noncombustible & 0.2 & 1.5 & 30.6 & 57.7 \\
\hline
\end{tabular}

Source: Nakazato, K., et al, "Recycling Plants in Japan and the Operational Summary," May 1992. 
kilometer $\left(19,000\right.$ persons per square mile). ${ }^{56}$ Matsudo City has instituted a source-separation recycling program and actively supports private-sector recycling through subsidy payments to group recyclers and price-support payments to recycling dealers.

Matsudo's MSW management program, including the quantity of MSW generated and methods of treatment employed by the city, is described in Section 4.2.1. Section 4.2.2 describes the City's recycling program, and Section 4.2.3 describes private-sector recycling. Also presented in Section 4.2.3 are the results of a detailed study performed in 1986 by 0strand, Inc., LTD., a Japanese consulting firm, to estimate Matsudo City's total discards and the methods employed by residences and businesses to dispose of these discards. The municipal data and 0strand study data have been combined to obtain estimates of generation, recycling rates, and compositions of gross discards, which are presented in Section 4.2.4.

\subsubsection{Municipal Solid Waste Management System}

Matsudo City requires its residents to separate their MSW into five categories: combustible waste, noncombustible waste, recyclable materials, bulky waste, and Household Hazardous Waste. Combustible waste includes food waste, yard waste, paper, chopsticks, paper diapers, and cooking oil. Noncombustible waste includes some plastic and rubber products (e.g., vinyl, polystyrene, nylon), pottery, shells, leather, and relatively small tatami mats and rugs. Recyclables include newspapers, magazines, clothes, glass bottles, steel and aluminum cans, bicycles, and appliances (including television sets, washing machines, and refrigerators). Household Hazardous Wastes are those that contain mercury, such as dry cell batteries, thermometers, and fluorescent 1 ights.

The City does not provide door-to-door collection of separated residential MSW. Rather, MSW is deposited by residents at about 7,100 stations located throughout the city. This represents about one station per 20 households. The various classifications of waste are collected on different days. Combustible waste is collected three times a week, noncombustibles twice a week, and recyclables and household hazardous wastes once a week. The household hazardous wastes are placed in specially labeled plastic bags. Bulky waste can be delivered to municipal treatment facilities directly or be picked up by the City upon request. There was a total of 294 collection days during FY90.

During FY90, Matsudo City treated 142,231 tonnes of MSW. Figure 4-3 is a mass flow diagram of the City's MSW stream, illustrating the City's methods of treatment.

Matsudo City's MSW-processing system consists of two waste-to-energy facilities, two noncombustible- and bulky-waste shredding facilities, and

${ }^{56}$ Council of Local Authorities for International Relations, Japan Local Government Data Book 1991 (March 1992), p. 58. 
FIGURE 4-3: MATSUDO CITY MSW FLOW DIAGRAM: FISCAL YEAR 1990 (tonnes)

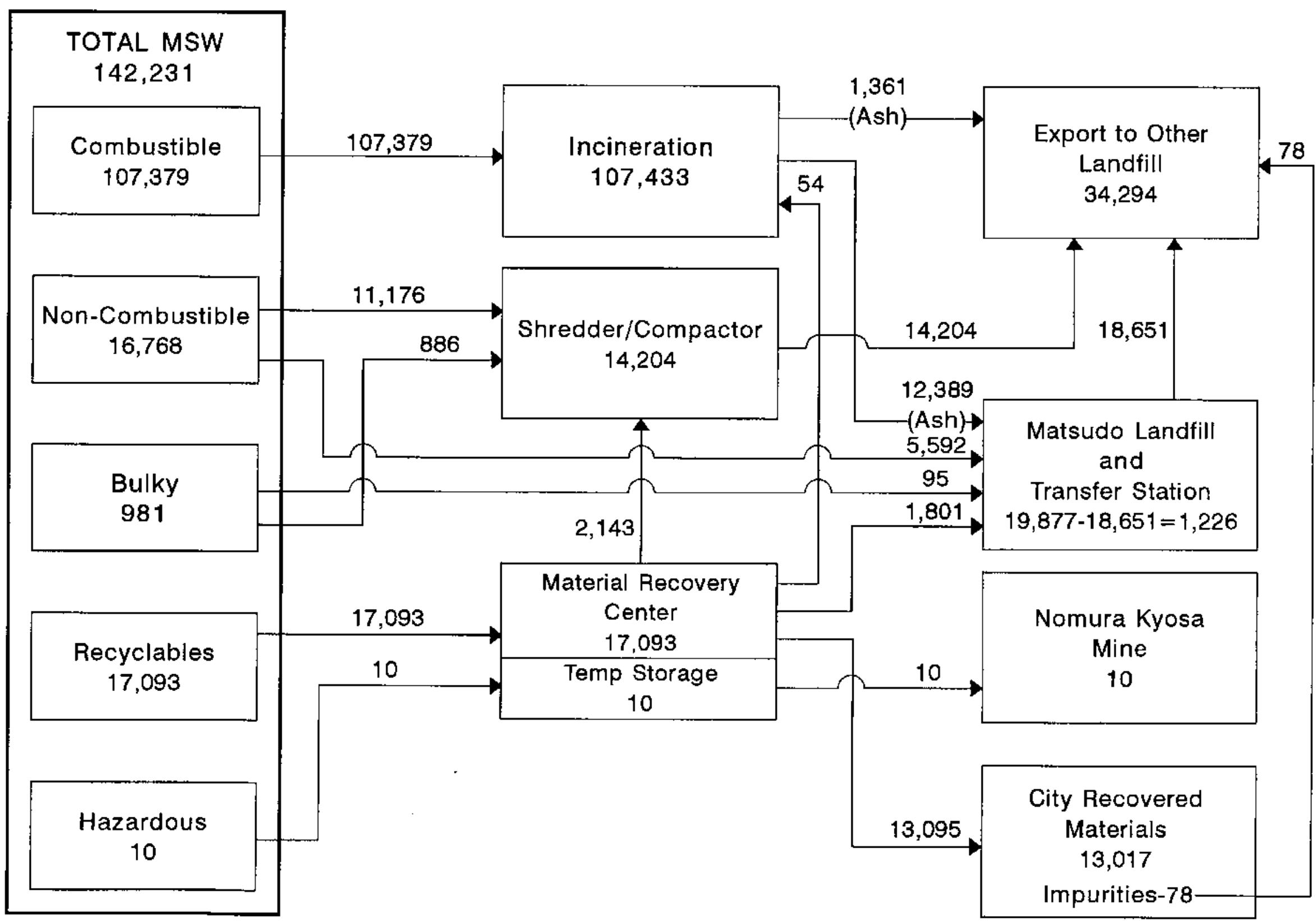

SOURCE: "Survey of Cleansing Operations (Sanitation)," Matsudo City, 1991. 
a materials recovery facility (MRF). The household hazardous wastes are temporarily stored at the MRF and eventually shipped to the Nomuka Kyosan mine in Hokkaido, where they are stored and treated.

Figure 4-4 depicts the percentages of combustible waste, noncombustible waste, recyclables, and "other" wastes that compose the City's collected MSW stream. The combustible waste fraction, approximately 76 percent of the MSW treated by Matsudo City, was combusted in the two waste-to-energy facilities. Each facility processed approximately equal quantities of combustible waste during FY90. Both residential and commercial combustible MSW were processed at the Rakuwa Clean Center, a waste-toenergy facility that began operations in November 1966 with the completion of a single unit, rated at 75 tonnes per 8 hours. A second unit, with a rated capacity of 200 TPD (24 hours), was added to the Rakuwa Clean Center in September 1976. Excess energy generated from the Rakuwa Clean Center is used in an adjacent park for heating public baths.

The other waste-to-energy facility, completed in November 1980, is sited along with a 20-tonne-per-hour shredding facility; together, these are referred to as Clean Center No. 2. Only residential combustible MSW is treated at this single-unit, 300-TPD (24 hours) facility. The excess energy produced at Clean Center No. 2 is used to heat a center for elderly people and a hot water swimming pool.

The City's MRF, referred to as the Resource Recycling Center, was completed in March 1981 and has a rated capacity of 10 tonnes per hour. It consists of a shredder, magnets, hand-sorting stations for reusable glass bottles and color-sorted cullet, and compactors for both paper and metals (ferrous and aluminum). Textiles primarily old clothing and bedding) are hand-sorted to separate reusable items. Motors and compressors of large appliances such as washing machines and refrigerators are removed prior to shredding. The ferrous metal from these appliances is magnetically recovered, Bicycles are also shredded to recover metals.

In Fy90, 17,093 tonnes of recyclable material (exclusive of materials from City-supported group recycling activities) were delivered to the Resource Recycling Center. of that amount, 13,017 tonnes (76.2 percent), were recovered for sale or reuse; 54 tonnes (0.3 percent) were combusted; and 4,022 tonnes (23.5 percent) of the material collected as recyclables became residue and were eventually landfilled.

Noncombustible and bulky wastes were either sent directly to the 7 andfill or shredded at the City's second shredding and compacting facility, which is located near the Resource Recycling Center. The compacted waste was then transported to a 1 andfill located outside of Matsudo City. Including 13,750 tonnes of combustion ash, a total of 34,294 tonnes of waste was landfilled in FY90. This is 24 percent, by weight, of the MSW treated by the city.

Although 28 percent of the MSW was generated by commercial sources, about 34 percent of the total combustible fraction was generated by commercial sources. This reflects the relatively large increase in office waste 


\section{FIGURE 4-4: MATSUDO CITY: MUNICIPAL SOLID WASTE COLLECTIONS (percent by weight, as collected)}

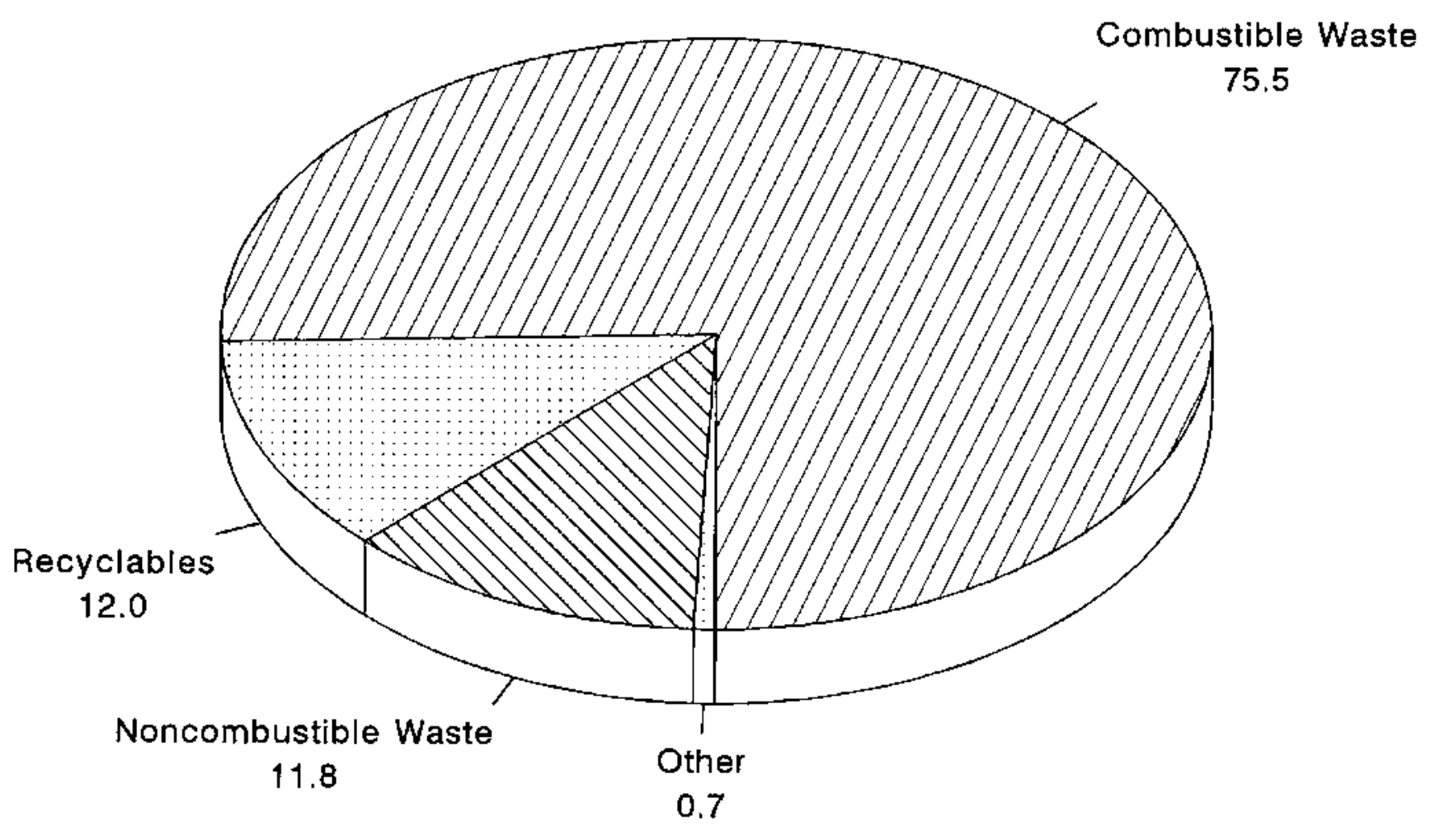


generation in Japan from 1986 to FY90. On the other hand, about 6 percent of the recyclable MSW was generated by the commercial sector. As will be seen in the following section, this is due in part to a relatively high degree of private recycling within the commercial sector.

\subsubsection{City Recycling Program and City-Supported Group Recycling}

Matsudo City has one of the more mature and successful municipal recycling programs in Japan. It consists of once-a-week collection, at approximately 7,100 stations, of recyclable materials; operation of the Resource Recycling Center MRF; shredding of noncombustible and bulky waste and magnetic recovery of ferrous metals; support for over 270 volunteer recycling groups; and material price supports for recycling dealers. Exclusive of the group recycling activities, in FY90 the City recovered 13,017 tonnes of recyclable MSW, or 9.2 percent of total MSW, which is well above the national average municipal recycling rate of 3.1 percent. An additional 2,334 tonnes of discards were recovered through citysponsored group recycling. Combined, these activities resulted in 10.6 percent of the sum of the MSW treated by the city and the discards collected through city-sponsored group recycling being recovered as saleable materials.

Table 4-4 shows the quantity and percentage composition of recyclable materials recovered in FY90. About 92 percent, by weight, of the materials recovered were newspapers/magazines, glass bottles, and metals. In FY90, Matsudo City received an average of about 6 yen per kilogram for the material it recovered from the MSW (or about $\$ 41 /$ ton). The city received about 2 yen per kilogram for paper $(\$ 15 /$ ton $)$; 11 yen per kilogram for metals (\$74/ton); and 5 yen per kilogram for textiles ( $\$ 34 /$ ton). 5

Group recycling has traditionally been a private-sector activity in Japan. Matsudo City officials realized that these volunteer groups provided a valuable public service by diverting discarded materials from the waste stream. For this reason, the City provides advisory services, including publication of materials to help start-up organizations, to help establish new groups within the city. The city pays recycling groups who meet certain standards, such as those regarding size and frequency of collection, on average about three yen for every kilogram of material collected. In FY90 this resulted in a subsidy of about 7 million yen (about $\$ 51,000)$.

Thirty-six large recycling groups were registered with the City in 1990 . In 1991 the city allowed smaller groups to qualify for the subsidy program, and in FY9l about 270 groups participated in the program. As a result of expanding the program, the quantity of recyclable material collected by the registered recycling groups increased from 2,300 tonnes in FY90 to 5,400 tonnes in FY91. Even with this expanded program there are still some recycling groups that are not part of the City program.

${ }^{57}$ Matsudo City Department of Sanitation, Matsudo City-Survey of Cleansing Operations, Fiscal Year 1991, pp. 49-50. 
TABLE 4-4

MATSUDO CITY: RECOVERED MATERIALS SOLD

(FISCAL YEAR 1990)

\begin{tabular}{lll}
\hline COMMODITY & QUANTITY & \\
\hline & Tonnes & $\%$ \\
\hline
\end{tabular}

CITY-RECOVERED MATERIAL

$\begin{array}{lrr}\text { Paper } & 3,172 & 24.4 \\ \text { Metals } & 4,126 & 31.7 \\ \text { Bottles and Glass } & 4,612 & 35.4 \\ \text { Textiles } & 546 & 4.2 \\ \text { Non-Value Material } & 558 & 4.3 \\ \text { Total } & 13,017 & 100.0\end{array}$

CITY-SPONSORED GROUP RECYCLING

$\begin{array}{lrr}\text { Paper } & 1,164 & 49.9 \\ \text { Metals } & 496 & 21.3 \\ \text { Bottles and Glass } & 520 & 22.3 \\ \text { Textiles } & 154 & 6.6 \\ \text { Non-Value Material } & 0 & 0.0 \\ \text { Total } & 2,334 & 100.0\end{array}$

TOTAL RECYCLED MATERIALS

$\begin{array}{lrr}\text { Paper } & 4,338 & 28.3 \\ \text { Metals } & 4,623 & 30.1 \\ \text { Bottles and Glass } & 5,132 & 33.4 \\ \text { Textiles } & 700 & 4.6 \\ \text { Non-Value Material } & \mathbf{5 5 8} & 3.6 \\ \text { Total } & 15,351 & 100.0\end{array}$

Source: Matsudo City "Summary of Cleaning Operations," Department of Sanitation, Fiscal Year 1991, p. 47. 
Another important component of the City's recycling program is its support of private recycling dealers. Traditionally, these dealers collected used goods, paid individuals or groups for the material they collected, and made a profit from the resale of these materials. However, as market values decreased for many of the materials, the profitability of collecting these materials decreased; as a result, more of this material found its way into the MSW stream.

Recognizing the value to the City of diverting these materials, Matsudo city has established a price-support mechanism to maintain the profitability of diverting certain materials during weak market conditions. For example, in 0ctober 1992 the city was paying the recycling dealers for each kilogram of ferrous metals diverted from the waste stream.

\subsubsection{Private-Sector Recycling}

Municipalities in Japan have extensive information about the MSW they must treat, but very little data on the amount of material that is diverted from the waste stream by residents and businesses. In addition, the effectiveness of private recycling efforts is not known.

In the mid-1980s, Matsudo City hired Ostrand, Inc., LTD. to help the City prepare its plan for the treatment of General Waste. The 0strand scope of work included designing and conducting surveys of households and businesses within the City to identify the mechanisms used to divert discards, and to estimate the quantity and types of discards so diverted. ${ }^{58}$ The results of the 0strand study, as reported below, provide some valuable insight into private-sector recycling in Matsudo City. ${ }^{59}$

The data regarding private recycling efforts by businesses was obtained by 0strand through an extensive questionnaire survey of businesses in Matsudo City. The survey regarding residential recycling, described in more detail below, involved actual measurements of the weight of residential discards.

The residential survey was conducted from November 10, 1986, through December 9, 1986, and involved 243 of the 143,236 households in the City. The survey had to rely upon volunteer participants; as such, a random or representative sample was not possible. About 30 percent of the participants were City employees or members of consumer groups. As a result, "It can be said that households of employees, consumer groups, and

${ }^{58}$ 0strand, Inc., LTD., Matsudo City-Investigation of Weights of Household Waste: Report (prepared for Matsudo City Department of Sanitation, March 1987), p. l.

${ }^{59}$ 0strand, Inc., LTD., Matsuda City-Basic Plan for General Waste Disposal (Waste Edition) (prepared for Matsudo City Department of Sanitation, March 1988), pp. 33-35. 
the like are relatively more concerned about the garbage problem than the average household." Furthermore, "It can be said that in comparison with the average household, many households in the survey are making an effort to reduce and recycle properly. "60 Therefore, the survey results can reasonably be expected to reflect an upper-bound estimate of recyciing in Matsudo City.

Because the sample of households within the survey was not stratified to reflect the characteristics of all households in Matsudo City, the raw data from this survey was corrected for variables that were shown statistically to affect the quantity of discards, such as the age of the head of the household, the number of persons in the family, the method of collection provided for recyclables, and the type of homes. ${ }^{61}$

Every participating household was provided a scale upon which to weigh their discards. They were asked to provide the weight of each discard, to classify it in accordance with the categories provided in Table 4-5, and to identify the method used to discard the material. The methods were: City-processed or -disposed; privately recycled; self-disposed (including use of garbage disposers, pouring of cooking oil down the kitchen sink, and backyard burning, burying, or composting); and other miscellaneous methods. The percentage use of each of these methods by both households and businesses are summarized in Table 4-6. For that which was designated as having been city-processed or -disposed, households were also asked to identify whether these discards were put out as combustibles, noncombustibles, recyclables, bulky waste, or household hazardous waste. For that which was designated as having been privately recycled, households were asked to identify whether these discards were recycled via recycling dealers; group recycling; returning to retail store (e.g., returnable bottles); giving to friends; or making available for resale (e.g., through resale shops, garage sales, and flea markets). The participant could also provide comments on the data form to further identify the materials being discarded. Also, since the one-month survey would not have been representative of bulky wastes discarded, the survey only recorded the number of bulky items discarded and not their weight.

About 7 percent of total discards were disposed of by the generator (i.e., "self-disposal"). Ostrand did not have a breakdown of types of selfdisposal used by either the households or businesses, but did indicate that it included burning, burying, composting, or disposing down the sink. ${ }^{62}$ A review of the materials identified as having been selfdisposed reveals that about 29 percent of the discards that were selfdisposed were kitchen wastes, which may reasonably be assumed to have been

${ }^{60}$ Ostrand, Inc., LTD., Matsudo City-Investigation of Weights of Household Waste: Report, p. 12 .

${ }^{61}$ Ostrand, Inc., LTO., Matsudo City-Investiqation of Wejghts of Household Waste, p. 9.

${ }^{62}$ Ryoko Sugiyama to A1an S. Cohen, letter, December 9, 1992. 
TABLE 4-5

TABLE OF STANDARDS OF CLASSIFICATIONS FOR "REDUCATION AND RECYCLING," INVESTIGATION INTO THE ACTUAL CONDITIONS OF WASTE DISPOSAL

\begin{tabular}{|c|c|c|}
\hline ITEM & $\begin{array}{l}\text { CLASSIFICATION } \\
\text { INVESTIGATION }\end{array}$ & EXAMPLES \\
\hline \multirow[t]{5}{*}{$\begin{array}{l}\text { Combustible } \\
\text { Waste }\end{array}$} & a. Raw Garbage & $\begin{array}{l}\text { Left-over food, cooking refuse (vegetabies, } \\
\text { fruit, meat, fish, tea leaves, left-over } \\
\text { rice, eggshells, etc.) - excepting shellfish } \\
\text { shells, containers, etc. (1andfitl waste). }\end{array}$ \\
\hline & $\begin{array}{l}\text { b. Waste Paper, } \\
\text { Wood Shavings, } \\
\text { etc. }\end{array}$ & $\begin{array}{l}\text { Toilet paper, wooden chopsticks, cigarette/ } \\
\text { cigar butts, corks, carbon paper, bamboo } \\
\text { skewers, dead trees, cardboard tops of milk } \\
\text { bottles, etc. }\end{array}$ \\
\hline & c. Paper Cartons & $\begin{array}{l}\text { Milk cartons, yogurt cartons, juice cartons, } \\
\text { etc. }\end{array}$ \\
\hline & d. Paper Diapers & $\begin{array}{l}\text { Disposable diapers made of paper, synthetic } \\
\text { fibers. }\end{array}$ \\
\hline & $\begin{array}{l}\text { e. Left-Over } 0 i 1 \\
\text { from Cooking }\end{array}$ & 0il that remains from cooking tempura, etc. \\
\hline $\begin{array}{l}\text { Noncombustible } \\
\text { Waste }\end{array}$ & f. Landfil1 Waste & $\begin{array}{l}\text { Ashes, petrochemical products such as } \\
\text { expanded polystyrene, vinyl, nylon, etc. } \\
\text { (packaging for fish, meat, vegetables; } \\
\text { plastic containers for seasonings, liquid } \\
\text { yogurt, etc.) rubber products (sneakers, } \\
\text { sandals, etc.), relatively small composite } \\
\text { items composed primarily of plastic } \\
\text { (disposable lighters, lipstick, etc.), } \\
\text { pottery, shells, leather, rugs up to a size } \\
\text { of } 4.5 \text { tatami mats, carpeting. }\end{array}$ \\
\hline $\begin{array}{l}\text { Recyclable } \\
\text { Waste }\end{array}$ & $\begin{array}{l}\text { 9. Paper } \\
\text { (Recyclable) }\end{array}$ & $\begin{array}{l}\text { Newspaper, magazines, leaflets, wrapping } \\
\text { paper, notepaper, cardboard boxes, clothes } \\
\text { boxes, shoeboxes, etc. - excepting specially } \\
\text { processed paper such as carbon paper (high- } \\
\text { calorie waste), plastic film (landfill } \\
\text { waste), etc. }\end{array}$ \\
\hline
\end{tabular}


TABLE 4-5 (CONTINUED)

TABLE OF STANDARDS OF CLASSIFICATIONS FOR "REDUCATION AND RECYCLING," INVESTIGATION INTO THE ACTUAL CONDITIONS OF WASTE DISPOSAL

ITEM

CLASSIFICATION

INVESTIGATION

EXAMPLES

Recyclab]e Waste (cont.)

Bulky Waste

Hazardous Waste

Waste that is Difficult to Classify h. Textiles

- pure cotton

- pure wool

- synthetic fibers

i. Bottles, Glass

j. Metals

- ferrous

- non-ferrous

k. Household

Electrical

Appliances, etc.

1. Bulky Waste

m. Hazardous Waste

n. Composite Products
Items of light fabric, such as pants, skirts, suits, shirt, and sheets, and wool items such as sweaters - excepting heavy items, such as leather products, rugs, etc. (1 andfill waste).

Bottles for soy sauce, sake, beer, whiskey, wine, juice, cola, Calpis, health drinks, etc.; plate glass, bottles for oil; broken glass - lids should be separated and divided according to material (1 andfill waste).

Household metal products (frying pans, pots, kettles, etc.), iron cans (canned oil, canned foods, canned juice, canned milk, etc.), gaTvanized iron sheets, etc. - excepting spray cans and cans caked with foreign matter (1 andfill waste).

A7uminum (empty cans, beer kegs, etc.), stainless steel.

Refrigerators, washing machines, televisions, stereos, stoves, bicycles, tricycles, strollers, etc.

Bureau, beds, sofas, rugs the size of 6 tatami mats or larger, carpeting, doors, sliding room partitions, etc.

Thermometers, batteries, fluorescent lightbulbs.

Products composed of $\mathrm{plastic/glass/fabric/}$ metal (boats, umbrellas, etc.), other products that do not fit into any of the above categories.

NOTE: This table of standards of classification is limited to the period of the investigation. 
TABLE 4-6

MATSUDO CITY: METHODS OF DISPOSING OF RESIDENTIAL AND COMMERCIAL DISCARDS: 1986

(percent)

\begin{tabular}{|c|c|c|c|}
\hline CATEGORY & TOTAL & RESIDENTIAL & COMMERCIAL \\
\hline \multicolumn{4}{|l|}{ Including Self-Disposal } \\
\hline \multirow[t]{2}{*}{$\begin{array}{l}\text { City Processing/Disposal } \\
\text { Private Recycling } \\
\text { Self Disposal } \\
\text { Export to 0ther Cities } \\
\text { Other/Miscellaneous }\end{array}$} & $\begin{array}{r}54.9 \\
23.9 \\
7.1 \\
13.1 \\
1.1 \\
\end{array}$ & $\begin{array}{r}70.6 \\
19.1 \\
9.1 \\
0.0 \\
1.3 \\
\end{array}$ & $\begin{array}{r}36.7 \\
29.4 \\
4.8 \\
28.1 \\
1.0 \\
\end{array}$ \\
\hline & 100.0 & 100.0 & 100.0 \\
\hline \multicolumn{4}{|l|}{ Excluding Self-Disposal } \\
\hline \multirow[t]{2}{*}{$\begin{array}{l}\text { City Processing/Disposal } \\
\text { Private Recycling } \\
\text { Export to Other Cities } \\
\text { Other/Miscellaneous }\end{array}$} & $\begin{array}{r}59.0 \\
25.7 \\
14.1 \\
1.2 \\
\end{array}$ & $\begin{array}{r}77.6 \\
21.0 \\
0.0 \\
1.4 \\
\end{array}$ & $\begin{array}{r}38.6 \\
30.8 \\
29.5 \\
1.1 \\
\end{array}$ \\
\hline & 100.0 & 100.0 & 100.0 \\
\hline
\end{tabular}

Source: Matsudo City "Basic Plan for General Waste (Waste Edition)," March 1988. 
disposed of down the kitchen sink, buried in gardens, or composted. The remainder of the material, including paper, wood, plastics, and glass, most likely was burned or buried. Sixty percent of the self-disposed discards consisted of miscellaneous paper and wood.

Because the actual methods of disposition of the self-disposed material is unknown (as is also usually the case in the U.S.) the estimates of gross discards, generation rates, and recycling rates that follow will exclude materials that are self disposed.

Commercial establishments indicated that about 28 percent of their discards are exported to other cities. This large percentage of exports reflects the fact that Matsudo City has limited landfill capacity and therefore also exports most of the MSW and ash it landfills to locations outside its jurisdiction.

Exclusive of those discards that are self-disposed, about 26 percent of the City's total discards were privately recycled. Households privately recycled an estimated 21 percent of their discards, while businesses privately recycled an estimated 31 percent of their discards.

During 1986, households used a wide variety of methods to privately recycle their discards. About 59 percent was diverted directly through recycling dealers, and 19 percent through group recycling. Another 20 percent was recycled through returns of reusable bottles and some appliances to retail establishments. Only about 2.4 percent was given to friends, and less than 1 percent was resold in resale shops, garage sales, and flea markets.

over 93 percent of the residential discards recycled through recycling dealers consisted of newspapers, magazines, and cardboard. Similarly, about 88 percent of the household discards recycled through group recycling consisted of newspapers, magazines, and cardboard. About 60 percent of the what households returned to stores were reusable bottles. Many of these bottles were liquor bottles (beer, sake, and whiskey), the recycling of which is facilitated by the fact that they are often delivered to and picked up at the household by the local liquor retail outlets. The small percentage of discards given to friends or resold is indicative of the Japanese propensity for buying new rather than utilizing used items.

Over 70 percent of the privately recycled residential discards were newspapers, magazines, and cardboard; another 13 percent was reusable bottles. In total, the private recycling of these materials, which are typically included in U.S. recycling programs, represented about 84 percent of the private recycling from households in Matsudo City. The predominance of the remaining private recycling is of used appliances, furniture, and clothing. In the U.S. these items are typically recycled through garage sales, flea markets, and organizations such as the Salvation Army and Goodwill Industries. 
Businesses use recycling dealers to a greater extent than do households. About 72 percent of the commercial discards that were recycled in 1986 were recycled through recycling dealers. The recycling dealers take a wide variety of materials from businesses, including a significant amount of composite or unclassified materials. Paper, including newspapers, magazines, and cardboard, made up about 35 percent of the materials businesses diverted through recycling dealers. Virtually all of the remaining privately recycled commercial discards (i.e., those not recycled through recycling dealers), about 27 percent, were returned to stores or distributors. About 95 percent of these discards were reusable bottles. The distribution system, whereby returnable bottles are picked up when deliveries are made to restaurants, bars, and hotels, contributes significantly to the high percentage of recyclables returned to stores or distributors.

About 66 percent of privately recycled commercial and residential discards were recycled through recycling dealers, 8 percent through group recycling, 24 percent through returns to stores or distributors, and 1 percent by other means.

\subsubsection{Total Discard Generation and Recycling}

By combining the Ostrand and City FYgo data estimates of total discards, the per capita generation rate and recycling rates can be estimated for FY90. These estimates take into account the increase in the quantity of MSW generated (from 117,000 tonnes in 1986 to 142,000 tonnes in 1990); the increase in the percentage contributions of total MSW treated by the city from businesses (from 23 percent in 1986 to 26 percent in $1990^{63}$ ); and the increase in the quantity of recyclable materials recovered by the city from MSW (from 7.1 percent in 1986 to 9.2 percent in $1990^{64}$ ). These estimates assume that the ratio of MSW to total discards, the composition of the materials privately recycled, and the rate of private recycling remain constant for households and businesses from 1986 to 1990 , i.e., they are based on the ostrand results.

The quantity of total MSW treated by Matsudo City in FY90 was 142,000 tonnes, of which 102,800 tonnes were from residences. Multiplying the quantity of Residential MSW by 1.29 (the ratio of total discards, excluding self-disposed discards, to Residential MSW, as determined by the 0strand study) results in an estimated 133,000 tonnes of residential discards. Similarly, multiplying the balance of MSW treated by the City by 2.59 (the ratio of total discards, exclusive of self-disposed discards, to Commercial MSW treated by the City) results in an estimated 102,000 tonnes of commercial discards. The estimated FY90 quantity of total

${ }^{63}$ Matsudo City Department of Sanitation, Matsudo City-Survey of Cleansing Operations, Fiscal Year I991 (undated), pp. 33 and 51.

${ }^{64} \mathrm{Calculated}$ from Matsudo City-Survey of Cleansing Operations, Fiscal Year 1991, pp. 32 and 49. 
discards is 235,000 tonnes. The FY90 per-capita generation rate for the 450,000 persons living in Matsudo City was 0.52 tonnes per person (i.e., 3.1 pounds per person per day).

The estimated composition of these discards is presented in Table 4-7. The composition data indicate the relatively large percentage of kitchen or food waste in Matsudo City's discards and the relatively small amounts of yard waste (miscellaneous paper and wood includes some yard waste). This is typical of residential and commercial discards throughout Japan. over 33 percent of the discards generated in Matsudo city consisted of recycled paper (primarily newspaper, magazines, and cardboard), glass, and metals. Excluding kitchen waste, these materials represent over 52 percent of the discards.

Table 4-8 provides the estimated quantities of recyclable materials recovered in $\mathrm{FY} 90$ from the 235,000 tonnes of total discards. The estimates in this table were used to develop Figures 4-5 and 4-6. Figure 4-5 shows the composition of the recycled materials. Figure 4-6 shows the percentage of each material privately recovered from residences, commercial establishments, and the City's recycling program.

The total estimated recycling rate within Matsudo City in FY90 was 31 percent, as shown in Table 4-9. It is particularly interesting that over 80 percent of the material recycled consisted of paper (primarily newspaper, magazines, and cardboard), glass beverage containers (reusable bottles and cullet), and metals (ferrous and aluminum). These are the same types of materials typically included in recycling programs in the United States. The success of the recycling program in Matsudo City can be attributed to the high capture rates for these materials and the relatively high concentrations of these materials in the total discards.

About 20 percent of the recovered materials were reusable bottles, which illustrates the impact on recycling of the deposit system in Japan. Over 72 percent of these bottles were recovered from commercial establishments such as restaurants, bars, and hotels.

The relative cost of the two-way bottle system and the trend toward aluminum cans and plastic bottles will likely reduce the use of reusable bottles in Japan. This would have a significant impact on Japanese recycling programs. The merits of a nationwide mandatory deposit law are currently being studied. ${ }^{65}$ The Japanese are particularly interested in the U.S. experience with "bottle bills."

The City's recycling program captures the bulk of cullet (primarily broken beverage containers) and metals. A significant portion of the metals are recovered from the magnetic separation of steel cans from the noncombustible waste stream and the recovery of ferrous scrap from shredded appliances and bicycles.

${ }^{65} \mathrm{Al}$ an S. Cohen and members of the Clean Japan Center, Federation of Glass Bottle Recycling, and Japan Used-Can Treatment Association, discussions, October 1992. 
TABLE $4-7$

MATSUDO CITY: ESTIMATED COMPOSITION OF TOTAL DISCARDS (percent, wet basis)

\begin{tabular}{lrrr}
\hline CATEGORY & TOTAL & RESIDENTIAL & COMMERCIAL \\
\hline & & & \\
Kitchen Waste & 36.0 & 37.5 & 37.7 \\
Paper (Recyclable) & 16.5 & 17.0 & 9.5 \\
Misc. Paper and Wood & 12.7 & 13.7 & 11.7 \\
Glass & 12.1 & 13.7 & 11.7 \\
Metals & 5.0 & 3.4 & 4.1 \\
Plastics & 4.7 & 5.8 & 1.3 \\
Textiles & 1.5 & 1.9 & 7.2 \\
Composite Material & 3.7 & 0.6 & 9.9 \\
Other Miscellaneous & 7.8 & 6.4 & 100.0 \\
Total & 100.0 & 100.0 & -1 \\
\hline
\end{tabular}

Source: Matsudo City "Basic Plan for General Waste (Waste Edition)," March 1988. 
TABLE $4-8$

MATSUDO CITY: ESTIMATED QUANTITIES OF RECYCLABLE MATERIALS RECOVERED FROM TOTAL DISCARDS - FISCAL YEAR 1990 (tonnes per year) ${ }^{1,2}$

\begin{tabular}{|c|c|c|c|c|}
\hline \multirow[t]{2}{*}{ CATEGORY } & \multirow[t]{2}{*}{ TOTAL } & \multirow{2}{*}{$\begin{array}{l}\text { MUNICIPAL } \\
\text { RECYCLING }\end{array}$} & \multicolumn{2}{|c|}{ PRIVATE RECYCLING } \\
\hline & & & RESIDENTIAL. & COMMERCIAL \\
\hline $\begin{array}{l}\text { Paper } \\
\text { Reusable Bottles } \\
\text { Glass Cullet } \\
\text { Metals } \\
\text { Textiles } \\
\text { Other/ } \\
\text { Miscellaneous }\end{array}$ & $\begin{array}{r}30,500 \\
14,600 \\
4,870 \\
9,620 \\
2,160 \\
11,500 \\
\end{array}$ & $\begin{array}{r}3,170 \\
640 \\
3,970 \\
4,130 \\
550 \\
\\
560 \\
\end{array}$ & $\begin{array}{r}18,400 \\
3,320 \\
130 \\
220 \\
1,260 \\
2,520 \\
\end{array}$ & $\begin{array}{r}8,980 \\
10,600 \\
770 \\
5,270 \\
360 \\
8,440 \\
\end{array}$ \\
\hline $\begin{array}{l}\text { Total Recyclable } \\
\text { Materials Recovered }\end{array}$ & 73,300 & 13,000 & 25,800 & 34,400 \\
\hline (Total Discards & & & & \\
\hline
\end{tabular}

1 Based on data from: Matsudo City "Basic Plan for General waste (Waste Edition)," March 1988, and "Survey of Cleaning Operations (Sanitation)," Fiscal Year 1991.

2 Numbers have been rounded to three significant figures. Totals have al so been rounded to three significant figures, therefore columns do not add. 


\section{FIGURE 4-5: MATSUDO CITY-COMPOSITION OF RECOVERED RECYCLABLES}

MATERIALS: FISCAL YEAR 1990

(percent by weight)

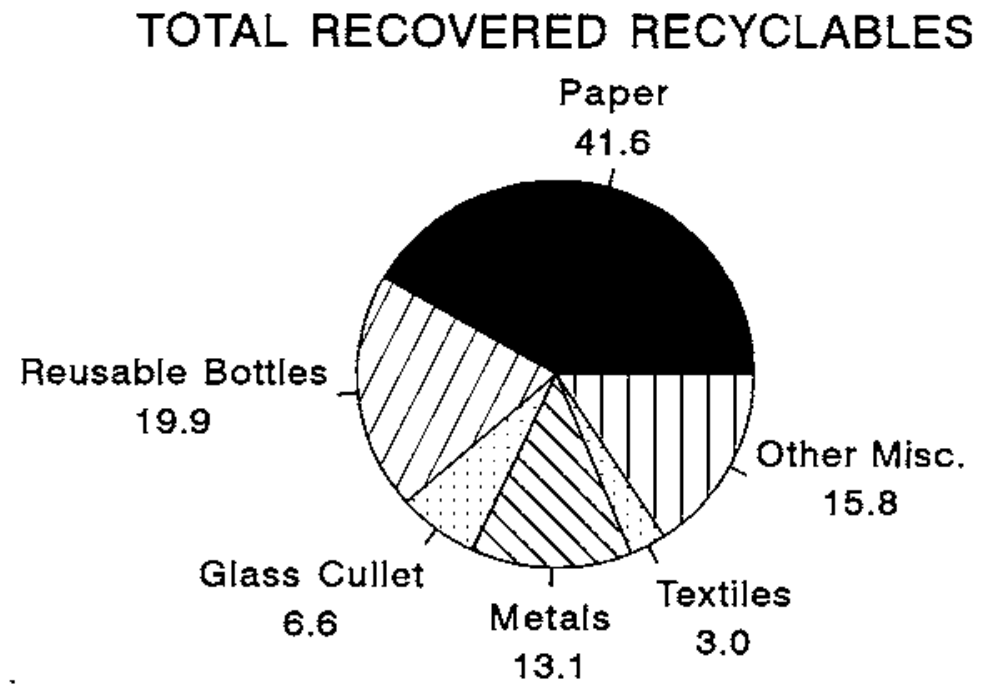

MUNICIPALLY RECYCLED MATERIALS

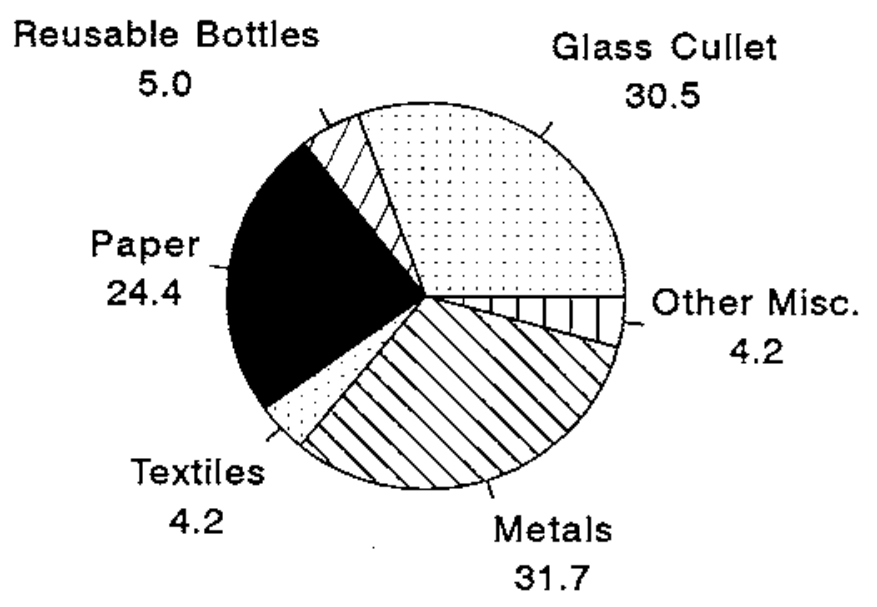

\section{COMMERCIAL PRIVATELY RECYCLED RECYCLABLES}

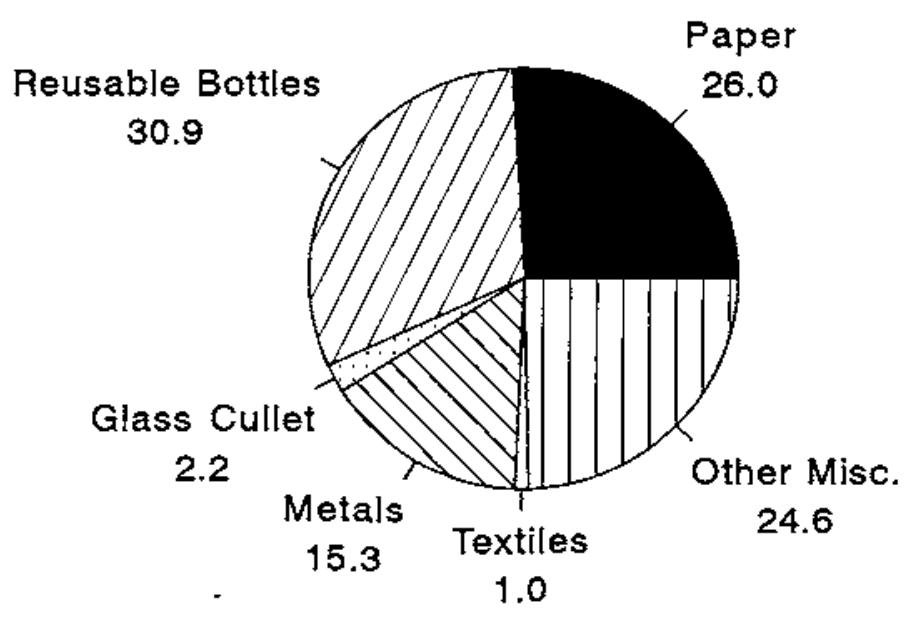

\section{RESIDENTIAL PRIVATELY RECYCLED RECYCLABLES}

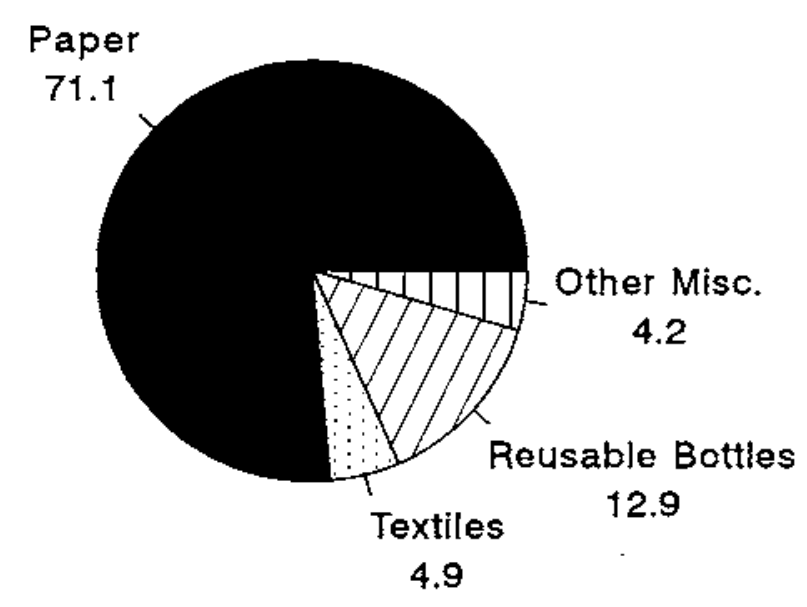

SOURCE: Matsudo City, "Basic Plan for General Waste (Waste Edition)," March 1988. 
FIGURE 4-6: MATSUDO CITY-SOURCES OF RECOVERED RECYCLABLE MATERIALS:

FISCAL YEAR 1990

(percent by weight)

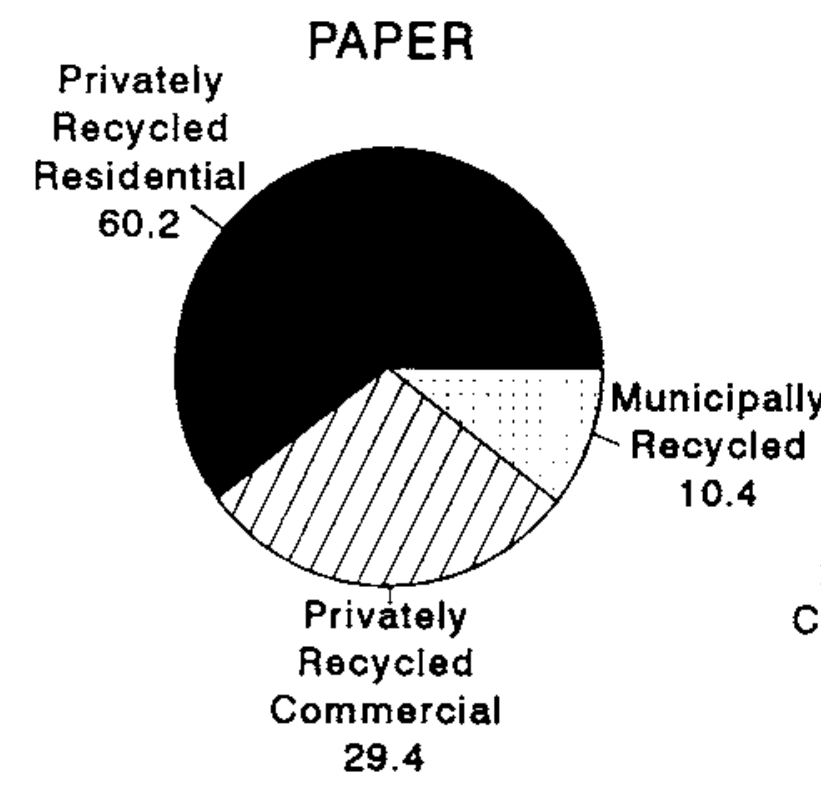

REUSABLE BOTTLES

Privately

Recycled

Residential

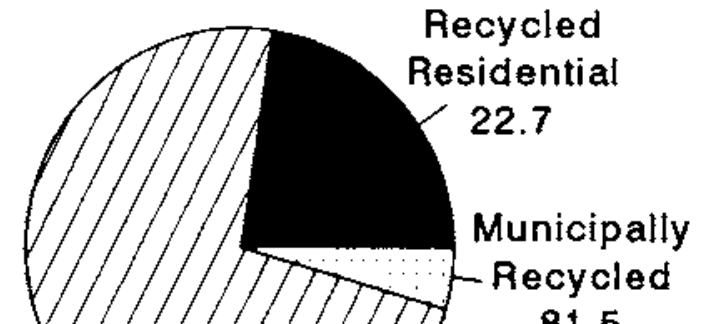

81.5

Privately

Recycled

Commercial

72.8

\section{GLASS CULLET}

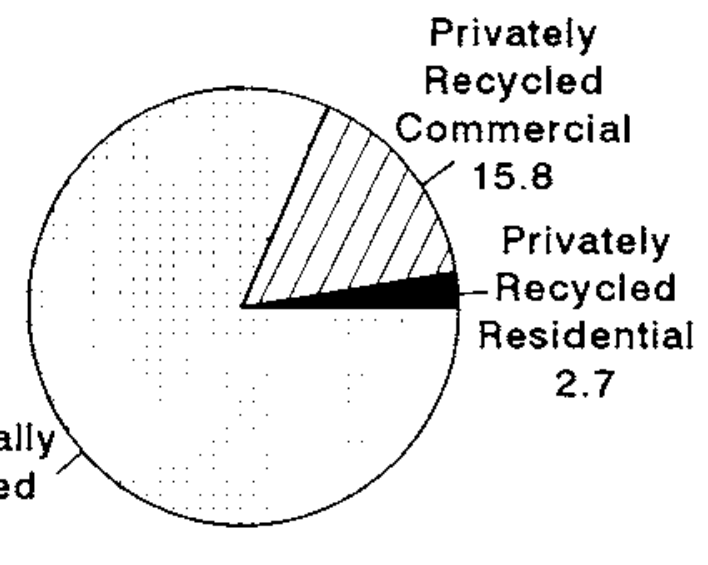

29.4
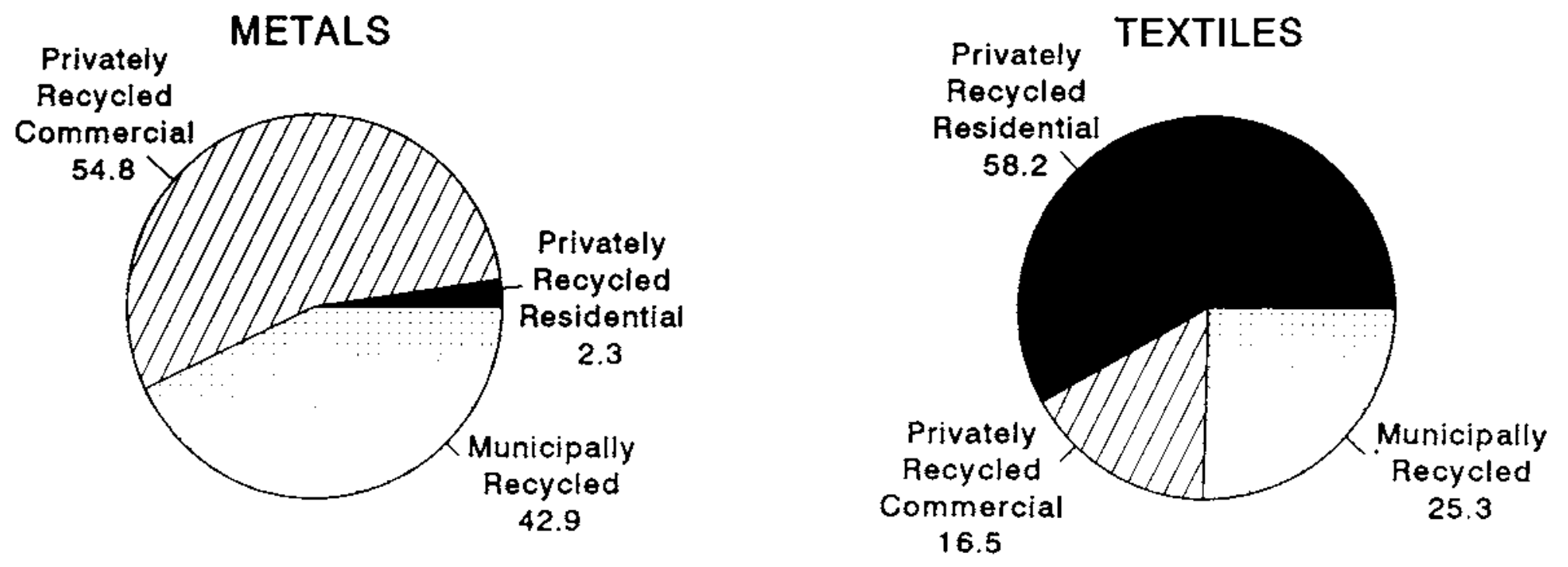
TABLE $4-9$

MATSUDO CITY: ESTIMATED RECYCLING RATES - FISCAL YEAR 1990 (percent of total discards)

\begin{tabular}{|c|c|c|c|c|}
\hline \multirow[t]{2}{*}{ CATEGORY } & \multirow[t]{2}{*}{ TOTAL } & \multirow{2}{*}{$\begin{array}{l}\text { MUNICIPAL } \\
\text { RECYCLING }\end{array}$} & \multicolumn{2}{|c|}{ PRIVATE RECYCLING } \\
\hline & & & Residential & Commercial \\
\hline $\begin{array}{l}\text { Paper } \\
\text { Reusable Bottles } \\
\text { Glass Cullet } \\
\text { Metals } \\
\text { Textiles } \\
\text { Other/Misc. }\end{array}$ & $\begin{array}{r}13.0 \\
6.2 \\
2.1 \\
4.1 \\
0.9 \\
4.9 \\
\end{array}$ & $\begin{array}{l}1.4 \\
0.3 \\
1.7 \\
1.8 \\
0.2 \\
0.2 \\
\end{array}$ & $\begin{array}{l}7.8 \\
1.4 \\
0.1 \\
0.1 \\
0.5 \\
1.1 \\
\end{array}$ & $\begin{array}{l}3.8 \\
4.5 \\
0.3 \\
2.2 \\
0.2 \\
3.6 \\
\end{array}$ \\
\hline $\begin{array}{c}\text { Total Recovered } \\
\text { Recyclable } \\
\text { Materials }\end{array}$ & 31.2 & 5.5 & 11.0 & 14.7 \\
\hline (Total Discards & $235,000)$ & & & \\
\hline
\end{tabular}

Based on data from Matsudo City "Basic Plan for General Waste (Waste Edition), "March 1988, and "Survey of Cleaning Operations (Sanitation)," Fiscal Year 1991. 


\subsubsection{Summary}

The 0strand study provides a unique opportunity to estimate the FY90 quantity of total discards generated in Matsudo City and the methods used to manage the City's total MSW stream. of the total discards, an estimated 46 percent was combusted; 31 percent was recycled; less than 0.01 percent was treated as Household Hazardous Waste (i.e., dry cell] batteries, thermometers, and fluorescent Tight bulbs); and 23 percent, exclusive of ash disposal, was landfilled.

During FY90, the City's integrated MSW system, exclusive of the Citysupported group recycling activities, treated about 61 percent of the totaT discards generated in the City. of this MSW, approximately 76 percent was combusted; 9.2 percent was recycled; Tess than 0.01 percent was treated as household hazardous waste; and 15 percent (exclusive of ash) was landfilled.

\section{$4.3 \quad$ HIRATSUKA CITY}

Hiratsuka City is one of 37 municipalities in the Kanagawa Prefecture, the largest of which is Yokohama City. With a 1990 population of about 244,000 persons and a population density of about 3,590 persons per square kilometer (or about 9,310 persons per square mile), Hiratsuka City is considered a small- to medium-sized urbanized city. ${ }^{66}$ The "Hiratsuka Method" of increasing the amount of discards recycled from households is well known in Japan and is described in Section 4.3.2. A general overview of Hiratsuka's MSW management program is presented below in Section 4.3.1.

\subsubsection{MSW Generation and Description of the Treatment System}

Figure 4-7 is a flow diagram illustrating the MSW management system in Hiratsuka City. Including the 14,200 tonnes collected through Citysponsored group recycling, a total of 91,358 tonnes of discards were managed by the City in FY90. The composition of the 71,160 tonnes of MSW is provided in Table 4-10. Of particular interest is the relatively large quantity of wood, bamboo, and straw (i.e., yard waste) in this waste stream. This is indicative of the relatively low population density of the area.

Ninety-five percent of the 77,160 tonnes of MSW in FY90 was combusted, with energy recovery. Taking into account the group recyciing program, 80 percent of the 91,358 tonnes of discards were combusted. Bulky waste and noncombustibles were shredded and classified to recover ferrous, aluminum, and combustibles. Ferrous was also recovered from the combustion ash. In total, about 17 percent of the 91,358 tonnes of total discards were recovered for recycling. This does not include recyclables recovered

\footnotetext{
${ }^{66}$ Council of Local Authorities for International Relations, Japan Local Government Data Book 1991 (March 1992), p. 66.
} 
FIGURE 4-7: HIRATSUKA CITY MSW FLOW DIAGRAM: FISCAL YEAR 1990 (tonnes)

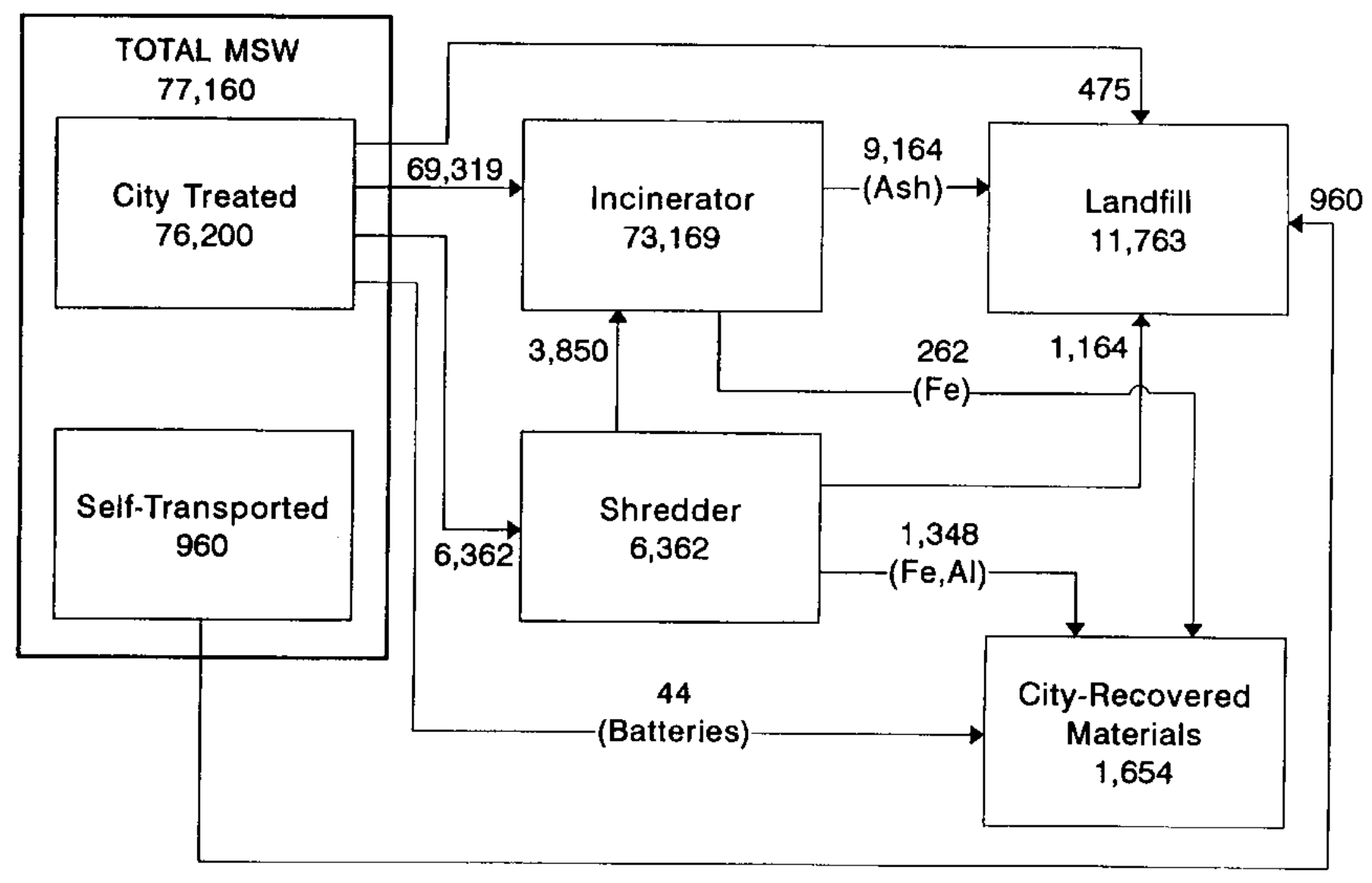


TABLE 4-10

HIRATSUKA CITY: COMPOSITION OF CITY-TREATED MSW: FISCAL YEAR 1990

(percent by weight-dry basis)

\begin{tabular}{lc}
\hline & PERCENT \\
\hline ITEM & \\
\hline Food Waste & 14.7 \\
Paper/Textiles & 39.9 \\
Plastic/Rubber/Leather & 16.8 \\
Wood/Bamboo/Straw & 10.7 \\
Noncombustibles & 9.8 \\
Other & 8.1 \\
& 100.0 \\
\hline
\end{tabular}

Source: $\quad$ "Summary of Sanitation Operations," Hiratsuka City, 1991. 
through other, private-sector recycling activities, such as the newspaper recycling program supported by newspaper publishers.

Combustion occurs at the 294-tonne-per-day (24-hour) fluidized bed wasteto-energy facility, completed in 1988. This three-unit facility is known as the 0kami Environmental Sanitation Center and also treats sewage sludge. Hot water generated at the facility is used at the neighboring community welfare center. The facility was built for a reported 4.4 billion yen (about $\$ 33$ million), of which slightly less than half was subsidized by the national government. ${ }^{67}$ The Fy90 operating and maintenance costs, exclusive of labor, are reported to have been 306 million yen (about $\$ 2.88 \mathrm{million}$ ). This is equal to 4,200 yen per tonne (about $\$ 28$ per ton). ${ }^{68}$ of this amount, about 40 percent was for the purchase of electrical power. The facility is staffed with 39 persons: 3 general, 35 technical, and 1 miscellaneous positions.

The "crushing," or shredding, facility was completed in April 1989 and uses a horizontal rotary impact shear shredder, rated at 11 tonnes per hour, to shred bulky and noncombustible Residential MSW. During FY90, about 61 percent of the material shredded was recovered as combustibles for processing at the waste-to-energy plant; about 21 percent was recovered as aluminum and ferrous metals for recycling; and the remaining 18 percent was sent to the landfill for disposal. " The facility was built for a reported 945 million yen (about $\$ 7.0 \mathrm{million}$ ). About 48 percent of this amount came from the national treasury, and 7 percent came from the prefecture treasury. ${ }^{70}$ The FY90 operating and maintenance cost, exclusive of labor, is reported to have been 61 million yen (about $\$ 460,000)$. The facility is staffed with two general and six technical people.

A new cell with a capacity of 223,000 cubic meters was opened at the City's landfill in March 1984 for a reported construction cost of 735 million yen (about $\$ 5.5$ million). The landfill has a synthetic liner and a leachate collection and treatment system. The closed cell has been made into a playground.

${ }^{67}$ City of Hiratsuka, "Summary of Sanitation Operations" (Department of the Environment, Fiscal Year 1991), p. 36.

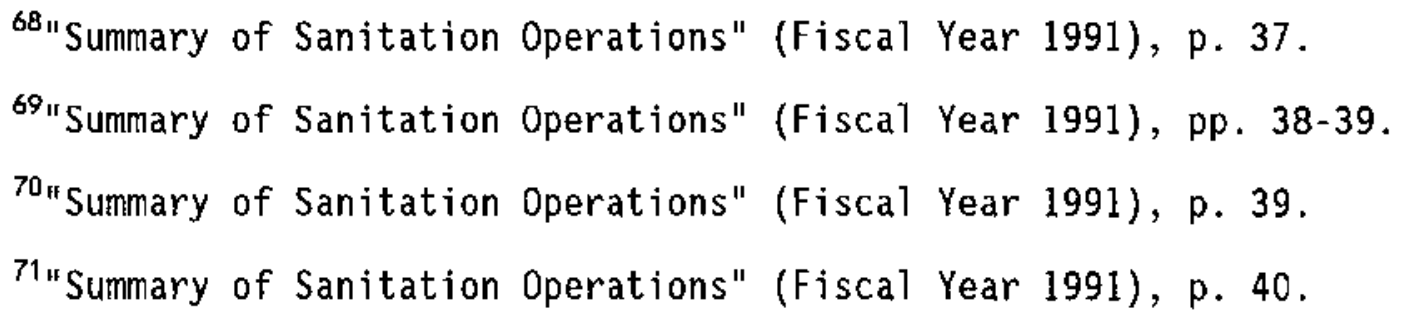




\subsubsection{The "Hiratsuka Method" of Recycling}

Following the oil embargo of 1973, many Japanese communities with populations of less than 300,000 began to sponsor and implement residential resource recovery programs. These programs were primarily restricted to smaller communities because "the degree of cooperation of residents through actual participation varies from one city to another, or even one district to another in the same city, depending on the nature of the communities concerned. For this reason, a highly urbanized large Japanese city is generally reluctant to practice source separation, while the authority of a smal1- or medium-sized urbanized city considers it relatively more feasible. "72 Many of these programs are referred to by the name of the community that first implemented them, such as the "Hiratsuka Method."

The willingness of communities to implement source-separation programs today a7so appears to be size-related. For example, many of the larger cities, such as Kawasaki, Yokohama, Kyoto, Osaka, and Kobe, do not even require residents to separate their waste into combustible and noncombustible fractions. The City official of Hiratsuka recently stated the situation this way:

The scales of municipalities are composed of (1) population and its density, (2) areas of municipalities and population distribution, [and] (3) progressive state of urbanization. These factors are important for the unity of regional people, and the regional unity is directly concerned in the cooperative system with municipalities, as well as that with groups. This is particularly important when citizens are asked to bear the burdens.

Fortunately, Hiratsuka City is a medium city, and citizens' cooperation is considered to be given fully, as a result of which a conclusion was reached to the effect that the separation at generated sources was the best method in order to reduce quantities of waste by resources recycling and preserve the environment. From this point of view, it is conceived quite sure that the burdens will be shared by citizens.

Recognizing their benefits, the City began to subsidize group recycling activities in 1977. The direct payment to group recyclers for the materials they divert from the waste stream is referred to as the Hiratsuka Method. The quantity of materials recovered under this method

${ }^{72}$ S. Gotoh, E. Tanaka, and Y. Yonemura, "Source Separation for Resource Recovery - State of the Art, " Conservation and Recycling: Vol. 3 (Great Britain, Pergamon Press, 1980), pp. 305-317.

1 .

${ }^{73}$ "Separation Collections as Official Duties by Municipalities," p. 
leveled off at about 5,000 tonnes per year in 1982. In 1983 the City established a committee to study the program and make suggestions to improve its effectiveness. In 1983 the City began pilot programs of what has become the "New Hiratsuka Method," which was fully implemented in 1986. In FY90, over 14,000 tonnes were diverted from the MSW stream via the New Hiratsuka Method.

The original Hiratsuka Method required recycling groups to register with the city. Such groups could be citizens councils, PTAs, children's groups, senior citizens clubs, or other civic organizations. Each group determined a suitable location for the collection station in its neighborhood and was responsible for providing supervisors during collection days. The collection days and times were determined through negotiations with each group and the recycling dealers. The groups would then inform the city of the collection days and times. The dealers paid the City the market price they would have paid the groups without the City involvement, and the City in turn paid the groups a flat subsidy of 8 yen per kilogram of each material recovered. In essence, the City purchased the material from the citizens groups for a flat guaranteed fee and then sold the material to the recycling dealers at market prices, which on average are usually below the price paid to the groups.

During the nine years between 1977 and 1985, just over 34,000 tonnes of material were diverted from the waste stream by the registered groups. The City's net subsidy over this period is reported to have been about 100 million yen (about $\$ 750,000$ ) or about 3,000 yen per tonne (about $\$ 27$ per ton). (Note: These figures do not reflect the time value of money over the nine-year period.)

The original Hiratsuka Method was viewed as being inefficient because only registered groups participated and collections occurred irregularly or, at best, once every two months. As a result, participation was not Citywide, and, because of storage limitations, many potential recyclables were discarded in the more frequent collections of combustible (twice a week) and noncombustible (twice a month) waste. Also, competition among recycling dealers to collect the material often resulted in what the Japanese referred to only as "evils" that reduced the efficiency of the program. Presumably, such evils might have included such things as fights among the dealers or even illegal activities aimed at increasing a dealer's share of the materials recovered.

The New Hiratsuka Method collects source-separated recyclables twice a month on a specified schedule. Furthermore, the stations used as collection points for combustible and noncombustible waste were also established as permanent locations for the group recycling collections, although such collections are not conducted on the same day. Each station services about 50 families, and all residents of the city can now participate in the program.

The night before each scheduled recyclable material collection day, the City places City-supplied containers at each station. Sufficient wire mesh and stackable containers are provided to allow the citizens to 
segregate at the station, reusable bottles, color-sorted broken bottles and other glass containers, steel cans, aluminum cans, and other ferrous and nonferrous discards. Newspapers, magazines, milk cartons (cleaned and cut open), and clothing must be neatly tied or bundled and placed in designated areas next to the containers.

Citizens' Councils elect representatives to supervise the stations during recyclable material collection days. The supervisors make sure that the material is properly sorted and that the area stays neat and clean. Toward the end of the day, city-designated recycling dealers pick up the recovered material. More than one dealer may come to each station to pick up specific types of materials. Finally, at the end of the day the city workers pick up any discards that were not recyclable and were left behind, pick up any empty containers, and clean the site.

The heart of the program is still the 8-yen payment per kilogram of material diverted by the recycling groups. Groups no longer need to register with the City. Rather, all payments are made to the Citizens' Councils, which control most of the private organizations in the city. Although the City still receives payments from the recycling dealers, during times of poor market conditions the City now provides a pricesupport subsidy to the dealers. The relatively high subsidy to the recycling groups and the price supports to the recycling dealers result in high participation rates and provide stability to the system, particularly when markets for the recovered goods are poor.

Through the new Hiratsuka Method, Hiratsuka City diverted 14,198 tonnes of materials in FY90. The distribution of recyclable materials collected from FY85 (the last year of use of the original Hiratsuka Method) through FY90 is shown in Table 4-11 and Figure 4-8. On average, about 10,000 tonnes of recyclables were recovered from FY86 through FY88. An aggregate increase of about 42 percent occurred from FY88 through FY90. This increase can be attributed to a number of factors, including increased consumption and increased recycling rates. It is also attributable to a substitution of the Hiratsuka Method for other recycling activities. For example, there was an increase in the amount of paper recovered through the Hiratsuka Method, which reflects a decrease in the amount of newspaper being collected for recycling by newspaper companies and, possibly, an increase in the illegal disposal of commercial waste paper at the stations. ${ }^{74}$

Since the implementation of the New Hiratsuka Method, the most significant impact on the City's integrated MSW management system has been the sharp reduction in the quantity of material going to the shredding facility. Between 1985 and 1986, the year the New Hiratsuka Method was fully implemented, the tonnage received at the shredding facility dropped from 11,200 tonnes to 6,760 tonnes. At the same time, the quantity of material recovered from $C$ ity-subsidized group recycling increased from 4,980 tonnes

9.

${ }^{74 " S e p a r a t i o n ~ C o l l e c t i o n s ~ a s ~ O f f i c i a l ~ D u t i e s ~ b y ~ M u n i c i p a l i t i e s ", ~ p . ~}$ 
TABLE 4-11

HIRATSUKA CITY: DISTRIBUTION OF RECYCLABLES COLLECTED - FISCAL YEARS 1985-1990

\begin{tabular}{|c|c|c|c|c|c|c|c|c|c|c|c|c|c|c|c|c|}
\hline \multirow{2}{*}{$\begin{array}{l}\text { FISCAL } \\
\text { YEAR }\end{array}$} & \multirow[t]{2}{*}{ \# GROUPS } & \multirow[t]{2}{*}{ \# COLLECTIONS } & \multicolumn{2}{|l|}{ PAPER } & \multicolumn{2}{|c|}{ MAGAZINES } & \multicolumn{2}{|c|}{ TEXTILES } & \multicolumn{2}{|c|}{ FERROUS } & \multicolumn{2}{|l|}{ GLASS } & \multicolumn{2}{|l|}{ OTHER } & \multicolumn{2}{|l|}{ TOTAL } \\
\hline & & & Tonnes & $\%$ & Tonnes & $\%$ & Tonnes & $\%$ & Tonnes & $\%$ & Tonnes & $\%$ & Tonnes & $\%$ & Tonnes & $\%$ \\
\hline 1985 & 324 & 1,934 & 2,102 & 42 & 713 & 14 & 202 & 4 & 866 & 17 & 325 & 7 & 744 & 16 & 4,983 & 100 \\
\hline 1986 & 428 & & 2,674 & 30 & 1,219 & 14 & 332 & 4 & 1,989 & 22 & 596 & 7 & 2,200 & 24 & 9,010 & 100 \\
\hline 1987 & 147 & & 2,607 & 25 & 1,384 & 13 & 397 & 4 & 2,648 & 26 & 717 & 7 & 2,608 & 25 & 10,361 & 100 \\
\hline 1988 & 161 & & 2,544 & 24 & 1,452 & 14 & 406 & 4 & 2,824 & 27 & 724 & 7 & 2,563 & 24 & 10,514 & 100 \\
\hline 1989 & 161 & & 3,511 & 28 & 2,153 & 17 & 465 & 4 & 2,789 & 22 & 867 & 7 & 2,662 & 21 & 12,447 & 100 \\
\hline 1990 & 161 & & 4,504 & 32 & 2,659 & 19 & 520 & 4 & 2,854 & 20 & 807 & 6 & 2,855 & 20 & 14,198 & 100 \\
\hline
\end{tabular}

Source: "Summary of Sanitation Operations," Hiratsuka City, 1991. 
FIGURE 4-8: TRENDS IN RECYCLABLES COLLECTED - FISCAL YEARS 1985 - 1990

Thousands of tonnes

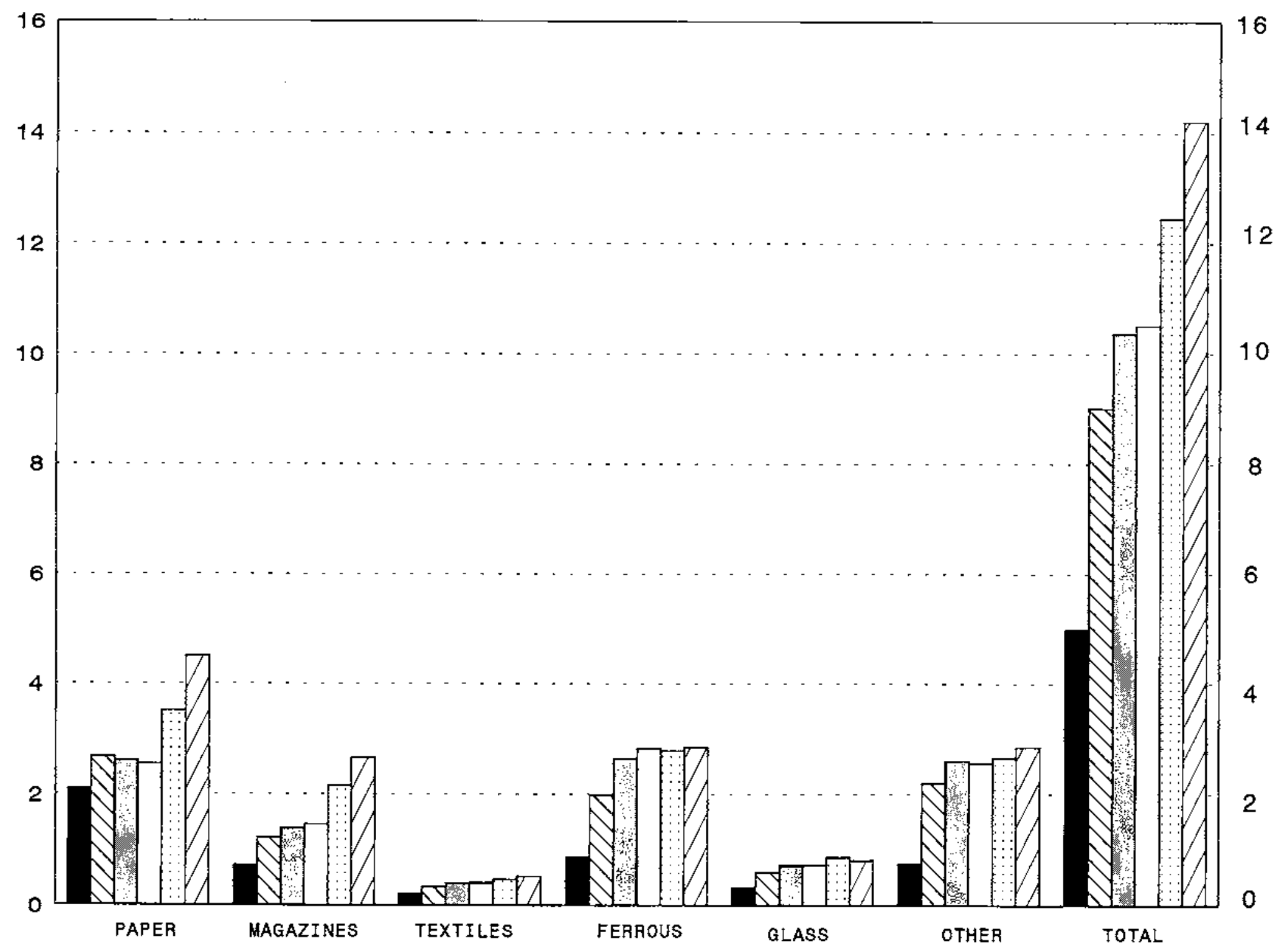


to 9,010 tonnes. This presumably reflects the increased source-separation of metals and glass from the noncombustible to the recyclable materials category by households.

In Fy90, including labor costs, the City spent about 2.7 billion yen (about $\$ 20$ million) to treat 77,160 tonnes of MSW, support the recycling groups, and recover 14,198 tonnes of materials. This amounts to a pertonne cost of about 29,000 yen (about $\$ 200$ per ton). Of this amount, 42 percent was for collection, 32 percent was for the waste-to-energy facility operations, 7 percent was for the shredding facility operations, 7 percent was for the landfill operations, and 12 percent was for the support of the recycling groups. ${ }^{76}$ The average cost to the city of the group recycling program alone was about 22,100 yen per tonne (about $\$ 150$ per ton). (Note: Care must be taken to avoid jumping to the conclusion that the City is saving money by subsidizing the group recycling activity simply because the average cost of the recycling program is less than the average cost of the total MSW treatment program. An analysis of marginal costs is required before any such conclusion can be made.)

\subsubsection{Summary and Conclusion}

The Hiratsuka Method for recovering recyclable materials from residences has been quite successful. This approach enhanced the private recycling activities that were prevalent in Hiratsuka City by fixing collection times and locations; providing subsidies to civic groups and price subsidies to recycling dealers; and organizing the collections by the recycling dealers. By doing so, the City has almost tripled the amount of material collected by the groups it supports. Unfortunately, data is not available to determine how much material was actually diverted from the MSW stream or other private recycling activities not supported by the City.

The Hiratsuka Method is an example of a highly stratified sourceseparation program. Because the materials are separated at the stations by the participants, the number of sorts is relatively large. In particular, residents are required to sort their discards into at least 15 categories, as follows: combustible, noncombustible, bulky, newspapers, magazines, milk cartons, cardboard boxes, clothing, other textiles, returnable bottles, color-sorted bottles, steel cans, aluminum cans, small appliances, and other ferrous and nonferrous metal objects such as pots and pans.

\footnotetext{
${ }^{75}$ "Separation Collections as Official Duties by Municipalities," p. 8; and "Summary of Sanitation Operations" (Fiscal Year 1991), p. 28.

${ }^{76}$ The information contained in the above-cited reference does not indicate whether these costs are gross costs or net of the national and prefectural government subsidies.
} 
This level of sorting is not as onerous as it might seem. An analogous situation in the U.S. would be buy-back or redemption centers, where individuals bring in recyclables, sort them into various categorjes, and are paid for these materials. A significant difference is that the Hiratsuka "buy back" centers, i.e., the collection stations, are located within a few blocks of any given resident's home. Also, the group recyclers, rather than the participating residents, receive payment from the city for these materials.

The success of the Hiratsuka program is apparent in that in FY90, of the 91,400 tonnes of discards ejther treated by the City or recovered through the City-supported group recycling method, 17 percent was recovered for recycling. This includes the 1,650 tonnes (i.e., 2 percent) recovered by the City from the MSW it treats and the 14,200 tonnes (i.e., 16 percent) recovered through the Hiratsuka Method. 


\section{REFERENCES}

\section{$4.1 \quad$ FUKUOKA CITY}

Council of Local Authorities for International Relations. Japan Local Government Data Book 1991. March 1992.

Environmental Bureau. Fukuoka City, Eastern Crushing Disposal Center. Environmental Bureau, September 1986.

Environmental Bureau. Fukuoka City, Eastern Refuse Incineration Plant, Second Plant. Environmental Bureau, July 1990. (English/Japanese)

Environmental Bureau. Fukuoka City, Seibu Incineration Plant. Environmental Bureau, March 1992. (English/Japanese)

Environmental Bureau. Fukuoka City, Survey of Operations. Planning Section, Department of Management, Environmental Bureau, July 1992. (Japanese)

Environmental Bureau. Fukuoka City, Tohbu (Fushitani) Reclamation Site. Environmental Bureau, undated. (English/Japanese)

Nakazato, N., Inoue, S., and Hamano, T. "Recycling Plants in Japan and the Operational Summary". Prepared for 15th National Waste Processing Conference and Exhibit, Detroit, Michigan, May 17-20, 1992. (English)

Tezuka Press, Waste Can Be a Treasure (publisher and date unknown).

\section{$4.2 \quad$ MATSUDO CITY}

Chiba Prefecture. "Guideline to Air Pollution Prevention Laws for Businesses" [Jigyōsha no tame no taiki osen bōshiho no tebiki], Chiba Prefecture Requlations, Air Pollution Prevention Section (Department of Environment, Chiba-ken, Issued May 1992). (Japanese)

Council of Local Authorities for International Relations. Japan Local Government Data Book 1991 (March 1992). (English)

Matsudo City. City Activities in Matsudo City (undated).

Matsudo City. Rules Regarding the Enforcement of Pollution Prevention Requlations - - Guidelines for Prevention of Noise Pollution in Neighboring Areas (undated). (Japanese)

Matsudo City-Survey of Cleaning Operations, [Seisō jigyō gaiyō], Fiscal Year 1991 (Matsudo City Department of Sanitation, undated). (Japanese) 
Ostrand, Inc., LTD., Matsudo City-Basic Plan for Genera] Waste Disposal (Waste Edition) [Ippan haikibutsu shori kihon keikakuj (gomihen)] (prepared for Matsudo City Department of Sanitation, March 1988). (Japanese)

Ostrand, Inc., LTD., Matsudo City - Investiqation of Weights of Household Waste: Report [Matsudo-shi katei gomi keiryo chōsa: hōkokusho], (prepared for Matsudo City Department of Sanitation, March 1987). (Japanese)

Sugiyama, Ryoko, 0strand, Inc. LTD., to ATan S. Cohen, letter, December 29,1992 .

\section{$4.3 \quad$ HIRATSUKO CITY}

Department of the Environment. Hiratsuka City, Summary of Sanitation Operations. Department of the Environment, Fiscal Year 1991. (Japanese)

Hiratsuka City. "Crushing Facility for Bulky Waste," undated brochure. (Japanese)

Hiratsuka City. "Final Disposal Site for General Waste," undated brochure. (Japanese)

Hiratsuka City. "Guidebook to Throwing Out Waste," undated brochure. (Japanese)

Hiratsuka City. "Okami Environmental Sanitation Center - - Waste Incineration Facility," undated brochure. (Japanese)

Gotoh, S., Tanaka, E., and Yonemura, Y. "Source Separation for Resource Recovery: State-of-the-Art," Conservation \& Recycling: Vol. 3; Great Britain: Pergamon Press, Ltd., 1980. (English)

"Separation Collections as Official Duties by Municipalities." (English) 


\subsection{SUMMARY OF FINDINGS}

Highlighted below are some of the salient findings of this study.

1. The underlying principal governing municial solid waste management policy in Japan is the conservation of limited landfill capacity through minimization of the volume of municipal solid waste requiring landfilling. Even though Japan has limited supplies of natural resources, its recycling efforts are driven by the need for volume reduction moreso than by the desire for materials reuse or remanufacture.

2. The environmental movement in Japan during the late 1960 s and early 1970 s was similar to the movement that occurred in the U.S. during that same time period. Comprehensive air pollution control, water pollution control, and solid waste management laws were promulgated to protect public health and the environment. An amendment to the primary solid waste disposal law and a new recycling law were passed in 1991 .

3. Conducting environmental impact assessments for large projects and employing best available control technologies is generally practiced in Japan by custom rather than through law.

4. After completion of a five-year study (1988 through 1990) of the mechanisms of formation and degredation of dioxins, the Japanese Minstry of Health and Welfare issued a set of guidelines for MSW combustion and ash disposal rather than promulgating any emission or combustion control regulations.

5. The Japanese national government has not promulgated any regulations to control heavy metal emissions from the combustion of MSW. Many local communities attempt to reduce mercury emissions by separating, at the source, materials that contain mercury, such as thermometers, dry-cell batteries, and fluorescent light bulbs.

6. Japanese municipalities often subsidize private recycling activities to increase their effectiveness and, more recently, given the decrease in market demand for recycled materials, to maintain their existence.

7. The Japanese national government provides subsidies for the construction of municipal solid waste management facilities. Such subsidies are used to implement nationally mandated environmental controls.

8. The Japanese Ministry of Health and Welfare considers combustion the most effective means of reducing the volume of and sanitizing municipal solid waste.

77 Ministry of Health and Welfare, Guidelines for Construction of Refuse Treatment Facilities (1977), p. 1 . 
9. Of the nearly 49 million tonnes of MSW (which, by definition, refers to only those discards treated by municipalities) treated during Japan's Fiscal Year 1989 (i.e., April 1, 1989, through March 31, 1990), approximately:

- 74 percent was combusted with or without energy recovery;

- 23 percent was landfilled (exclusive of ash);

- 3 percent was municipally recycled; and

- less than $1 / 10$ of one percent was composted. (The number of composting facilities has remained relatively constant over the past five years.)

10. Many discards are diverted from the MSW stream through private recycling activities and are not included in national waste generation statistics. The Japanese, in fact, refer to such diverted discards as "that which would have become waste but did not." Accounting for a11 discards, ${ }^{78}$ an estimated 55.7 to 65.5 million tonnes of residential and commercial discards were generated in Japan during FY89. Of this amount, an estimated:

- 55 to 64 percent was combusted, with and without energy recovery;

- 17 to 20 percent was landfilled (exclusive of ash); and

- 15 to 28 percent was recycled.

${ }^{78}$ Does not include that which was "self disposed" (i.e., diverted from the MSW stream through residential and commercial use of kitchen garbage disposals or sinks for disposition, or through backyard burning, burial, or composting). 
APPENDIX A

MEETINGS AND TOURS CONDUCTED IN JAPAN 
APPENDIX A

MEETINGS AND TOURS CONDUCTED IN JAPAN

MONDAY OCTOBER 12,1992

- Dr. Masaru Tanaka, Director

Department of Waste Management Engineering

The Institute of Public Health

Shiraganedai 4-6-1

Minato-ku, Tokyo

- Dr. Sukehiro Gotoh, Director

Social \& Environmental Systems Division

National Institute for Environmental Studies

Japan Environmental Agency

Prime Minister's Office

Tsukuba, Ibaraki 305

- Ms. Mayumi Yorizumi, Vice President

Community Policy Institute

International Division

9FL, 1-12-5 Sumiyoshi-Cho, Naka-ku

Yokohama 231

- Ms. Ryoko Sugiyama, Chjef Planning Engineer

Mr. Kazuo Kurihara, Planning Engineer

Ostrand Co., LTD

Waste Management Consuitants

18 Shinano-Machi

Shinjuku-ku, Tokyo 160

OCTOBER 13, 1992

- Mr. Takayoshi Miyadai, Section Head

Mr. Hidehiko Inoue, Assistant Section Head

Mr. Nobuyuki Suzuki, Assistant Section Head

Environmental Sanjtation Section

Environmental Department

9-1 Sengen-cho

Hiratsuka City 254

- Mr. Fujio Shiozaki, Assistant Section Head

Cleansing Section

1-1 Asahi-cho

Fujisawa City 251 
- Mr. Kazuhiko Hirose, Business Division

Paper Recycling Promotion Center

Ginza-0stsuka bldg. 2-16-12

Ginza, Chuo-ku, Tokyo 104

OCTOBER 14,1992

- Mr. Kaichi Sugiyama, President

Sanei Glass Co., Ltd

7-2 Asano-cho, Kawasaki-ku

Kawasaki City, Kanagawa 210

Yokahama Plant (MRF)

4-332-3 Asama-cho, Nishi-ku

Yokahama City, Yokahama 220

- Mr. Kiyoshi Saeki, Facility Maintenance Section

Machida Resource Recovery Cultural Center

Machida City, Tokyo 194-02

- Mr. Atsuhiko Sano

Sano \& Associates, Ltd.

1-12-5 Sumiyoshi-cho

Naka-ku, Yokohama 231

- Mr. Toshikiko Goto, Representative

Environmental Auditing Research Group

5-33-5 Akatsutsumi, Satagaya

Tokyo

- Mr. Masadazu Kubota, Assistant Director

Mr. Koichiro Yoshida, Staff Economist

Keidanren

1-9-4 Otemachi

Chiyoda-ku, Tokyo 100

- Mr. Satoru Morishita, Chief

Office of Marine Pollution Control \& Waste Management

Mr. Atshuiko Kimura, Deputy Director

Office of Overseas Environmental Cooperation

Mr. Kentaro Doi

Control and Cooperation Division

Mr. Tokuhisa Yoshida, Senior Technical officer

Mr. Akinori Ogawal

Office of Policy and Research

Mr. Teruyoshi Hayamizu

Water Quality Management Division

Environment Agency

Government of Japan

1-2-2 Kasumigaseki Chiyoda-ku

Tokyo 100 
OCTOBER 15, 1992

- Mr. Mitsuru Ono, Chief

Bureau of Environment

North Building of Sendai City Hall

1-1 Futsuka-machi, Aoba-ku

Senda i City, Miyagi 980-91

- Mr. Ikuo Nijzuma, President

Sendai-shi Kankyo Seibi Kousha Co., Inc.

16 Sengoku, Kozuru-aza, Miyagino-ku

Senda 1 City, Miyai 983

- Mr. Kouetsu Numata, Chief

Imaizumi Factory

Facility of Environmental Bureau of Sendai City

103 Kamishinden, Imaizumi-aza, Wakabayashi-ku

Sendai City, Miyagi 982-01

OCTOBER 15, 1992

- Mr. Nahoko Nakazawa, Assistant Manager

Overseas Environmental Planning Division

EX Corporation

OCTOBER 16, 1992

- Mr. Kazuya Yano, General Manager

Mr. Hiromsa Kamata, Assistant Manager

Aluminum Can Recycling Association

$5 \mathrm{~F}$. Ar[ Center B1dg

2-13-13 Akasaka, Minato-ku

Tokyo 107

- Mr. Masahiro Mori, Secretary General

Federation of Glass Bottle Recycling

2-37-6 Nishi Shinbashi, Minato-ku

Tokyo 105

- Mr. Masao Fujimoto, Advisor

Ms. Kazuko Ariga, officer

Clean Japan Center

No. 2 Akiyama B7dg., 3-chome 6-2 Toranomon

Minato-ku, Tokyo 105

- Mr. Akira Sato, Executive Managing Director

Mr. Masaji Shimada, Officer

Japan Used Can Treat Association

Suite 745, Kokusai Kankou Kaikan, 1-8-3 Marunocuchi

Chiyoda-ku, Tokyo 100 
OCTOBER $17, \quad 1992$

- Mr. Kunihiro Nakazato, Chief Engineer

Itoh Takuma Resource Systems Inc.

335 Madison Avenue

New York, NY 10017

OCTOBER 19, 1992

- Mr. Yasujiro Wakamura, Director/Chief Engineer

Mr. Yutaka Takeuchi, Manager

Mr. Katsumi Takaichi, Engineer

Environmental Engineering Group

Takuma Co., LTD.

3-23, Dojima Hama I-chome, Kita-ku

Osaka 530

OCTOBER 20, 1992

- Mr. Mutsumi Toyoshima, Deputy Section Head

Takuma Fukuoka office

1-11-17 Tenjin, Chuo-ku

Fukuoka City,

Mr. Keiji Shiihara, Assistant Chief

Construction Section

Environmental Bureau

Fukuoka City Hall

8-1 Tenj in 1-chome

Chuo-ku, Fukuoka City

- Mr. Mitsuyoshi Haruda, Chief

Mr. Nobuhir Takagi, Head

Mr. Muneo Inoue, Head

Facilities Department

East Garbage Plant

1799-9 Kamata, Higashi-ku

Fukuoka City 813

OCTOBER 21, 1992

- Mr. Hiroyuki Kuroda, Manager

Environmental Facility Center

52-1 Oaza-Horai

Omiya City 331

- Mr. Hideo Nakagawa, Assistant Director

Mr. Neuji Terui, Assistant Section Head

Matsudo City Garbage Reduction Section

387-5 Nemoto, Matsudo City

Chiba 271 
OCTOBER 22, 1992

- Mr. Takao Okuno, Manager

Environmental Recycling Division

Noda, Factory Manager

Ichikawa Environmental Engineering Co., Inc.

212 Kotoh-Shinden

Ichikawa City, Chiba 272-01

OCTOBER 23, 1992

- Mr. Kohki Azuma, Section Chief

Waste Management Division

Water Supply and Environmental Sanitation Department

Mininstry of Health and Welfare

1-2-2 Kasumigaseki

Tokyo $100-45$ 
APPENDIX B

GLOSSARY OF TERMS 


\author{
APPENDIX B \\ GLOSSARY OF TERMS
}

BULKY WASTE:

COMMERCIAL MSW:

DISCARDS :

DIVERSION:

GENERAL WASTE:

HOUSEHOLD HAZARDOUS WASTE:

INDUSTRIAL WASTE:
Oversized discards, including large appliances and furniture.

Municipal Solid Waste that is generated by sources other than households, including businesses (e.g., offices, restaurants, retail stores, and industry); institutions (e.g., schools and government establishments); and public areas (e.g., train stations, airports, and litter from roadside).

A11 materials that are considered used and spent by individuals or firms and are either thrown out as MSW or diverted from the MSW stream as recyclable materials.

Disposition of a discard for reuse and/or recycling rather than disposing of it through self-disposal or throwing it away as MSW, hence diverting it from the waste stream.

General Waste is defined by the Public Cleansing and Waste Disposal LaW and consists of all waste, except for radioactive wastes, that is not defined as Industrial Waste.

That portion of General Waste that is separated for collection as household hazardous waste, and usually consists of mercury-containing items such as dry-cell batteries, thermometers, and fluorescent light bulbs.

Industrial Wastes are defined by the Public Cleansing and Waste Disposal Law. These are primarily industrial process and manufacturing discards inclusive of 19 specific categories of Industrial Waste defined in the Law as provided in Table 3-5 of Section 2 of this report.

A term describing the extraction and utilization of materials from a waste stream. 
APPENDIX B (CONTINUED)

\section{GLOSSARY OF TERMS}

MUNICIPAL SOLID WASTE (MSW) :

POST-CONSUMER

MATERIALS :

RECOVERED MATERIALS:

RECYCLABLE MATERIALS OR RECYCLABLES:

RECYCLE:

RESIDENTIAL MSW:

SECONDARY MATERIAL:

SELF-DISPOSAL :
General Wastes, exclusive of sewage and septic wastes, that are treated by municipalities. MSW includes Residential MSW and Commercial MSW; it excludes industrial process wastes, agricultural wastes, mining wastes. construction and demolition debris, offal, sludges, and ashes.

Materials generated from residential and commercial discards, excluding materials from industrial processes, that have not reached the consumer, such as glass broken in the manufacturing process or unsold papers from a newspaper publisher.

Recyclable materials that are recovered from MSW which may also include some contamination.

Materials that still have useful physical or chemical properties after serving their original purpose and can, therefore, be reused or recycled for the same or other purposes.

To convert discards into useful products through reuse or remanufacturing.

Municipal solid waste that is generated by households.

A material that is used in place of a primary or raw material in manufacturing a product; often handled by dealers and brokers in "secondary markets."

The disposal or ultimate use of discarded materials in a home or business, including using of garbage disposals; pouring materials (e.g., cooking oil, spoiled milk) down the kitchen sink; burning yard waste, wood, and other combustible waste in stoves, fireplaces, or backyards; burying wastes, such as kitchen waste, in the backyard or garden; and backyard composting. 
APPENDIX B (CONTINUED)

GLOSSARY OF TERMS

SPECIALLY MANAGED WASTE:

TREATMENT :

UTILIZATION RATE:

\begin{abstract}
Specially Managed Waste is defined in the 1991 Amendment to the Public Cleansing and Waste Disposal Law and consists of General and Industrial Wastes that require special treatment or disposal because they are hazardous, explosive, toxic, infectious, or in other ways possibly detrimental to human health or the environment.
\end{abstract}

To separate, combust, compost, shred, bail, and/or physically, chemically, or biologically change the waste until it is suited for recycling or landfill disposal, inclusive of direct landfilling of the waste.

Percentage, by weight, of secondary materials used in a manufacturing process. May be measured as the percent of product produced (e.g., the ratio of the tons of cullet used to the tons of glass bottles produced, multiplied by 100 ), or as a percentage of input products $(\mathrm{e} . \mathrm{g}$. , the ratio of the tons of pulp used from secondary materials to the sum of tons of pulp used from secondary and virgin materials, muitiplied by 100). 
APPENDIX C

METRIC CONVERSION FACTORS 


\section{APPENDIX C \\ METRIC CONVERSION FACTORS}

\begin{tabular}{|c|c|c|}
\hline & METRIC UNITS & U.S. EQUIVALENTS \\
\hline \multirow[t]{3}{*}{ Length } & 1 centimeter $(\mathrm{cm})$ & 0.394 inches (in) \\
\hline & 1 meter $(m)$ & $\begin{array}{l}3.28 \text { feet }(\mathrm{ft}) \\
1.09 \text { yards }(\mathrm{yd})\end{array}$ \\
\hline & 1 kilometer $(\mathrm{km})$ & 0.621 miles (mi) \\
\hline \multirow[t]{2}{*}{ Area } & 1 square meter $\left(\mathrm{m}^{2}\right)$ & $\begin{array}{l}10.8 \text { square feet }\left(\mathrm{ft}^{2}\right) \\
1.20 \text { square yards }\left(\mathrm{yd}^{2}\right)\end{array}$ \\
\hline & 1 square kilometer $\left(\mathrm{km}^{2}\right)$ & 0.386 square miles $\left(\mathrm{mi}^{2}\right)$ \\
\hline Volume & 1 cubic meter $\left(\mathrm{m}^{3}\right)$ & $\begin{array}{l}35.3 \text { cubic feet }\left(\mathrm{ft}^{3}\right) \\
1.31 \text { cubic yards }\end{array}$ \\
\hline \multirow[t]{2}{*}{ Weight } & 1 kilogram $(\mathrm{kg})$ & $\begin{array}{l}35.3 \text { ounces }(\mathrm{oz}) \\
2.20 \text { pounds }(1 \mathrm{~b})\end{array}$ \\
\hline & $\begin{array}{l}1 \text { tonne }(\mathrm{t}) \\
(1,000 \mathrm{~kg})\end{array}$ & 1.10 tons \\
\hline Capacity & 1 liter (1) & 1.06 liquid quarts (qt) \\
\hline Concentration & $\begin{array}{l}1 \mathrm{gram} \text { per normal cubic } \\
\text { meter }\left(\mathrm{g} / \mathrm{Nm}^{3}\right)\end{array}$ & $\begin{array}{l}0.437 \text { grains per dry } \\
\text { standard cubic foot } \\
\text { (gr/dscf) }\end{array}$ \\
\hline Energy & $\begin{array}{l}1 \text { kilocalorie per } \\
\text { kilogram }(\mathrm{kcal} / \mathrm{kg})\end{array}$ & $\begin{array}{l}1.80 \text { British thermal unit } \\
\text { per pound }(B t u / l b)\end{array}$ \\
\hline
\end{tabular}


APPENDIX D

COMPARISON OF POPULATION DENSITIES: SELECTED U.S. AND JAPANESE CITIES 


\section{APPENDIX D \\ COMPARISON OF POPULATION DENSITIES: SELECTED U.S. AND JAPANESE CITIES}

1990 United States Population: 1990 Japan Population:

UNITED STATES (persons per square mile)

New York

Manhattan

Bronx

Queens

Staten Island

San Francisco

Chicago

Boston

Miami

Los Angeles

Clevel and

Seattle

6,467

15,502

12,252

11,865

10,072

7,427

6,566

6,153
$248,709,873$

$122,744,954$
JAPAN

(persons per square mile)

Tokyo

13,802

Nakano Ward

Meguro Ward

50,731

Tama District

42,623

17,352
29,536

Osaka

Yokohama

Matsudo

Nagoya

Hiratsuka

Fukuoka

Okayama
19,124

19,007

16,651

9,309

9,186

2,965 


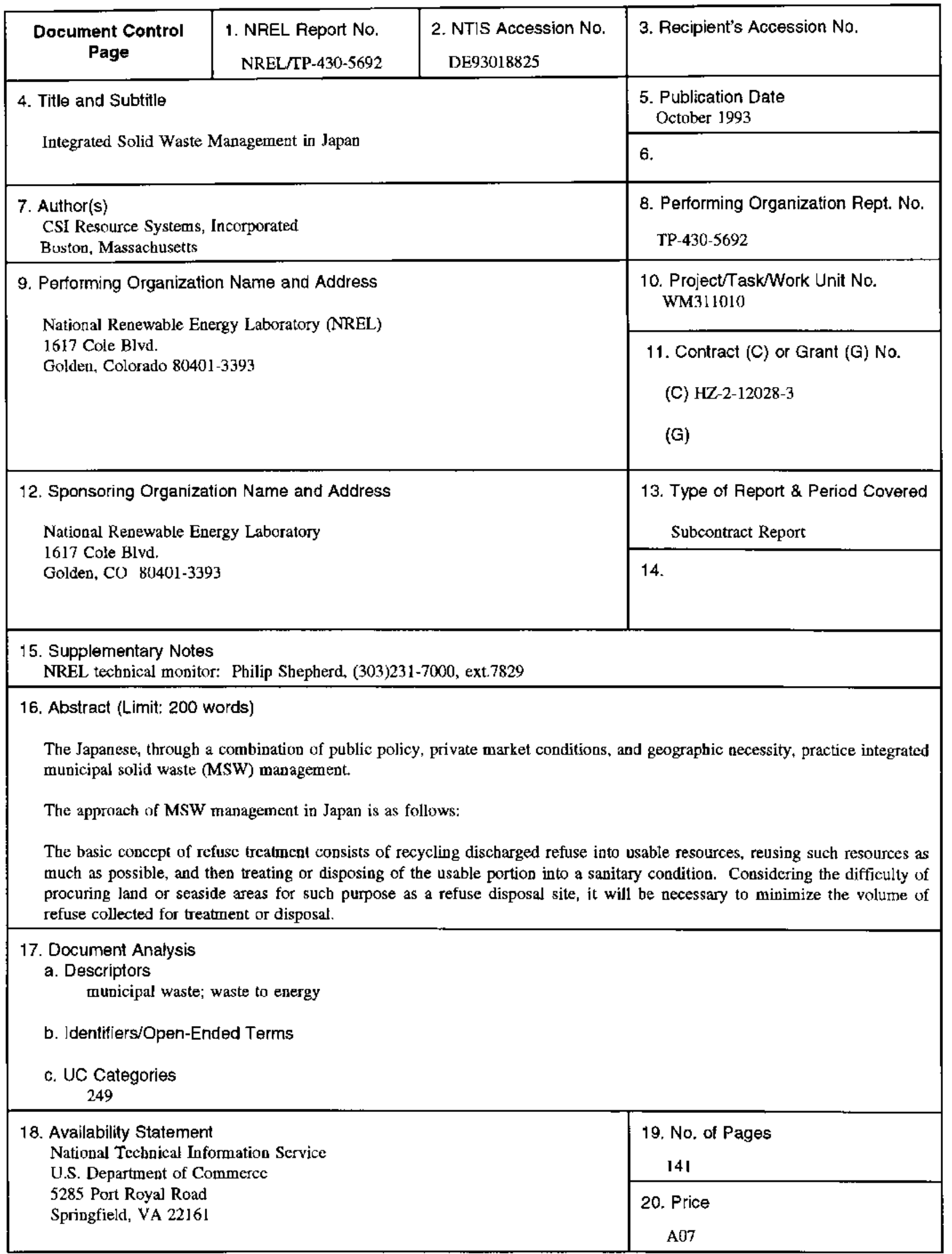

Form No. 0069E (6-30-87) 